\title{
Old and out? : age, employability, and the role of learning
}

Citation for published version (APA):

Fröhlich, D. (2015). Old and out? : age, employability, and the role of learning. [Doctoral Thesis, Maastricht University]. Datawyse / Universitaire Pers Maastricht. https://doi.org/10.26481/dis.20150902df

Document status and date:

Published: 01/01/2015

DOI:

10.26481/dis.20150902df

Document Version:

Publisher's PDF, also known as Version of record

\section{Please check the document version of this publication:}

- A submitted manuscript is the version of the article upon submission and before peer-review. There can be important differences between the submitted version and the official published version of record.

People interested in the research are advised to contact the author for the final version of the publication, or visit the DOI to the publisher's website.

- The final author version and the galley proof are versions of the publication after peer review.

- The final published version features the final layout of the paper including the volume, issue and page numbers.

Link to publication

\footnotetext{
General rights rights.

- You may freely distribute the URL identifying the publication in the public portal. please follow below link for the End User Agreement:

www.umlib.nl/taverne-license

Take down policy

If you believe that this document breaches copyright please contact us at:

repository@maastrichtuniversity.nl

providing details and we will investigate your claim.
}

Copyright and moral rights for the publications made accessible in the public portal are retained by the authors and/or other copyright owners and it is a condition of accessing publications that users recognise and abide by the legal requirements associated with these

- Users may download and print one copy of any publication from the public portal for the purpose of private study or research.

- You may not further distribute the material or use it for any profit-making activity or commercial gain

If the publication is distributed under the terms of Article $25 \mathrm{fa}$ of the Dutch Copyright Act, indicated by the "Taverne" license above, 
The research reported in this dissertation was carried out at

\section{Maastricht University}

Parts of this research were funded by Stichting A+O Metalektro.

Copyright @ 2015 Dominik E. Froehlich, Maastricht, The Netherlands

Universitaire Pers Maastricht

ISBN 978-94-6159-453-2

All rights reserved. No part of this publication may be reproduced, stored in a retrieval system, or transmitted, in any form, or by any means, electronic, mechanical, photocopying, recording or otherwise, without the prior permission in writing from the author. 


\section{Old and Out?}

Age, employability, and the role of learning

\section{DISSERTATION}

to obtain the degree of Doctor at Maastricht University, on the authority of the Rector Magnificus, Prof. dr. L. L. G. Soete in accordance with the decision of the Board of Deans, to be defended in public on Wednesday 2 September 2015, at 16.00 hours

by

Dominik Emanuel Froehlich 


\section{Supervisor}

Prof. dr. M. S. R. Segers

\section{Co-Supervisor}

Dr. S. A. J. Beausaert

\section{Assessment Committee}

Prof. dr. W. H. Gijselaers (chair)

Prof. dr. A. de Grip

Prof. dr. B. I. J. M. van der Heijden, Radboud University Nijmegen

Prof. dr. I. Raemdonck, Université catholique de Louvain 


\section{Acknowledgements}

Thank you, Mien and Simon, for having being great mentors, supporters, and sources of inspiration throughout the project.

Thank you, Jos and Martijn, for securing funds for the project and for helping to disseminate the project's findings.

Thank you, Wim, for making an otherwise rigid system flexible enough for me to fit in and to pursue this career.

Thank you, Henny, for making things work.

Thank you, study participants, contact persons, funders, and jurors of the Theodor Körner Prize, for giving me evidence that this project matters to someone.

Thank you, Ad, Darja, Hannes, Katerina, and Martijn, for being my intellectual sparring partners in Maastricht.

Thank you, Borut, Ingmar, Remy, and all colleagues at the Department for Educational Research and Development, for making my stays in Maastricht so nice.

Thank you, dear reviewers and editors, for your help in substantially increasing the value of the studies presented in this dissertation. Thank you, Anne-Katrin, Franziska, Gerhard, Regina, and Verena, for making my stays in Regensburg both fun and inspiring.

Thank you, Andreas, Beate, Gerhard, Isabel, Katalien, Maike, Martin, Ming, Piet, for allowing me to collaborate with you and to learn from you. Thank you, Jennifer, Madeline, Micha, and Sandra, for further developing the theme of this dissertation in your Master theses.

Thank you, Hubertus, Jochen, and all my friends at Toastmasters and the Global Advancement Program, for your inspiration.

Thank you, dear family and friends. This line requires no "for". 



\section{TABLE OF CONTENT}

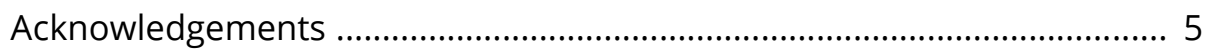

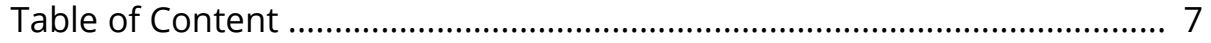

CHAPTER 1

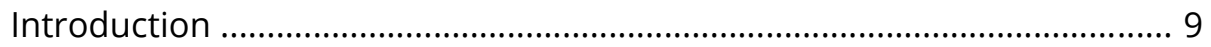

CHAPTER 2

Age, Employability, and the Role of Learning Activities and their

Motivational Antecedents: A Conceptual Model ........................................... 29

CHAPTER 3

Learning to Stay Employable 59

CHAPTER 4

Motivated to Stay Employable: The Effects of Age, Future Time

Perspective, and Goal Orientation

CHAPTER 5

Great Expectations: The Relationship between Future Time

Perspective, Informal Learning from Others, and Employability

CHAPTER 6

Feedback-Seeking in the Personal Network: The Effects on

Employability and the Perils of Homophily

CHAPTER 7

General Discussion and Directions for Future Research 169

Valorization Addendum 193

About the Author 203 

ChAPTER 1 | 9

ChAPTER 1

Introduction 
10 | INTRODUCTION 


\section{INTRODUCTION}

Changing professional demographics is a clear challenge for organizations and societies. Inevitably, people need to stay in the workforce longer to help finance the national welfare systems (Razin \& Sadka, 2005; Walker \& Maltby, 2012), to lend their expertise and experience to organizations (Midtsundstad \& Bogen, 2014; Midtsundstad, 2011), and to pay their own bills. Eventually, the proportion of older, more experienced workers in the active workforce will increase. For instance, the German car manufacturer BMW has identified the recent and ongoing demographic shift as one of the key challenges for the upcoming decades: The number of workers aged 50 and over will double between 2010 and 2020 (Anderson, 2013; BMW, 2014; Loch, Sting, Bauer, \& Mauermann, 2010). Another example of this is the German utility company RWE. For their Power division alone, they project the share of workers aged 50 and over to rise from $20 \%$ in 2008 to nearly $80 \%$ by 2018 (Strack, Baier, \& Fahlander, 2008).

At the same time, the internationalization of business and the accelerated rate of innovation are making the workplace an increasingly dynamic and competitive environment. Given that fact, how does the aging workforce fit into the affordances of such an environment? Contemporary workplaces are often unfriendly environments for older workers. For example, older employees are disproportionally more often subject to layoffs during restructuring periods (Kim \& Mo, 2014), negative stereotypes (Iweins, Desmette, Yzerbyt, \& Stinglhamber, 2013; John, 2013; Posthuma \& Campion, 2009), and difficulties finding jobs (Ahmed, Andersson, \& Hammarstedt, 2012; Albert, Escot, \& Fernández-Cornejo, 2011). This questions older employees' employability, the competence to continuously fulfill and acquire work for themselves (Van der Heijde \& Van der Heijden, 2006). However, with organizations becoming more and more dependent on older workers, namely due to their knowledge and skills, managers need to rethink their human resource policies concerning age. Employable employees, irrespective of their age, are a vital resource for business success (Van der Heijde \& Van der Heijden, 2006).

Employable employees have a set of competences that enables them to fulfill, acquire, or create work (Van der Heijde \& Van der Heijden, 2006). These competences include expertise, adaptability to change, active 
monitoring of the work environment, balance between employee and employer interests, and identification with the employing organization. That being said, how can employability be sustained in advanced ages? Defining employability as a set of competences (Van der Heijde \& Van der Heijden, 2006) indicates that employees' employability is dynamic and may be developed by engaging in learning activities. Indeed, previous work does indicate that learning activities may enhance individuals' employability (Van der Heijden, Boon, Van der Klink, \& Meijs, 2009); however, evidence for this relationship is still scarce (De Vos, De Hauw, \& Van der Heijden, 2011).

In this dissertation, we expand upon previous work by focusing on the attributes and activities of individual employees. Specifically, we research how chronological age, motivation, and learning activities explain older employees' employability. By taking a learning perspective, we effectively consider future time perspective (Lang \& Carstensen, 2002), goal orientation (Elliot \& McGregor, 2001), and activities of formal learning and informal learning from others. This focus on psychological and behavioral learning-related factors provides alternative explanations of how employability is shaped during the aging process and extends current models (e.g., Van der Heijden, De Lange, Demerouti, \& Van der Heijde, 2009).

Assuming a direct relationship between age and employability - as suggested by the higher unemployment rates for older age groups (European Commission, 2010) - may be overly simplistic and offers little guidance on how older workers can remain employable. Current research, however, has not paid sufficient attention to potential mediators of the relationship between age and employability. Essentially, despite the practical urgency and importance of the topic, we lack the necessary knowledge to give advice on how to manage employees in order to sustain their employability as they age.

\section{THEORETICAL FRAMEWORK}

In this dissertation, we take a learning perspective and propose the research model shown in Figure 1. We research the relationship between chronological age and employability and study the mediating role of 
motivation and learning activities. In this section, we briefly introduce the major concepts used in this dissertation.

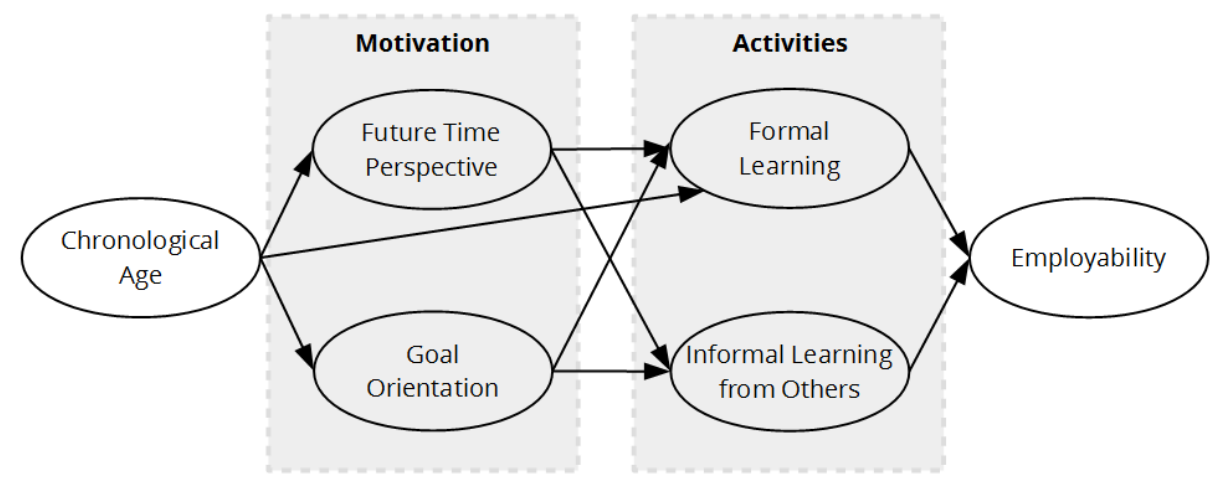

Figure 1: Research model of this dissertation.

\section{Employability}

Employability research can be clustered into three phases (Gazier, 2001). Early in the $20^{\text {th }}$ century, researchers based the definition of employability on whether one was able and willing to work. In the middle of the $20^{\text {th }}$ century, research began to consider the labor market demand. At the end of the $20^{\text {th }}$ century, employability research became more holistic and focused on labor market outcomes, individuals' responsibility to develop transferable skills due to increasingly inter-organizational careers, and employability's relativity in terms of supply and demand on the labor market. In sum, the concept has been regularly adapted to specific labor market situations at specific times in history.

Today, the accelerating rate of innovation makes it necessary to focus on individuals' attributes, rather than on volatile labor market demands. Therefore, we define being employable as having a set of competences that enables people to fulfill, acquire, or create work (Van der Heijde \& Van der Heijden, 2006). This includes technical expertise, but also more generic social and adaptive competences (Rodriguez, Patel, Bright, Gregory, \& Gowing, 2002). More specifically, Van der Heijde and Van der Heijden (2006) state that proactive, self-initiated screening and preparation for potential changes in job and career requirements and conditions 
(anticipation and optimization), as well as reactive adaptation and resilience to those conditions (personal flexibility), are required. Additionally, identification with the organization's goals and the ability to work together with others are needed (corporate sense). Balance, the ability to appropriately weigh employer interests against personal interests, was identified as another key competence of employability. Possession of these four generic competences, in addition to one's job-specific occupational expertise, should enhance an employee's potential to fulfill, acquire, or create work.

\section{Age}

Different perspectives of age inevitably exist (Diehl et al., 2014; Schalk et al., 2010). For instance, age may be based on the ability of a person to perform certain tasks (functional age; Sharkey, 1987), a subjective feeling (psychological age; Stephan, Demulier, \& Terracciano, 2012), tenure (organizational age), biological and societal factors and the roles people take during their lives (life-span age; Schulz \& Heckhausen, 1996), or the time passed since birth (chronological age).

Chronological age is by far the most prominent conceptualization of age in employability research. Many studies include it in their analyses and find negative relationships between age and employability (De Cuyper, Mauno, Kinnunen, \& Mäkikangas, 2011; Nauta, De Vroome, Cox, Korver, \& Kraan, 2005; Raemdonck, Tillema, Grip, Valcke, \& Segers, 2012; Rothwell \& Arnold, 2007; Van der Heijden, 2002; Van Vuuren, Caniels, \& Semeijn, 2011; Wittekind, Raeder, \& Grote, 2010). However, it is unclear how these findings can be interpreted, because chronological age combines many changes related to aging, many of which are difficult to disentangle. For instance, physical and mental changes, stereotypes of others, effects of the time period, or the cohort itself can all have significant effects (Hall, Mairesse, \& Turner, 2007). Another problem is that older people are not a homogeneous group. The older people get and the more experience they accumulate, the more heterogeneous they become (Bal, Kooij, \& Rousseau, 2015; Staudinger \& Bowen, 2011). This puts the predictive value of chronological age into question. Additionally, no practical implications can be given to individuals, as one's chronological age cannot be changed. In this dissertation, we 
provide a conceptual framework to study the relationship between chronological age and employability in greater detail. We question the central role of chronological age in past research and public debate and instead propose a model that considers employees' motivation and learning activities.

\section{Learning activities}

Both activities of formal learning and informal learning from others may help to develop the necessary competences to remain employable. Formal learning includes all of the learning inside a structure deliberately created for that purpose (CEDEFOP, 2008). For instance, this includes attending seminars and workshops or following courses offered by an educational institution. Informal learning is less pre-structured, more controlled by the learner, embedded in daily working activities, and may happen unconsciously (cf. Livingstone, 2001; Marsick \& Watkins, 2001). Often, learning is not the primary purpose of the activity; its outcomes are not defined in advance (Kock \& Ellström, 2011). For example, informal learning includes activities such as ad-hoc exchanges with others or learning by doing. While the learning is undertaken autonomously (Kyndt \& Baert, 2013), organizations and managers are still influential in terms of how much they support it (Froehlich, Segers, \& Van den Bossche, 2014; Kyndt, Dochy, \& Nijs, 2009).

Previous research suggests that informal learning from others is a major part of work-related learning (Boud \& Middleton, 2003; Eraut, 2007; Tannenbaum, Beard, McNall, \& Salas, 2010). Employees that utilize and consult their social network while working may be better prepared to perform their work more effectively (Borgatti \& Cross, 2003). Therefore, we focus on informal learning from others in this dissertation. This entails the proactive search for information, feedback, and help from others at the workplace (Bamberger, 2009; Froehlich, Beausaert, \& Segers, 2015). Helpseeking is the proactive search for assistance from others to solve a specific problem (Karabenick \& Newman, 2006; Karabenick, 1998). Feedback-seeking is the proactive search for information targeted at evaluating and reflecting upon work processes and the self (Anseel, Lievens, \& Levy, 2007; Van den Bossche, Van Waes, \& Van der Rijt, 2013). Information-seeking is not aimed 
at solving a specific problem, like help-seeking, nor does it contain an evaluative component like feedback-seeking. At least, it is not originally performed for these purposes, although the information may eventually serve as a basis for tackling a specific problem or evaluating oneself.

Formal learning and informal learning are not mutually exclusive (Kyndt \& Baert, 2013). Therefore, we consider both formal learning and informal learning from others simultaneously, but separately.

\section{Motivation}

We draw from two theories of motivation that have previously been linked to both age and learning and competence development: socioemotional selectivity theory (Carstensen, 2006) and goal orientation theory (Elliot \& McGregor, 2001). Socioemotional selectivity theory posits that individuals select and pursue their goals in alignment with their (working) life's time horizon, called future time perspective (Carstensen, Isaacowitz, \& Charles, 1999). This perspective affects the motivation to learn and perform (Raemdonck, Beausaert, Froehlich, Kochoian, \& Meurant, 2015). For example, employees that see themselves as approaching retirement are less inclined to grow and invest in their career. Instead, they may focus on emotional goals, such as spending time with their friends at work (cf. Lang \& Carstensen, 2002).

Goal orientation theory studies how people define, approach, and respond to achievement situations (Brett \& VandeWalle, 1999; Van Dierendonck \& Van der Gaast, 2013). Goal orientations are a set of beliefs and attributions that affect the manner with which such situations are dealt. For instance, employees may feel that it is hard to keep up with current trends. Instead of attempting to master them, they focus on presenting themselves in a favorable light. For example, they may focus on delivering good work and on communicating it effectively. Previous studies have indicated that especially older people are more oriented towards maintaining their status (Ebner, Freund, \& Baltes, 2006; Ogilvie, Rose, \& Heppen, 2010) and show a distinct decrease in growth motives (Kooij, De Lange, Jansen, Kanfer, \& Dikkers, 2011). 


\section{OVERVIEW OF THE STUDIES}

We present five studies in this dissertation, and each deals with a distinct part of the research model. The dissertation concludes with an overall summary and discussion (Chapter 7) and a valorization addendum.

In Chapter 2 we discuss the elements of the framework presented in Figure 1 in detail. We develop a model of how motivation and learning activities help to sustain older employees' employability. While age is a central theme of this dissertation, we do not focus on older workers exclusively, as this would require an arbitrary definition of what "old age" is. While some previous research has used varying threshold levels (e.g., 45 years (Billett, 2011; Fournier, Zimmermann, \& Gauthier, 2011)), we take a different approach. We include age as a continuous variable in the research model. The results of this chapter will be used to guide further empirical work, which is presented in Chapters 3 to 6 .

In the empirical study presented in Chapter 3 we aim to examine the effects of chronological age and activities of formal learning and informal learning from others on employability. Furthermore, we test indirect effects of age on employability via learning activities (see Figure 2 ). We conducted quantitative, cross-sectional survey research $(n=780)$ in three Dutch and Austrian organizations to study the relationship between chronological age, learning activities, and employability using hierarchical multiple regression analyses and mediation analyses.

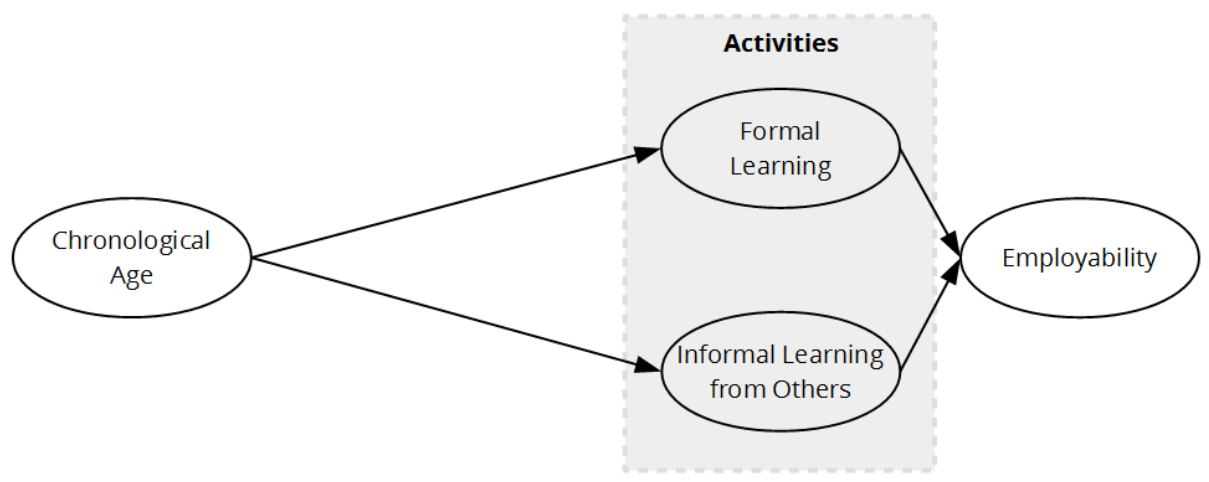

Figure 2: Research model of Chapter 3. 
In Chapter 4, we present an empirical study in which we investigate the effects of age, future time perspective, and goal orientation on employability. We conducted quantitative, cross-sectional survey research ( $\mathrm{n}$ $=282$ ) in three Dutch and Austrian organizations. We used structural equation modeling to also test for indirect effects of age (see Figure 3 ).

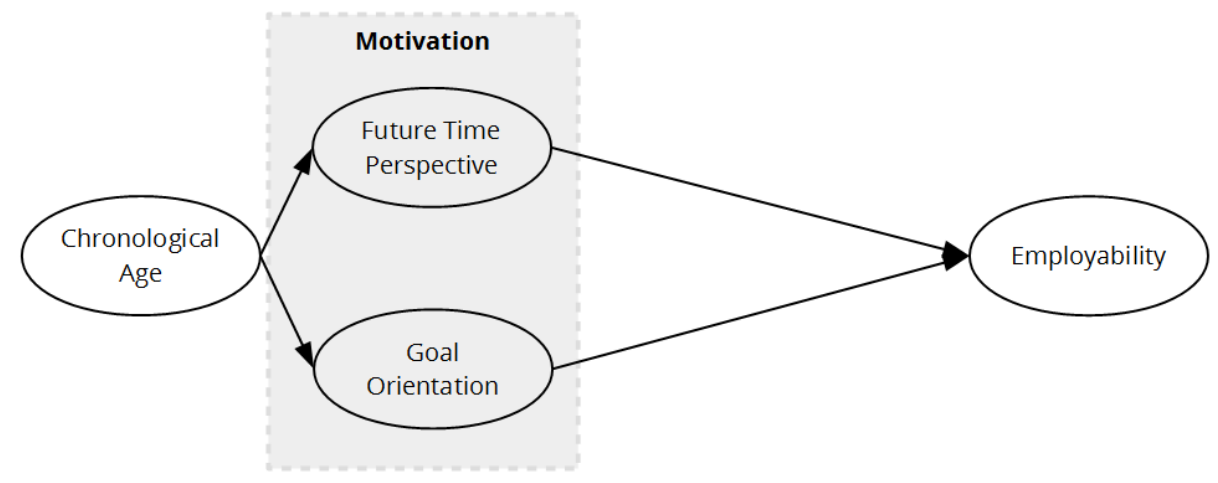

Figure 3: Research model of Chapter 4.

The findings of the preceding studies show the effects of motivation and learning activities. However, we did not investigate these concepts and their relationship with employability simultaneously. This analysis is done in Chapter 5. Specifically, we investigate how employees' perception of the future as a time of opportunities and limitations affects their engagement in informal learning from others and, in turn, their employability (see Figure 4). We tested our model empirically in two Austrian consultancies $(n=167)$. 


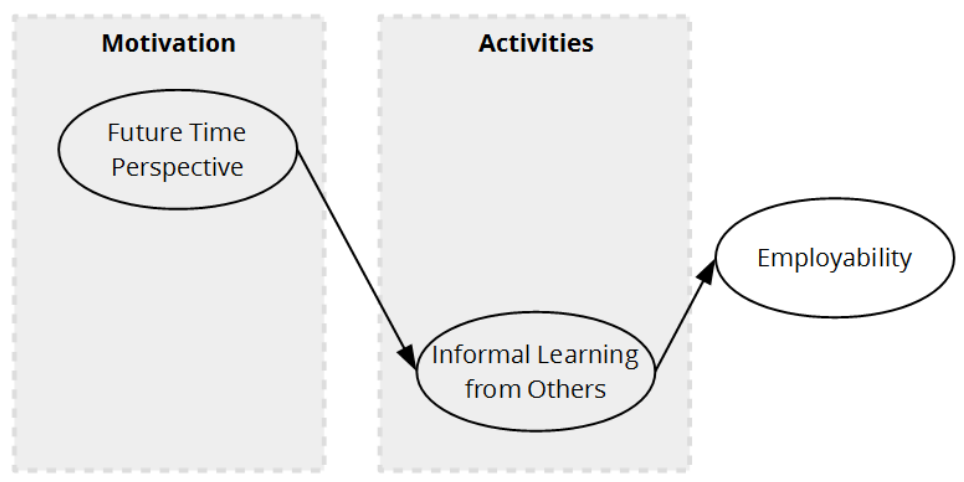

Figure 4: Research model of Chapter 5.

In Chapter 6, we conduct social network analyses of six samples to study the relationship between informal learning from others and employability in detail (see Figure 5). We investigate 1,948 feedback-seeking relationships of 107 employees in Austria, India, and the Netherlands and study how homophily affects the composition of feedback-seeking networks at work and how the composition of these feedback-seeking networks influences employees' employability.

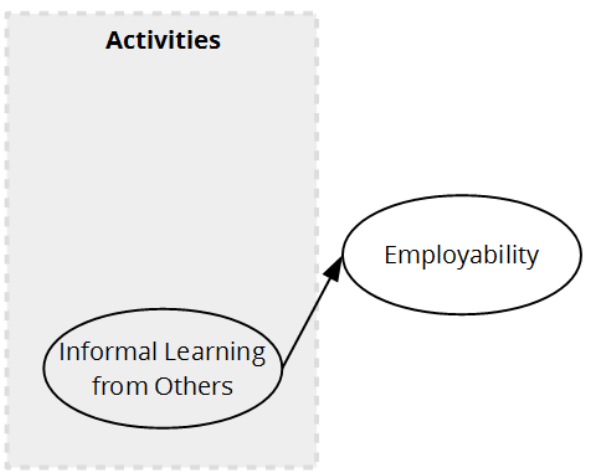

Figure 5: Research model of Chapter 6.

\section{NOTES}

Note that this dissertation is a collection of related articles, rather than a monograph. Since each chapter may be read on its own, repetitions and overlap across chapters are inevitable. Additionally, minor adaptations 
were made to the published articles included in this dissertation, in order to improve consistency. Since the articles have been published or are about to be published in different fields of research, some terms could not be used consistently throughout the manuscript. When we refer to (learning) activities, we mean informal learning from others by seeking information, feedback, and help (unless specified otherwise). 


\section{REFERENCES}

Ahmed, A. M., Andersson, L., \& Hammarstedt, M. (2012). Does age matter for employability? A field experiment on ageism in the Swedish labour market. Applied Economics Letters, 19(4), 403-406. doi:10.1080/13504851.2011.581199

Albert, R., Escot, L., \& Fernández-Cornejo, J. A. (2011). A field experiment to study sex and age discrimination in the Madrid labour market. International Journal of Human Resource Management, 22(2), 351-375. doi:10.1080/09585192.2011.540160

Anderson, L. B. (2013). How frames present BMW as embracing an aging workforce. Public Relations Review, 39(5), 484-490. doi:10.1016/j.pubrev.2013.02.003

Anseel, F., Lievens, F., \& Levy, P. E. (2007). A Self-motives Perspective on Feedback-seeking Behavior: Linking Organizational Behavior and Social Psychology Research. International Journal of Management Reviews, 9(3), 211-236. doi:10.1111/j.1468-2370.2007.00210.x

Bal, P. M., Kooij, D. T. A. M., \& Rousseau, D. M. (2015). Conclusion and Future Research. In P. M. Bal, D. T. A. M. Kooij, \& D. M. Rousseau (Eds.), Aging Workers and the Employee-Employer Relationship (pp. 261-268). Cham: Springer Netherlands. doi:10.1007/978-3-319-08007-9_15

Bamberger, P. A. (2009). Employee Help-Seeking: Antecedents, Consequences and new Insights for Future Research. In J. J. Martocchio \& H. Liao (Eds.), Research in Personnel and Human Resource Management (Vol. 28, pp. 49-98). Bingley: Emerald Group Publishing. doi:10.1108/S0742-7301(2009)0000028005

Billett, S. (2011). Promoting Lifelong Employability for Workforce Aged Over 45: Singaporean Workers' Perspectives. International Journal of Continuing Education and Lifelong Learning, 3(2), 57-73.

BMW. (2014). Sustainable Value Report 2013. Munich: BMW.

Borgatti, S. P., \& Cross, R. (2003). A Relational View of Information Seeking and Learning in Social Networks. Management Science, 49(4), 432-445. 
Boud, D., \& Middleton, H. (2003). Learning from others at work: communities of practice and informal learning. Journal of Workplace Learning, 15(5), 194-202. doi:10.1108/13665620310483895

Brett, J. F., \& VandeWalle, D. (1999). Goal orientation and goal content as predictors of performance in a training program. Journal of Applied Psychology, 84(6), 863-873. doi:10.1037//0021-9010.84.6.863

Carstensen, L. L. (2006). The Influence of a Sense of Time on Human Development. Science, 312(5782), 1913-1915. doi:10.1126/science.1127488

Carstensen, L. L., Isaacowitz, D. M., \& Charles, S. T. (1999). Taking Time Seriously: A Theory of Socioemotional Selectivity. American Psychologist, 54(3), 165-181. doi:10.1037/0003-066X.54.3.165

CEDEFOP. (2008). Terminology of European education and training policy. Luxembourg: Office for Official Publications of the European Communities.

De Cuyper, N., Mauno, S., Kinnunen, U., \& Mäkikangas, A. (2011). The role of job resources in the relation between perceived employability and turnover intention: A prospective two-sample study. Journal of Vocational Behavior, 78(2), 253-263. doi:10.1016/j.jvb.2010.09.008

De Vos, A., De Hauw, S., \& Van der Heijden, B. I. J. M. (2011). Competency development and career success: The mediating role of employability. Journal of Vocational Behavior, 79(2), 438-447. doi:10.1016/j.jvb.2011.05.010

Diehl, M., Wahl, H.-W., Barrett, A. E., Brothers, A. F., Miche, M., Montepare, J. M., ... Wurm, S. (2014). Awareness of aging: Theoretical considerations on an emerging concept. Developmental Review. doi:10.1016/j.dr.2014.01.001

Ebner, N. C., Freund, A. M., \& Baltes, P. B. (2006). Developmental changes in personal goal orientation from young to late adulthood: from striving for gains to maintenance and prevention of losses. Psychology and Aging, 21(4), 664-678. doi:10.1037/0882-7974.21.4.664

Elliot, A. J., \& McGregor, H. A. (2001). A 2x2 Achievement Goal Framework. Journal of Personality and Social Psychology, 80(3), 501-519. 
Eraut, M. (2007). Learning from Other People in the Workplace. Oxford Review of Education, 33(4), 403-422. doi:10.1080/03054980701425706

European Commission. (2010). Employment in Europe 2010. Luxembourg: Publications Office of the European Union. doi:10.2767/72770

Fournier, G., Zimmermann, H., \& Gauthier, C. (2011). Instable career paths among workers 45 and over: Insight gained from long-term career trajectories. Journal of Aging Studies, 25(3), 316-327. doi:10.1016/j.jaging.2010.11.003

Froehlich, D. E., Beausaert, S. A. J., \& Segers, M. S. R. (2015). Employees' conceptions of proactive informal learning from others. Paper presented at the 16th biennial EARLI conference for research on learning and instruction. Limassol.

Froehlich, D. E., Segers, M. S. R., \& Van den Bossche, P. (2014). Informal Workplace Learning in Austrian Banks: The Influence of Learning Approach, Leadership Style, and Organizational Learning Culture on Managers' Learning Outcomes. Human Resource Development Quarterly, 25(1), 29-57. doi:10.1002/hrdq.21173

Gazier, B. (2001). Employability: the complexity of a policy notion. In P. Weinert, M. Baukens, P. Bóllerot, M. Pineschi-Gapénne, \& U. Walwei (Eds.), Employability: From Theory to Practice (pp. 3-23). New Brunswick, $\mathrm{NJ}$ : Transaction Books.

Hall, B. H., Mairesse, J., \& Turner, L. (2007). Identifying age, cohort, and period effects in scientific research productivity: discussion and illustration using simulated and actual data on french physicists. Economics of Innovation and New Technology, 16(2), 37-41.

Iweins, C., Desmette, D., Yzerbyt, V., \& Stinglhamber, F. (2013). Ageism at work: The impact of intergenerational contact and organizational multiage perspective. European Journal of Work and Organizational Psychology, 22(3), 331-346. doi:10.1080/1359432X.2012.748656

John, B. (2013). Patterns of Ageism in Different Age Groups. Journal of European Psychology Students, 4, 16-36.

Karabenick, S. A. (1998). Strategic Help-seeking: Implications for Learning and Teaching. Mahwah: Erlbaum. 
Karabenick, S. A., \& Newman, R. S. (2006). Help Seeking in Academic Settings: Goals, Groups, and Contexts. Mahwah: Erlbaum.

Kim, D. S., \& Mo, S. H. (2014). Stereotypical Beliefs on Old Korean Workers. Ageing International. doi:10.1007/s12126-014-9200-4

Kock, H., \& Ellström, P.-E. (2011). Formal and integrated strategies for competence development in SMEs Formal and Integrated Strategies. Journal of European Industrial Training, 35(1), 71-88.

Kooij, D. T. A. M., De Lange, A. H., Jansen, P. G. W., Kanfer, R., \& Dikkers, J. S. E. (2011). Age and Work-related Motives: Results of a Meta-analysis. Journal of Organizational Behavior, 32(1), 197-225. doi:10.1002/job

Kyndt, E., \& Baert, H. (2013). Antecedents of Employees' Involvement in Work-Related Learning: A Systematic Review. Review of Educational Research, 83(2), 273-313. doi:10.3102/0034654313478021

Kyndt, E., Dochy, F., \& Nijs, H. (2009). Learning Conditions for Non-Formal and Informal Workplace Learning. Journal of Workplace Learning, 21(5), 369-383. doi:10.1108/13665620910966785

Lang, F. R., \& Carstensen, L. L. (2002). Time counts: Future time perspective, goals, and social relationships. Psychology and Aging, 17(1), 125-139. doi:10.1037//0882-7974.17.1.125

Livingstone, D. W. (2001). Adults' Informal Learning: Definitions, Findings, Gaps and Future Research (No. 21). Toronto, Ontario: Centre for the Study of Education and Work.

Loch, C. H., Sting, F. J., Bauer, N., \& Mauermann, H. (2010). How BMW Is Defusing the Demographic Time Bomb. Harvard Business Review, (3), 99-102.

Marsick, V. J., \& Watkins, K. E. (2001). Informal and Incidental Learning. New Directions for Adult and Continuing Education, 2001(89), 25-34. doi:10.1002/ace.5

Midtsundstad, T. I. (2011). Inclusive workplaces and older employees: an analysis of companies' investment in retaining senior workers. International Journal of Human Resource Management, 22(6), 1277-1293. doi:10.1080/09585192.2011.559099 
Midtsundstad, T. I., \& Bogen, H. (2014). Active Aging Policies between Individual Needs and Collective Goods. A Study of Active Aging Policies and Practices in Norway. Nordic Journal of Working Life Studies, 4(2), 139-158.

Nauta, A., De Vroome, E., Cox, E., Korver, T., \& Kraan, K. (2005). De invloed van functietype op het verband tussen leeftijd en inzetbaarheid [The influence of function type on the relationship between age and employability]. Gedrag \& Organisatie, 18(6), 326-337.

Ogilvie, D. M., Rose, K. M., \& Heppen, J. B. (2010). A Comparison of Personal Project Motives in Three Age Groups. Basic and Applied Social Psychology, 23(3), 207-215.

Posthuma, R. a., \& Campion, M. A. (2009). Age Stereotypes in the Workplace: Common Stereotypes, Moderators, and Future Research Directions. Journal of Management, 35(1), 158-188. doi:10.1177/0149206308318617

Raemdonck, I., Beausaert, S. A. J., Froehlich, D. E., Kochoian, N., \& Meurant, C. (2015). Age related changes in learning and employability. In D. Rosseau, D. T. A. M. Kooij, \& P. M. Bal (Eds.), Aging Workers and the Employee-Employer Relationship (pp. 163-184).

Raemdonck, I., Tillema, H. H., Grip, A., Valcke, M., \& Segers, M. S. R. (2012). Does Self-directedness in Learning and Careers Predict the Employability of Low-Qualified Employees? Vocations and Learning, 5(2), 137-151. doi:10.1007/s12186-011-9072-7

Razin, A., \& Sadka, E. (2005). The Decline of the Welfare State. Cambridge, MA: MIT Press.

Rodriguez, D., Patel, R., Bright, A., Gregory, D., \& Gowing, M. K. (2002). Developing competency models to promote integrated human resource practices. Human Resource Management, 41(3), 309-324. doi:10.1002/hrm.10043

Rothwell, A., \& Arnold, J. (2007). Self-perceived employability: Development and validation of a scale. Personnel Review, 36(1), 23-41. doi:10.1108/00483480710716704

Schalk, R., Van Veldhoven, M. J. P. M., De Lange, A. H., De Witte, H., Kraus, K., Stamov-Roßnagel, C., ... Zacher, H. (2010). Moving European Research 
on Work and Ageing Forward: Overview and Agenda. European Journal of Work and Organizational Psychology, 19(1), 76-101. doi:10.1080/13594320802674629

Schulz, R., \& Heckhausen, J. (1996). A life span model of successful aging. The American Psychologist, 51(7), 702-714.

Sharkey, B. J. (1987). Functional vs chronologic age. Medicine and Science in Sports and Exercise, 19(2), 174-178.

Staudinger, U. M., \& Bowen, C. E. (2011). A systemic approach to aging in the work context. Zeitschrift für ArbeitsmarktForschung, 44(4), 295-306. doi:10.1007/s12651-011-0086-2

Stephan, Y., Demulier, V., \& Terracciano, A. (2012). Personality, self-rated health, and subjective age in a life-span sample: The moderating role of chronological age. Psychology and Aging, 27(4), 875-880. doi:10.1037/a0028301

Strack, R., Baier, J., \& Fahlander, A. (2008). Managing Demographic Risk. Harvard Business Review, (2), 119-129.

Tannenbaum, S. I., Beard, R. L., McNall, L. A., \& Salas, E. (2010). Informal learning and development in organizations. In S. W. J. Kozlowski \& E. Salas (Eds.), Learning, training, and development in organizations (pp. 303-331). New York: Routledge Taylor \& Francis Group.

Van den Bossche, P., Van Waes, S., \& Van der Rijt, J. (2013). Feedback, Development, and Social Networks. In K. Kraiger, J. Passmore, N. R. dos Santos, \& S. Malvezzi (Eds.), The Wiley Blackwell Handbook of the Psychology of Training, Development, and Performance Improvement. Wiley.

Van der Heijde, C. M., \& Van der Heijden, B. I. J. M. (2006). A competencebased and multidimensional operationalization and measurement of employability. Human Resource Management, 45(3), 449-476. doi:10.1002/hrm.20119

Van der Heijden, B. I. J. M. (2002). Prerequisites to guarantee life-long employability. Personnel Review, 31(1), 44-61. doi:10.1108/00483480210412418 
Van der Heijden, B. I. J. M., Boon, J., Van der Klink, M. R., \& Meijs, E. (2009). Employability Enhancement through Formal and Informal Learning: An Empirical Study among Dutch Non-Academic University Staff Members. International Journal of Training and Development, 13(1), 19-37. doi:10.1111/j.1468-2419.2008.00313.x

Van der Heijden, B. I. J. M., De Lange, A. H., Demerouti, E., \& Van der Heijde, C. M. (2009). Age Effects on the Employability-Career Success Relationship. Journal of Vocational Behavior, 74(2), 156-164. doi:10.1016/j.jvb.2008.12.009

Van Dierendonck, D., \& Van der Gaast, E. (2013). Goal orientation, academic competences and early career success. Career Development International, 18(7), 694-711. doi:10.1108/CDI-01-2013-0003

Van Vuuren, T., Caniels, M. C. J., \& Semeijn, J. H. (2011). Duurzame inzetbaarheid en een leven lang leren [Sustainable employability and lifelong learning]. Gedrag \& Organisatie, 24(4), 356-373.

Walker, A., \& Maltby, T. (2012). Active ageing: A strategic policy solution to demographic ageing in the European Union. International Journal of Social Welfare, 21, S117-S130. doi:10.1111/j.1468-2397.2012.00871.x

Wittekind, A., Raeder, S., \& Grote, G. (2010). A Longitudinal Study of Determinants of Perceived Employability. Journal of Organizational Behavior, 31(4), 566-586. doi:10.1002/job.646 
28 | INTRODUCTION 


\section{CHAPTER 2}

\section{Age, Employability, and the Role of Learning Activities and their Motivational Antecedents: A Conceptual Model ${ }^{*}$}

* This chapter is based on: Froehlich, D. E., Beausaert, S. A. J., \& Segers, M. S. R. (2014). Age, employability and the role of learning activities and their motivational antecedents: a conceptual model. International Journal of Human Resource Management, 1-15. doi:10.1080/09585192.2014.971846

Froehlich, D. E., Beausaert, S. A. J., \& Segers, M. S. R. (2012). Old and Out? A social network approach towards age, self-responsibility, and their effects on employability. Paper presented at the EARLI SIG 14. Antwerp. 


\section{Abstract}

In today's time of demographic change and rapid innovation, age and employability as well as the role of learning and development are high on the agenda of human resource managers and Chief Learning Officers. However, existing research has failed to integrate these concepts in a clear model and offers little explanation of how the concepts may be linked exactly. In this conceptual chapter, we show how chronological age, despite its poor characteristics as a predictor, might still affect employability indirectly. Specifically, we propose that employees' motivation - in terms of future time perspective and goal orientation - and formal and informal learning activities need to be considered. Since an individual's chronological age cannot be changed, it is important to recognize these mediating variables, which may be targeted more easily by human resource development or age management initiatives. 


\section{INTRODUCTION}

The populations of many countries are aging and a reversal of this trend seems unlikely (OECD, 2012). Inevitably, people need to stay longer in the workforce: to sustain national welfare systems, to help organizations thrive, and to pay their own bills. Consequently, governments all over the world revise their retirement policies to encourage longer working lives (Billett, 2011) - for instance, the changed Default Retirement Age in Great Britain (Department for Business Innovation and Skills, 2011). Similarly, organizations adapt their employment and retention policies (Colley, 2013) to combat the brain drain caused by the large number of senior workers retiring in the upcoming five to ten years and to keep on top of the ever increasing pace of innovation and changing demands. Eventually, the proportion of older, experienced workers in the active workforce will increase. This puts employability on the agenda of both politics and business. Governments seek to maintain the social welfare systems and call for better integration of older people in the active workforce (Razin \& Sadka, 2005; Walker \& Maltby, 2012). Businesses struggle to retain and attract experienced employees (Midtsundstad \& Bogen, 2014; Midtsundstad, 2011).

Employability means the "continuous fulfilling, acquiring or creating of work [by employees] through the optimal use of competences" (Van der Heijde \& Van der Heijden, 2006, p. 435). Employable employees identify and realize career opportunities (Fugate, Kinicki, \& Ashforth, 2004). To do so, they need diverse competences such as expertise, adaptability to changes, active monitoring of the work environment, balance between employee and employer interests, and identification with the employing organization (Van der Heijde \& Van der Heijden, 2006).

Despite the pivotal importance of lifelong employability, we still do not sufficiently understand how it can be sustained in higher ages. It is argued that learning activities are needed to develop competences and, in turn, improve individuals' employability (Van der Heijden, Boon, Van der Klink, \& Meijs, 2009) and careers (Maurer \& Chapman, 2013). However, research on the relationship between learning and employability is scarce (De Vos, De Hauw, \& Van der Heijden, 2011). Moreover, to the best of our knowledge, no existing model of employability explicitly discusses the effects of chronological age (cf. Clarke, 2008). The physical and mental 
changes during the process of aging (e.g., Bassey, 1998; Schaie, 1984) and the stereotypes about older workers (Malinen \& Johnston, 2013), however, can hardly be ignored (Ilmarinen, 2001; Segal, Qualls, \& Smyer, 2011).

Assuming a direct relationship between age and employability - as often suggested by the higher unemployment rates for older age groups (European Commission, 2010) - is, we believe, too simplistic. Moreover, such a simple model offers little guidance on how older workers may remain employable. Current research, however, neglects to look into potential mediators of the relationship between age and employability. In sum, despite the practical urgency and importance of the topic, we lack the necessary knowledge to give advice about how to manage employees to sustain their employability during the process of aging.

In this conceptual chapter, we present a model of how chronological age, learning activities, and their motivational antecedents may explain older employees' employability. Specifically, we consider future time perspective (Lang \& Carstensen, 2002), goal orientation (Elliot \& McGregor, 2001), and formal and informal learning activities (see Figure 1). Such a focus on individuals' attributes is warranted, as previous studies of employability have largely ignored individual differences and focused on contextual variables, such as the organizational culture or job demands (e.g., Evers, Kreijns, Van der Heijden, \& Gerrichhauzen, 2011; Thijssen, Van der Heijden, \& Rocco, 2008; Van der Heijden \& Bakker, 2011; Van der Heijden, Boon, et al., 2009; Van Emmerik, Schreurs, De Cuyper, Jawahar, \& Peeters, 2012; Wittekind, Raeder, \& Grote, 2010). The focus on psychological and behavioral factors provides alternative explanations of how employability is shaped during the aging process and extends current models (e.g., Van der Heijden, De Lange, Demerouti, \& Van der Heijde, 2009). 


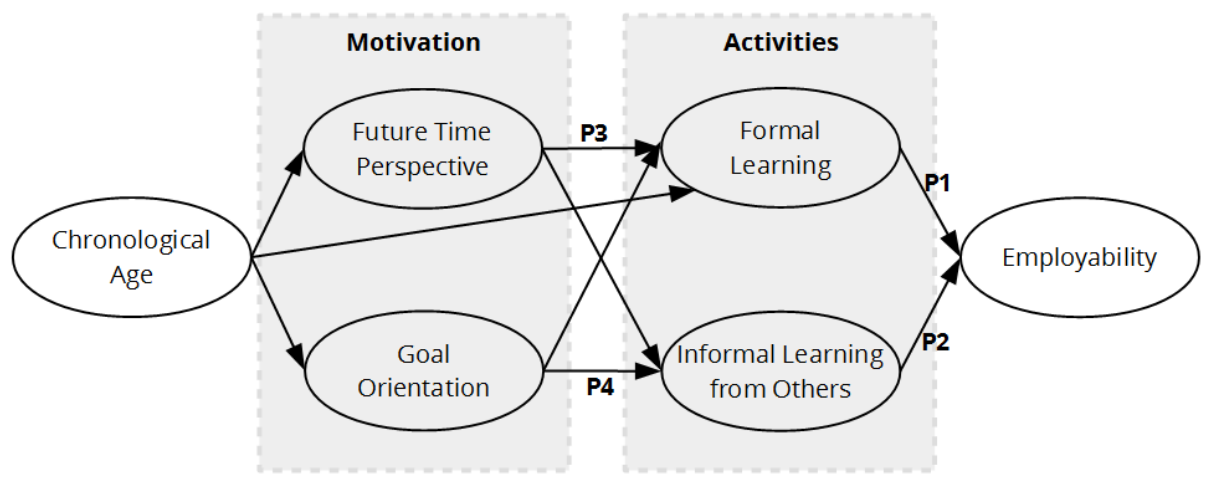

Figure 1: Conceptual model of this chapter depicting the propositions (P1 to P4).

\section{EMPLOYABILITY: A COMPETENCE-BASED PERSPECTIVE}

Gazier (2001) identifies three waves of employability research, in which the concept was adapted to the labor market situation. Early in the $20^{\text {th }}$ century an absolute definition of employability based on whether one was able and willing to work was introduced. In the 1950s, research gradually also considered the labor market demand. Since the 1990s, employability research has focused on three areas: labor market outcomes, individuals' responsibility to develop transferable skills due to increasingly inter-organizational careers, and employability's relativity in terms of supply and demand on the labor market.

The accelerating rate of innovation makes it increasingly inappropriate to frame employability in terms of specific labor market demands. Instead, we define being employable as having a set of competences that enables people to fulfill, acquire, or create work (Van der Heijde \& Van der Heijden, 2006). For that, a broad package of competences (Wright \& Snell, 1998) that includes social and adaptive competences (Rodriguez, Patel, Bright, Gregory, \& Gowing, 2002) on top of technical domain knowledge, needs to be taken into account. Van der Heijde and Van der Heijden (2006) include occupational expertise as an important prerequisite for employability, but note that also other factors weigh heavily. Proactive, self-initiated screening and preparation for potential changes in job and career requirements and conditions (anticipation and optimization) 
and reactive adaptation and resilience to them (personal flexibility) are needed in today's fast moving business world. Furthermore, identification with the organization's goals and the ability to work together with others are needed (corporate sense). Last, balance, the ability to appropriately weigh employer's interests against own interests, was identified as a key competence of employability.

Previous research has found that self-ratings of employability are more important than potential employers' ratings, since employees act based on their own perceptions (Fugate et al., 2004; Van den Broeck et al., 2013; Van Emmerik et al., 2012). Similarly, Kinnunen et al. (2011) derive the importance of self-perceived employability from Lazarus and Folkman's (1984) transactional stress theory: employees who perceive themselves as employable feel less threatened by the environment, experience less strain (Berntson \& Marklund, 2007), and perform better. Therefore, we focus on the employees' own perceptions of their employability in our model.

\section{Age}

Age is a very broad concept that may be viewed from different perspectives (Diehl et al., 2014; Schalk et al., 2010); for instance: functional age, which is based on the ability of a person to perform certain tasks on a daily basis (Sharkey, 1987), psychological age, which refers to how old a person feels subjectively (Stephan, Demulier, \& Terracciano, 2012), organizational age, which is based on the tenure in the same organization, life-span age, which considers biological and societal factors in an integrative way and focuses on the roles people take during their lives (R. Schulz \& Heckhausen, 1996), or chronological age, which measures the time passed since birth.

Both in research and practice, chronological age is used most prominently. This is also true in research about employability, where chronological age is often included in the analyses - at least as a covariate. Previous studies predominantly find negative relationships between age and employability (De Cuyper, Mauno, Kinnunen, \& Mäkikangas, 2011; Nauta, De Vroome, Cox, Korver, \& Kraan, 2005; Raemdonck, Tillema, Grip, Valcke, \& Segers, 2012; Rothwell \& Arnold, 2007; Van der Heijden, 2002; Van Vuuren, Caniels, \& Semeijn, 2011; Wittekind et al., 2010) and related concepts, such 
as workability (Nielsen, 1999) and career opportunities (Van Veldhoven \& Dorenbosch, 2008). We only found one study that does not show a significant relationship at all (Van der Heijden, Boon, et al., 2009).

Despite these consistent findings, it is difficult to derive implications from them. This is because chronological age is a proxy measure for many changes related to aging: physical and mental changes, ageism, effects of the period of time or the cohort (Hall, Mairesse, \& Turner, 2007). It is difficult to disentangle those different effects from each other. A second problem is that the older people get and the more experience they accumulate, the more heterogeneous they become (Carstensen, 2006; Staudinger \& Bowen, 2011). Consequently, the predictive value of chronological age diminishes. Additionally, it is questionable which recommendations should be given to decision makers in organizations and policy. After all, individuals' chronological age may not be altered. Despite these shortcomings, both practitioners and researchers often use chronological age as an easy to measure proxy for the physical, cognitive, social, and emotional changes associated with human development (Pitt-Catsouphes, Matz-Costa, \& Besen, 2009).

\section{ACTIVITIES OF FORMAL LEARNING AND INFORMAL LEARNING FROM OTHERS}

Both formal and informal learning may help to develop the necessary competences to stay employable. Formal learning means all the learning inside a structure deliberately created for that purpose (CEDEFOP, 2008), for instance in seminars and workshops. It received the majority of attention by human resource development (HRD) researchers and practitioners in the past, but is increasingly challenged for its often insufficient transfer to the workplace (Blume, Ford, Baldwin, \& Huang, 2010; Ford \& Weissbein, 1997). Nevertheless, it is an important measure for HRD, since it is arguably easier to plan and observe than informal learning.

Informal learning is less pre-structured, more in control of the learner, embedded in daily working activities, and may happen unconsciously (cf. Livingstone, 2001; Marsick \& Watkins, 2001). Eraut (2007) identifies encounters and relationships at work as well as opportunities for receiving feedback and support as important factors for learning at work. 
Additionally, he mentions participation in group activities, work alongside others, and consultations among the activities most conducive for learning. This indicates a high importance of the social component of workplace learning. Therefore, we focus on informal learning from others for the remainder of this chapter. Eraut (2007) and Van der Heijden, Boon, et al. (2009) suggest that informal learning is needed to optimize overall learning efficiency; Cross (2007) finds informal learning as being superior in terms of efficiency and effectiveness.

Any given learning situation is always a mixture of formal and informal learning, but to varying degrees (Eraut, 2004). Consequently, we take both types of learning into account simultaneously, but separately. This extends the study of De Vos et al. (2011), which found positive effects of participation in competency development initiatives on self-perceived employability. There, both formal and informal learning activities were included, but were not separated from each other in the analyses. In general, both formal and informal learning activities may enhance individuals' competences and thereby contribute to their employability (Forrier \& Sels, 2003).

\section{Formal learning, age, and employability}

With respect to the relation between age and formal learning, most studies indicate that older people are less interested in attending formal trainings (Kanfer \& Ackerman, 2004; Livingstone, 1999; Warr \& Birdi, 1998; Warr, 2001) and also are offered fewer opportunities to do so (Beck, 2012; Grima, 2011; Urwin, 2006; Van Vianen, Dalhoeven, \& De Pater, 2011). On the one hand, this negative relationship between age and formal learning activity may be explained by mental changes associated with the process of aging. For instance, research has found that cognitive processing slows down (Salthouse, 1996) and that the working memory declines (ReuterLorenz et al., 2000; Salthouse \& Babcock, 1991). This deterioration of abilities may discourage participation in formal trainings (Zwick, 2011). On the other hand, we need to consider negative stereotypes against older workers (Maurer, Wrenn, \& Weiss, 2003; Wrenn \& Maurer, 2004). Employees' chronological age does play a large role in how they are perceived by others. 
Eventually, this also shapes their own attitudes towards learning, and they become less motivated to participate in trainings (Lawrence, 1988).

Empirical research finds that formal learning contributes to one's employability. For instance, Groot and Van den Brink (2000) find positive effects of education and training on employability among Dutch employees. Sanders and De Grip (2004) study low-skilled workers and confirm a positive effect of formal training on intra-firm employability, but they do not find any effect of training on external employability. Van der Heijden et al. (2009) note positive relationships between formal learning and three subdimensions of employability: occupational expertise, anticipation and optimization, and corporate sense. Froehlich, Beausaert, Segers, and Gerken (2014) report that the number of hours spent in formal learning activities positively affects anticipation and optimization. These consistent findings suggest formal learning to positively affect employability.

Previous research found positive relationships between formal learning and employability and negative relationships between chronological age and formal learning. Therefore, we propose that formal learning enhances employability. At the same time, we propose that chronological age affects employability indirectly via formal learning.

Proposition 1: Formal learning positively affects employability and partially

mediates the negative relationship between chronological age and employability.

\section{Informal learning from others, age, and employability}

Findings of studies researching a link between chronological age and informal learning from others are inconclusive. Specifically, while Tikkanen (2002) and Gupta et al. (1999) find a decreased use of informal learning and feedback-seeking among older workers and Van der Heijden et al. (2009) note decreasing networking activity with increasing age, Livingstone (1999) finds "that [older people] spend nearly as much time on informal learning as middle-aged adults" (p. 13). Schulz and Stamov-Roßnagel (2010), too, find no significant difference between different ages in their sample of 470 employees of a German mail-order firm and argue that "[i]nformal learning might offer more opportunities to compensate for cognitive ageing effects so that negative age differences might disappear" (p. 395). Indeed, Berg and 
Chyung (2008) find a positive correlation between age and engagement in informal learning when surveying 125 professionals in the field of workplace learning and performance improvement. Kyndt, Dochy, and Nijs (2009) find that younger employees (20 - 29 years) receive the fewest opportunities for feedback and knowledge acquisition (e.g., from work groups, project teams, guest speakers). Conversely, middle aged employees (30 - 39 years) get the most opportunities for feedback and knowledge acquisition. Interestingly, when it comes to acquiring information, the oldest employees score higher and the middle aged employees score the lowest.

It appears that in pursuing informal learning from others in terms of information- and feedback-seeking, individuals are more in control of their own learning effort (Marsick \& Watkins, 2001) and less dependent on their employers' resources or others' stereotypes. Thereby, they are also more independent of the negative age effects mentioned above. Moreover, informal learning is often not even perceived as learning by the learners themselves (Eraut, 2004, p. 249) and thus negative self-perceptions of one's intellectual capabilities might be circumvented.

This is important, because informal learning from others may enhance employability. For instance, by receiving feedback, employees become aware of their development needs. Similarly, seeking for information reduces uncertainty. New employees may focus especially on information that helps them to fit in the new organization (Morrison, 1993, 2002). Later, they may seek information needed to perform better and to develop their career. Employability is a broad concept that includes both of these goals. Being integrated in the organization and being knowledgeable about the domain of work are two of the dimensions of employability.

The relationship between informal learning from others and employability has hardly been studied empirically. Most notably, Van der Heijden et al. (2009) have researched this relationship among non-academic university employees. They found networking within and outside the own organization (Bozionelos, 2003) to positively affect all five dimensions of employability. Moreover, interaction with one's supervisor had positive effects on balance and corporate sense. Van der Rijt et al. (2012) find feedback-seeking to affect perceived career development positively among employees in the financial sector in an early career stage. Froehlich et al. 
(2014) report several forms of informal learning from others, such as feedback-seeking and help-seeking, to positively affect occupational expertise, anticipation and optimization, and personal flexibility. Aligned with our general assumption that actual learning behavior is needed to develop the competences to maintain employability, we propose a positive effect of informal learning from others on employability.

Proposition 2: Informal learning from others positively affects employability.

\section{MOTIVATIONAL ANTECEDENTS OF LEARNING ACTIVITIES: SOCIOEMOTIONAL SELECTIVITY AND GOAL ORIENTATION}

We strive to understand the development of competences needed for employability through three lenses: age, motivation, and learning activity. Two theories appear especially suitable and offer insights concerning the antecedents of learning activities: socioemotional selectivity theory - and the associated concept of future time perspective - and goal orientation theory.

\section{Socioemotional selectivity theory and future time perspective}

Socioemotional selectivity theory posits that individuals select and pursue their goals in alignment with their (working) life's time horizon (Carstensen, Isaacowitz, \& Charles, 1999). Specifically, when people have a limited future time perspective they seek emotional well-being and shortterm benefits. Conversely, when they view time as open-ended, goals to acquire knowledge, experience novelty, etc. become more important (Carstensen, 2006; Seijts, 1998). This unidimensionality of the construct was later questioned by Cate and John (2007), who found that a two factor solution fits the data better. Accordingly, they suggest investigating two separate constructs: focus on opportunities and focus on limitations.

Socioemotional selectivity theory predicts that older people perceive their remaining time and opportunities as more limited, as they are closer to life-expectancy. Empirical studies report that older people see more limitations and less opportunities for their future life (Cate \& John, 2007; De Lange, Bal, Van der Heijden, De Jong, \& Schaufeli, 2011; Lang \& Carstensen, 2002; Zacher \& Frese, 2011). We maintain that similar effects will be 
observable the closer employees get to retirement age and the end of their working life.

Socioemotional selectivity theory suggests that people who perceive many opportunities for themselves in the future are more motivated to learn. While there is little empirical evidence for work-related formal and informal learning, we know from educational psychology literature that an extensive future time perspective is associated with, for instance, an increased likelihood of actually completing tasks (Bembenutty \& Karabenick, 2004), increased persistence to study (Horstmanshof \& Zimitat, 2007), and better academic performance (De Volder \& Lens, 1982). In a similar vein, Janeiro and Marques (2010) find future time orientation to be positively related to career attitudes among Portuguese pupils (Creager, 2011). In a more general sense, Lang and Carstensen (2002) report effects of future time perspective on the composition of one's social network. Specifically, while individuals perceiving the future as limited prefer emotional goals and thus relatives and formal partners, individuals who have an expansive perception of the future prefer to interact with acquaintances and knowledgeable or controversial partners to fulfill their desire for growth. This is attributable to the different goals associated with different perceptions of future time and might indicate an influence of future time perspective on the undertaking of learning activities. In combination with the strong correlations found between chronological age and future time perspective, this suggests that chronological age affects the undertaking of learning activities indirectly via future time perspective. The relationship between focus on opportunities and limitations and learning activity has not been researched in detail yet. We therefore assume similar effects for formal learning activities and informal learning from others.

Proposition 3: A focus on opportunities positively affects the undertaking of activities of formal learning and informal learning from others and partially mediates the negative relationships between chronological age and activities of formal learning and informal learning from others. The opposite is true for a focus on limitations. 


\section{Life span development theory and the changes in goal orientation}

Goal orientation research investigates how people interpret and handle achievement situations (Brett \& VandeWalle, 1999). There, two factors are important: the definition and valence of competence. One's competence is either defined against an absolute standard, own past performance, or others' performance. The former two share many similarities and both contribute to a mastery orientation, while the latter contributes to a performance orientation. Individuals with a dominant mastery goal orientation view ability as an attribute that can be expanded with effort. Conversely, performance oriented people see ability as a fixed attribute, effort as a lack of ability, and feedback as judgmental (Elliott \& Dweck, 1988). The valence ascribed to competence determines whether success is approached or failure avoided. For instance, an employee may attempt to perform better than her colleagues (approach orientation) or attempt to circumvent mistakes (avoid orientation). Depending on the definition and valence of competence, four goal orientations can be distinguished (Janssen \& Prins, 2007). People may aim to develop competences and skills (mastery approach orientation), avoid deterioration and loss of competences and skills (mastery avoid orientation), demonstrate competences to get favorable judgments (performance approach orientation), or avoid demonstration of lack of competences to eschew negative judgments (performance avoid orientation).

Goal orientation has been conceptualized as a rather stable concept (Steele-Johnson, Beauregard, Hoover, \& Schmidt, 2000). However, life span developmental theory maintains that people experience more losses and less gains as they age (Baltes, 1987). For instance, this includes the deterioration of cognitive and physical functioning (Bassey, 1998; Schaie, 1984). As a consequence, individuals adjust their goals. If enhancement is not possible (approach orientation), they may try to at least maintain the status quo (avoid orientation) (Baltes \& Baltes, 1990). This makes maintenance goals - and an avoid orientation - more likely.

Empirical research confirms that older people increasingly focus on maintenance goals (Ebner, Freund, \& Baltes, 2006; Ogilvie, Rose, \& Heppen, 2010; Zwick, 2011). Put differently, the valence ascribed to competence may 
change from an approach orientation to an avoid orientation during the process of aging (De Lange, Van Yperen, Van der Heijden, \& Bal, 2010).

Previous research pointed out the importance of goal orientation for employees' learning and development. Several studies find mastery approach orientation to be beneficial to one's engagement in formal and informal learning (Fisher \& Ford, 1998; Janssen \& Prins, 2007; Payne, Youngcourt, \& Beaubien, 2007). For mastery and performance avoid orientations, findings show mostly negative effects on learning (Karabenick, 2004; Payne et al., 2007; Van Yperen, Elliot, \& Anseel, 2009; VandeWalle \& Cummings, 1997). Both positive and negative effects have been found for a performance approach orientation. Studies conducted among students find negative effects of a performance approach orientation on information-, feedback-, and help-seeking (Janssen \& Prins, 2007; Karabenick, 2004; VandeWalle \& Cummings, 1997). Conversely, Van der Rijt et al. (2012) report positive effects of a performance approach orientation on feedback-seeking among financial experts, which we consider a more adequate sample also for our model. In sum, previous evidence suggests links of goal orientation with both chronological age and formal and informal learning from others. We propose that chronological age affects the undertaking of activities of formal learning and informal learning from others indirectly via both approach and avoid goal orientations (cf. Propositions 1 and 2).

Proposition 4: Approach goal orientations increase the undertaking of activities of formal learning and informal learning from others. The opposite is the case for avoid goal orientations. Both partially mediate the positive relationships between chronological age and activities of formal learning and informal learning from others.

\section{DISCUSSION AND IMPLICATIONS}

In this conceptual chapter we proposed a model of how chronological age, motivational antecedents, and learning activities may influence employability. We developed the model based on theories and empirical evidence in the fields of human resource development, psychology, and educational sciences. Given the demographic shift in most societies of the world and the fast rate of change and innovation, a model of employability that considers employees' age is highly warranted. Former 
models on employability and workplace learning mostly ignored the factor of age, or at least did not provide hypotheses on how chronological age may have effects. We offer explanations of how chronological age, despite its poor characteristics as a predictor, might still affect employability indirectly. Specifically, we proposed that motivation - in terms of future time perspective and goal orientation - and activities of formal learning and informal learning from others need to be considered. Since an individual's chronological age cannot be changed, it is important to recognize these mediating variables, which may be targeted more easily by HRD or age management initiatives. Thus, the model may not only guide future research in this field, but also provide a framework to advise human resource managers about how to sustain older employees' employability.

Similar to our model, Van der Heijde et al. (2009) conceptualized how employee characteristics, such as chronological age, and organizational factors affect formal and informal job-related learning and, in turn, employability. However, this model does not attempt to explain how chronological age actually affects the undertaking of activities of formal learning and informal learning from others. Relying on socioemotional selectivity and goal orientation theory, we offer an explanation for this relationship. This line of reasoning may also inform future empirical studies concerned with chronological age. Researchers need to be aware of the complexity of age and be cautious when measuring it. It might be a fruitful approach to consider future time perspective as an alternative measure next to chronological age.

The conceptual model presented in this chapter may serve as a framework for further research at the intersection of employability, learning, and age management. It brings to attention the importance of studying these concepts in an integrated way, rather than in isolation, as was mostly done in previous research. While the propositions were mainly formulated based on previous empirical evidence, especially the proposed mediating effects have not been empirically tested before and warrant closer empirical examination and validation.

We developed a model of employability based on three perspectives: age, motivation, and learning activity. This constrained view is necessary to limit the complexity of the model and to focus on what research shows may 
be the most important influences. At the same time, this may preclude the discussion of other concepts, and may be regarded as a limitation of the current model. First, our conceptualization of informal learning was quite narrow and focused on learning from others only. Future research may extend the model to include also other forms of learning, for example the learning value of the job itself (Van der Heijden \& Bakker, 2011; Van der Heijden, Boon, et al., 2009). At the same time, further research is needed to formulate more specific hypotheses for each dimension of employability. We do not sufficiently understand which kind of learning activity or learning content enhances which dimension of employability. Second, as we conceptualized our model on the level of an individual employee, we focused on personal attributes that influence older employees' employability. Nevertheless, contextual variables on the task, job, and organizational level may influence the relationships proposed in the model. Future research therefore needs to test the model in different settings and consider contextual factors such as task complexity and variety (Hackman \& Oldham, 1975), rate of change (McCauley, Ruderman, Ohlott, \& Morrow, 1994), stereotypes in the workplace (John, 2013; Kim \& Mo, 2014), and learning culture (Marsick \& Watkins, 2003; Marsick, 2013). Third, we assumed employability as the raison d'être of work-related learning. However, especially with an increasing chronological age, people may have different goals in mind when learning, as proposed by socioemotional selectivity theory (e.g., one employee may pursue emotional or social goals and therefore strives to connect to other employees, while another employee is more concerned with her financial situation and therefore puts an emphasis on developing the necessary competences to remain employable). Fourth, the domain of this model is clearly set in a workplace setting. However, the actions set outside of one's work may influence employability as well (Gorard, Fevre, \& Rees, 1999). The system of Recognition of Acquired Competences, which is established in many countries, supports this thought. This system acknowledges that competences might stem from experiences outside the training or classroom or even the workplace. For instance, they may have been acquired during volunteer work, in the sports club, or through a private course (Joosten-Ten Brinke, Sluijsmans, Brand-Gruwel, \& Jochems, 2008). 
The proposed model may inform HRD practice when designing interventions to enhance work-related learning of the older workforce, as it explicates the learning process and major antecedents of it. For example, the proposed effects of future time perspective and goal orientation may suggest to clarify the instrumentality of learning activities for future success (Simons, Vansteenkiste, Lens, \& Lacante, 2004), to facilitate long-term planning (Gellert, Ziegelmann, Lippke, \& Schwarzer, 2012), or to implement personal development plans that span over several years (Beausaert, Segers, Van der Rijt, \& Gijselaers, 2011). Managers are advised to take into account the agenda of age management and human resource development in a more integrated fashion. Furthermore, the use of chronological age as a basis for management decision needs to be carefully assessed and revised. Instead, individual differences both in motivation and behavior need to be considered. While the generation of these data is certainly more expensive than relying on chronological age as a measure, this allows more considerate decision making. 


\section{REFERENCES}

Baltes, P. B. (1987). Theoretical propositions of life-span developmental psychology: On the dynamics between growth and decline. Developmental Psychology, 23(5), 611-626. doi:10.1037//00121649.23.5.611

Baltes, P. B., \& Baltes, M. M. (1990). Psychological perspectives on successful aging: The model of selective optimization with compensation. In P. B. Baltes \& M. M. Baltes (Eds.), Successful aging: Perspectives from the behavioral sciences (pp. 1-34). New York City, NY: Cambridge University Press.

Bassey, E. J. (1998). Longitudinal changes in selected physical capabilities: muscle strength, flexibility and body size. Age and Ageing, 27(S3), 12-6.

Beausaert, S. A. J., Segers, M. S. R., Van der Rijt, J., \& Gijselaers, W. H. (2011). The Use of Personal Development Plans (PDPs) in the Workplace: A Literature Review. In P. Van den Bossche, W. H. Gijselaers, \& R. G. Milter (Eds.), Building Learning Experiences in a Changing World (Vol. 3, pp. 235265). Dordrecht: Springer Netherlands. doi:10.1007/978-94-007-0802-0

Beck, V. (2012). Employers' views of learning and training for an ageing workforce. Management Learning, 45(2), 200-215. doi:10.1177/1350507612468421

Bembenutty, H., \& Karabenick, S. A. (2004). Inherent Association Between Academic Delay of Gratification, Future Time Perspective, and SelfRegulated Learning. Educational Psychology Review, 16(1), 35-57. doi:10.1023/B:EDPR.0000012344.34008.5c

Berg, S. A., \& Chyung, S. Y. (2008). Factors that influence informal learning in the workplace. Journal of Workplace Learning, 20(4), 229-244. doi:10.1108/13665620810871097

Berntson, E., \& Marklund, S. (2007). The Relationship Between Employability and Subsequent Health. Work \& Stress, 21(3), 279-292. doi:10.1080/02678370701659215

Billett, S. (2011). Promoting Lifelong Employability for Workforce Aged Over 45: Singaporean Workers' Perspectives. International Journal of Continuing Education and Lifelong Learning, 3(2), 57-73. 
Blume, B. D., Ford, J. K., Baldwin, T. T., \& Huang, J. L. (2010). Transfer of Training: A Meta-Analytic Review. Journal of Management, 36(4), 10651105. doi:10.1177/0149206309352880

Bozionelos, N. (2003). Intra-Organizational Network Resources: Relation to Career Success and Personality. International Journal of Organizational Analysis, 11(1), 41-66.

Brett, J. F., \& VandeWalle, D. (1999). Goal Orientation and Goal Content as Predictors of Performance in a Training Program. Journal of Applied Psychology, 84(6), 863-873. doi:10.1037/0021-9010.84.6.863

Carstensen, L. L. (2006). The Influence of a Sense of Time on Human Development. Science, 312(5782), 1913-1915. doi:10.1126/science. 1127488

Carstensen, L. L., Isaacowitz, D. M., \& Charles, S. T. (1999). Taking Time Seriously: A Theory of Socioemotional Selectivity. American Psychologist, 54(3), 165-181. doi:10.1037/0003-066X.54.3.165

Cate, R. A., \& John, O. P. (2007). Testing Models of the Structure and Development of Future Time Perspective: Maintaining a Focus on Opportunities in Middle Age. Psychology and Aging, 22(1), 186-201. doi:10.1037/0882-7974.22.1.186

CEDEFOP. (2008). Terminology of European education and training policy. Luxembourg: Office for Official Publications of the European Communities.

Clarke, M. (2008). Understanding and managing employability in changing career contexts. Journal of European Industrial Training, 32(4), 258-284. doi:10.1108/03090590810871379

Colley, L. (2013). Understanding Ageing Public Sector Workforces: Demographic challenge or a consequence of public employment policy design? Public Management Review, 16(7), 1030-1052. doi:10.1080/14719037.2013.771697

Creager, M. F. S. (2011). Practice and Research in Career Counseling and Development - 2010. Career Development Quarterly, 59(4), 482-528. doi:10.1002/j.2161-0045.2011.tb00973.x

Cross, J. (2007). Informal Learning. San Francisco, CA: Pfeiffer. 
De Cuyper, N., Mauno, S., Kinnunen, U., \& Mäkikangas, A. (2011). The role of job resources in the relation between perceived employability and turnover intention: A prospective two-sample study. Journal of Vocational Behavior, 78(2), 253-263. doi:10.1016/j.jvb.2010.09.008

De Lange, A. H., Bal, P. M., Van der Heijden, B. I. J. M., De Jong, N., \& Schaufeli, W. B. (2011). When I'm 64: Psychological Contract Breach, Work Motivation and the Moderating Roles of Future Time Perspective and Regulatory Focus. Work \& Stress, 25(4), 338-354. doi:10.1080/02678373.2011.632610

De Lange, A. H., Van Yperen, N. W., Van der Heijden, B. I. J. M., \& Bal, P. M. (2010). Dominant Achievement Goals of Older Workers and their Relationship with Motivation-Related Outcomes. Journal of Vocational Behavior, 77(1), 118-125. doi:10.1016/j.jvb.2010.02.013

De Volder, M. L., \& Lens, W. (1982). Academic Achievement and Future Time Perspective as a Cognitive-Motivational Concept. Journal of Personality and Social Psychology, 42(3), 566-571. doi:10.1037//0022-3514.42.3.566

De Vos, A., De Hauw, S., \& Van der Heijden, B. I. J. M. (2011). Competency development and career success: The mediating role of employability. Journal of Vocational Behavior, 79(2), 438-447. doi:10.1016/j.jvb.2011.05.010

Department for Business Innovation and Skills. (2011). Phasing Out the Default Retirement Age: Government Response to Consultation - Impact Assessment. London: Department for Business Innovation and Skills.

Diehl, M., Wahl, H.-W., Barrett, A. E., Brothers, A. F., Miche, M., Montepare, J. M., ... Wurm, S. (2014). Awareness of aging: Theoretical considerations on an emerging concept. Developmental Review. doi:10.1016/j.dr.2014.01.001

Ebner, N. C., Freund, A. M., \& Baltes, P. B. (2006). Developmental changes in personal goal orientation from young to late adulthood: from striving for gains to maintenance and prevention of losses. Psychology and Aging, 21(4), 664-78. doi:10.1037/0882-7974.21.4.664

Elliot, A. J., \& McGregor, H. A. (2001). A 2x2 Achievement Goal Framework. Journal of Personality and Social Psychology, 80(3), 501-519. 
Elliott, E. S., \& Dweck, C. S. (1988). Goals: an approach to motivation and achievement. Journal of Personality and Social Psychology, 54(1), 5-12.

Eraut, M. (2004). Informal Learning in the Workplace. Studies in Continuing Education, 26(2), 247-273. doi:10.1080/158037042000225245

Eraut, M. (2007). Learning from other People in the Workplace. Oxford Review of Education, 33(4), 403-422. doi:10.1080/03054980701425706

European Commission. (2010). Employment in Europe 2010. Luxembourg: Publications Office of the European Union. doi:10.2767/72770

Evers, A. T., Kreijns, K., Van der Heijden, B. I. J. M., \& Gerrichhauzen, J. T. G. (2011). An Organizational and Task Perspective Model Aimed at Enhancing Teachers' Professional Development and Occupational Expertise. Human Resource Development Review, 10(2), 151-179. doi:10.1177/1534484310397852

Fisher, S. L., \& Ford, J. K. (1998). Differential Effects of Learner Effort and Goal Orientation on Two Learning Outcomes. Personnel Psychology, 51(2), 397-420. doi:10.1111/j.1744-6570.1998.tb00731.x

Ford, J. K., \& Weissbein, D. A. (1997). Transfer of Training: An Updated Review and Analysis. Performance Improvement Quarterly, 10(2), 22-41.

Forrier, A., \& Sels, L. (2003). The concept employability: a complex mosaic. International Journal of Human Resources Development and Management, 3(2), 102-124.

Froehlich, D. E., Beausaert, S. A. J., Segers, M. S. R., \& Gerken, M. (2014). Learning to Stay Employable. Career Development International, 19(5), 508-525.

Fugate, M., Kinicki, A. J., \& Ashforth, B. E. (2004). Employability: A psychosocial construct, its dimensions, and applications. Journal of Vocational Behavior, 65(1), 14-38. doi:10.1016/j.jvb.2003.10.005

Gazier, B. (2001). Employability: the complexity of a policy notion. In P. Weinert, M. Baukens, P. Bóllerot, M. Pineschi-Gapénne, \& U. Walwei (Eds.), Employability: From Theory to Practice (pp. 3-23). New Brunswick, NJ: Transaction Books.

Gellert, P., Ziegelmann, J. P., Lippke, S., \& Schwarzer, R. (2012). Future time perspective and health behaviors: temporal framing of self-regulatory 
processes in physical exercise and dietary behaviors. Annals of Behavioral Medicine, 43(2), 208-18. doi:10.1007/s12160-011-9312-y

Gorard, S., Fevre, R., \& Rees, G. (1999). The apparent Decline of Informal Learning. Oxford Review of Education, 25(4), 437-454. doi:10.1080/030549899103919

Grima, F. (2011). The influence of age management policies on older employee work relationships with their company. International Journal of Human Resource Management, 22(6), 1312-1332. doi:10.1080/09585192.2011.559101

Groot, W., \& Van den Brink, H. M. (2000). Education, training and employability. Applied Economics, 32(5), 573-581. doi:10.1080/000368400322471

Gupta, A. K., Govindarajan, V., \& Malhotra, A. (1999). Feedback-Seeking Behavior within Multinational Corporations. Strategic Management Journal, 20(3), 205-222.

Hackman, J. R., \& Oldham, G. R. (1975). Development of the Job Diagnostic Survey. Journal of Applied Psychology, 60(2), 159-170.

Hall, B. H., Mairesse, J., \& Turner, L. (2007). Identifying age, cohort, and period effects in scientific research productivity: discussion and illustration using simulated and actual data on french physicists. Economics of Innovation and New Technology, 16(2), 37-41.

Horstmanshof, L., \& Zimitat, C. (2007). Future time orientation predicts academic engagement among first-year university students. British Journal of Educational Psychology, 77(3), 703-718. doi:10.1348/000709906X160778

Ilmarinen, J. E. (2001). Aging workers. Occupational and Environmental Medicine, 58(8), 546-52.

Janeiro, I. N., \& Marques, J. F. (2010). Career coping styles: differences in career attitudes among secondary school students. International Journal for Educational and Vocational Guidance, 10(1), 35-48. doi:10.1007/s10775-009-9170-3

Janssen, O., \& Prins, J. (2007). Goal orientations and the seeking of different types of feedback information. Journal of Occupational and 
Organizational Psychology, 235-249. doi:10.1348/096317906X103410

John, B. (2013). Patterns of Ageism in Different Age Groups. Journal of European Psychology Students, 4, 16-36.

Joosten-Ten Brinke, D., Sluijsmans, D. M. A., Brand-Gruwel, S., \& Jochems, W. M. G. (2008). The quality of procedures to assess and credit prior learning: Implications for design. Educational Research Review, 3(1), 5165. doi:10.1016/j.edurev.2007.08.001

Kanfer, R., \& Ackerman, P. L. (2004). Aging, Adult Development, and Work Motivation. Academy of Management Review, 29(3), 440-458. doi:10.2307/20159053

Karabenick, S. A. (2004). Perceived Achievement Goal Structure and College Student Help Seeking. Journal of Educational Psychology, 96(3), 569-581. doi:10.1037/0022-0663.96.3.569

Kim, D. S., \& Mo, S. H. (2014). Stereotypical Beliefs on Old Korean Workers. Ageing International. doi:10.1007/s12126-014-9200-4

Kinnunen, U., Mäkikangas, A., Mauno, S., Siponen, K., \& Nätti, J. (2011). Perceived employability: Investigating outcomes among involuntary and voluntary temporary employees compared to permanent employees. Career Development International, 16(2), 140-160. doi:10.1108/13620431111115604

Kyndt, E., Dochy, F., \& Nijs, H. (2009). Learning Conditions for Non-Formal and Informal Workplace Learning. Journal of Workplace Learning, 21(5), 369-383. doi:10.1108/13665620910966785

Lang, F. R., \& Carstensen, L. L. (2002). Time counts: Future time perspective, goals, and social relationships. Psychology and Aging, 17(1), 125-139. doi:10.1037//0882-7974.17.1.125

Lawrence, B. S. (1988). New Wrinkles in the Theory of Age: Demography, Norms, and Performance Ratings. Academy of Management Journal, 31(2), 309-337.

Lazarus, R., \& Folkman, S. (1984). Stress, Appraisal, and Coping. New York: Springer. 
Livingstone, D. W. (1999). Exploring the Icebergs of adult learning: Findings of the first Canadian Survey of Informal Learning Practices. Canadian Journal for the Study of Adult Education, 13(10), 49-72.

Livingstone, D. W. (2001). Adults' Informal Learning: Definitions, Findings, Gaps and Future Research (No. 21). Toronto, Ontario: Centre for the Study of Education and Work.

Malinen, S., \& Johnston, L. (2013). Workplace ageism: discovering hidden bias. Experimental Aging Research, 39(4), 445-65. doi:10.1080/0361073X.2013.808111

Marsick, V. J. (2013). The Dimensions of a Learning Organization Questionnaire (DLOQ): Introduction to the Special Issue Examining DLOQ Use Over a Decade. Advances in Developing Human Resources, 15(2), 127-132. doi:10.1177/1523422313475984

Marsick, V. J., \& Watkins, K. E. (2001). Informal and Incidental Learning. New Directions for Adult and Continuing Education, 2001(89), 25-34. doi:10.1002/ace.5

Marsick, V. J., \& Watkins, K. E. (2003). Demonstrating the Value of an Organization's Learning Culture: The Dimensions of the Learning Organization Questionnaire. Advances in Developing Human Resources, 5(2), 132-151. doi:10.1177/1523422303251341

Maurer, T. J., \& Chapman, E. F. (2013). Ten years of career success in relation to individual and situational variables from the employee development literature. Journal of Vocational Behavior, 83(3), 450-465. doi:10.1016/j.jvb.2013.07.002

Maurer, T. J., Wrenn, K. A., \& Weiss, E. M. (2003). Toward Understanding and Managing Stereotypical Beliefs about Older Workers' Ability and Desire for Learning and Development. In J. Martocchio (Ed.), Research in Personnel and Human Resources Management (Vol. 22, pp. 253-285). Bingley: Emerald Group Publishing. doi:10.1016/S0742-7301(03)220065

McCauley, C. D., Ruderman, M. N., Ohlott, P. J., \& Morrow, J. E. (1994). Assessing the developmental components of managerial jobs. Journal of Applied Psychology, 79(4), 544-560. doi:10.1037/0021-9010.79.4.544 
Midtsundstad, T. I. (2011). Inclusive workplaces and older employees: an analysis of companies' investment in retaining senior workers. International Journal of Human Resource Management, 22(6), 1277-1293. doi:10.1080/09585192.2011.559099

Midtsundstad, T. I., \& Bogen, H. (2014). Active Aging Policies between Individual Needs and Collective Goods. A Study of Active Aging Policies and Practices in Norway. Nordic Journal of Working Life Studies, 4(2), 139-158.

Morrison, E. W. (1993). Newcomer Information Seeking: Exploring Types, Modes, Sources, and Outcomes. Academy of Management Review, 36(3), 557-589.

Morrison, E. W. (2002). Information Seeking Within Organizations. Human Communication Research, 28(2), 229-242.

Nauta, A., De Vroome, E., Cox, E., Korver, T., \& Kraan, K. (2005). De invloed van functietype op het verband tussen leeftijd en inzetbaarheid [The influence of function type on the relationship between age and employability]. Gedrag \& Organisatie, 18(6), 326-337.

Nielsen, J. (1999). Employability and Workability among Danish Employees. Experimental Aging Research, 25(4), 393-397.

OECD. (2012). OECD Environmental Outlook to 2050. Paris: OECD Publishing. doi:10.1787/9789264122246-en

Ogilvie, D. M., Rose, K. M., \& Heppen, J. B. (2010). A Comparison of Personal Project Motives in Three Age Groups. Basic and Applied Social Psychology, 23(3), 207-215.

Payne, S. C., Youngcourt, S. S., \& Beaubien, J. M. (2007). A meta-analytic examination of the goal orientation nomological net. The Journal of Applied Psychology, 92(1), 128-50. doi:10.1037/0021-9010.92.1.128

Pitt-Catsouphes, M., Matz-Costa, C., \& Besen, E. (2009). Workplace Flexibility: Findings from the Age \& Generations Study. Issue Brief No. 19. Chestnut Hill: Sloan Center on Aging \& Work at Boston College.

Raemdonck, I., Tillema, H. H., Grip, A., Valcke, M., \& Segers, M. S. R. (2012). Does Self-directedness in Learning and Careers Predict the 
Employability of Low-Qualified Employees? Vocations and Learning, 5(2), 137-151. doi:10.1007/s12186-011-9072-7

Razin, A., \& Sadka, E. (2005). The Decline of the Welfare State. Cambridge, MA: MIT Press.

Reuter-Lorenz, P. a, Jonides, J., Smith, E. E., Hartley, A., Miller, A., Marshuetz, C., \& Koeppe, R. a. (2000). Age differences in the frontal lateralization of verbal and spatial working memory revealed by PET. Journal of Cognitive Neuroscience, 12(1), 174-87.

Rodriguez, D., Patel, R., Bright, A., Gregory, D., \& Gowing, M. K. (2002). Developing competency models to promote integrated human resource practices. Human Resource Management, 41(3), 309-324. doi:10.1002/hrm.10043

Rothwell, A., \& Arnold, J. (2007). Self-perceived employability: Development and validation of a scale. Personnel Review, 36(1), 23-41. doi:10.1108/00483480710716704

Salthouse, T. A. (1996). The processing-speed theory of adult age differences in cognition. Psychological Review, 103(3), 403-428.

Salthouse, T. A., \& Babcock, R. L. (1991). Decomposing adult age differences in working memory. Developmental Psychology, 27(5), 763-776. doi:10.1037//0012-1649.27.5.763

Sanders, J., \& De Grip, A. (2004). Training, Task Flexibility and Low-Skilled Workers' Employability. International Journal of Manpower, 25(1), 73-89. doi:10.1108/01437720410525009

Schaie, K. W. (1984). Midlife Influences Upon Intellectual Functioning in Old Age. International Journal of Behavioral Development, 7(4), 463-478. doi:10.1177/016502548400700405

Schalk, R., Van Veldhoven, M. J. P. M., De Lange, A. H., De Witte, H., Kraus, K., Stamov-Roßnagel, C., ... Zacher, H. (2010). Moving European Research on Work and Ageing Forward: Overview and Agenda. European Journal of Work and Organizational Psychology, 19(1), 76-101. doi:10.1080/13594320802674629 
Schulz, M., \& Stamov-Roßnagel, C. (2010). Informal workplace learning: An exploration of age differences in learning competence. Learning and Instruction, 20(5), 383-399. doi:10.1016/j.learninstruc.2009.03.003

Schulz, R., \& Heckhausen, J. (1996). A life span model of successful aging. The American Psychologist, 51(7), 702-714.

Segal, D. L., Qualls, S. H., \& Smyer, M. A. (2011). Aging and Mental Health (2nd ed.). Chichester: Wiley-Blackwell.

Seijts, G. H. (1998). The Importance of Future Time Perspective in Theories of Work Motivation. Journal of Psychology, 132(2), 154-168.

Sharkey, B. J. (1987). Functional vs chronologic age. Medicine and Science in Sports and Exercise, 19(2), 174-178.

Simons, J., Vansteenkiste, M., Lens, W., \& Lacante, M. (2004). Placing Motivation and Future Time Perspective Theory in a Temporal Perspective. Educational Psychology Review, 16(2), 121-139. doi:10.1023/B:EDPR.0000026609.94841.2f

Staudinger, U. M., \& Bowen, C. E. (2011). A systemic approach to aging in the work context. Zeitschrift für ArbeitsmarktForschung, 44(4), 295-306. doi:10.1007/s12651-011-0086-2

Steele-Johnson, D., Beauregard, R. S., Hoover, P. B., \& Schmidt, A. M. (2000). Goal orientation and task demand effects on motivation, affect, and performance. Journal of Applied Psychology, 85(5), 724-738. doi:10.1037//0021-9010.85.5.724

Stephan, Y., Demulier, V., \& Terracciano, A. (2012). Personality, self-rated health, and subjective age in a life-span sample: The moderating role of chronological age. Psychology and Aging, 27(4), 875-880. doi:10.1037/a0028301

Thijssen, J. G. L., Van der Heijden, B. I. J. M., \& Rocco, T. S. (2008). Toward the Employability-Link Model: Current Employment Transition to Future Employment Perspectives. Human Resource Development Review, 7(2), 165-183. doi:10.1177/1534484308314955

Tikkanen, T. (2002). Learning at work in technology intensive environments. Journal of Workplace Learning, 14(3), 89-97. doi:10.1108/13665620210421902 
Urwin, P. (2006). Age discrimination: legislation and human capital accumulation. Employee Relations, 28(1), 87-97. doi:10.1108/01425450610633082

Van den Broeck, A., De Cuyper, N., Baillien, E., Vanbelle, E., Vanhercke, D., \& De Witte, H. (2013). Perception of organization's value support and perceived employability: insights from self-determination theory. International Journal of Human Resource Management, 1-15. doi:10.1080/09585192.2013.860385

Van der Heijde, C. M., \& Van der Heijden, B. I. J. M. (2006). A competencebased and multidimensional operationalization and measurement of employability. Human Resource Management, 45(3), 449-476. doi:10.1002/hrm.20119

Van der Heijden, B. I. J. M. (2002). Prerequisites to guarantee life-long employability. Personnel Review, 31(1), 44-61. doi:10.1108/00483480210412418

Van der Heijden, B. I. J. M., \& Bakker, A. B. (2011). Toward a Mediation Model of Employability Enhancement: A Study of Employee-Supervisor Pairs in the Building Sector. Career Development Quarterly, 59(3), 232-249. doi:10.1002/j.2161-0045.2011.tb00066.x

Van der Heijden, B. I. J. M., Boon, J., Van der Klink, M. R., \& Meijs, E. (2009). Employability Enhancement through Formal and Informal Learning: An Empirical Study among Dutch Non-Academic University Staff Members. International Journal of Training and Development, 13(1), 19-37. doi:10.1111/j.1468-2419.2008.00313.x

Van der Heijden, B. I. J. M., De Lange, A. H., Demerouti, E., \& Van der Heijde, C. M. (2009). Age Effects on the Employability-Career Success Relationship. Journal of Vocational Behavior, 74(2), 156-164. doi:10.1016/j.jvb.2008.12.009

Van der Rijt, J., Van den Bossche, P., Van de Wiel, M. W. J., Segers, M. S. R., \& Gijselaers, W. H. (2012). The role of individual and organizational characteristics in feedback-seeking behaviour in the initial career stage. Human Resource Development International, 15(3), 283-301. doi:10.1080/13678868.2012.689216 
Van Emmerik, I. J. H., Schreurs, B., De Cuyper, N., Jawahar, I. M., \& Peeters, M. C. W. (2012). The route to employability: Examining resources and the mediating role of motivation. Career Development International, 17(2), 104-119. doi:10.1108/13620431211225304

Van Veldhoven, M. J. P. M., \& Dorenbosch, L. (2008). Age, Proactivity and Career Development. Career Development International, 13(2), 112-131. doi:10.1108/13620430810860530

Van Vianen, A. E. M., Dalhoeven, B. A. G. W., \& De Pater, I. E. (2011). Aging and training and development willingness: Employee and supervisor mindsets. Journal of Organizational Behavior, 32(2), 226-247. doi:10.1002/job.685

Van Vuuren, T., Caniels, M. C. J., \& Semeijn, J. H. (2011). Duurzame inzetbaarheid en een leven lang leren [Sustainable employability and lifelong learning]. Gedrag \& Organisatie, 24(4), 356-373.

Van Yperen, N. W., Elliot, A. J., \& Anseel, F. (2009). The influence of masteryavoidance goals on performance improvement. European Journal of Social Psychology, 39(6), 932-943. doi:10.1002/ejsp.590

VandeWalle, D., \& Cummings, L. L. (1997). A Test of the Influence of Goal Orientation on the Feedback-Seeking Process. Journal of Applied Psychology, 82(3), 390-400.

Walker, A., \& Maltby, T. (2012). Active ageing: A strategic policy solution to demographic ageing in the European Union. International Journal of Social Welfare, 21, S117-S130. doi:10.1111/j.1468-2397.2012.00871.x

Warr, P. (2001). Age and work behaviour: physical attributes, cognitive abilities, knowledge, personality traits and motives. In C. L. Cooper \& I. T. Robertson (Eds.), International Review of Industrial and Organizational Psychology (pp. 1-36). London: Wiley Publishing.

Warr, P., \& Birdi, K. S. (1998). Employee age and voluntary development activity. International Journal of Training and Development, 2(3), 190-204. doi:10.1111/1468-2419.00047

Wittekind, A., Raeder, S., \& Grote, G. (2010). A Longitudinal Study of Determinants of Perceived Employability. Journal of Organizational Behavior, 31(4), 566-586. doi:10.1002/job.646 
Wrenn, K. A., \& Maurer, T. J. (2004). Beliefs About Older Workers' Learning and Development Behavior in Relation to Beliefs About Malleability of Skills, Age-Related Decline, and Control. Journal of Applied Social Psychology, 34(2), 223-242. doi:10.1111/j.1559-1816.2004.tb02546.x

Wright, P. M., \& Snell, S. A. (1998). Toward a Unifying Framework for Exploring Fit and Flexibility in Strategic Human Resource Management. Academy of Management Review, 23(4), 756-772.

Zacher, H., \& Frese, M. (2011). Maintaining a focus on opportunities at work: The interplay between age, job complexity, and the use of selection, optimization, and compensation strategies. Journal of Organizational Behavior, 32(1), 291-318. doi:10.1002/job.683

Zwick, T. (2011). Why Training Older Employees is Less Effective (No. 11-046). Mannheim: Centre for European Economic Research. 


\section{CHAPTER 3}

\section{Learning to Stay Employable*}

* This chapter is based on: Froehlich, D. E., Beausaert, S. A. J., Segers, M. S. R., \& Gerken, M. (2014). Learning to Stay Employable. Career Development International, 19(5), 508-525. doi:10.1108/CDI-11-2013-0139

Froehlich, D. E., Beausaert, S. A. J., \& Segers, M. S. R. (2013). Learning to Stay Employable: The Relationship between Age, Formal and Informal Learning, and Employability. Paper presented at the 15th biennial EARLI conference for research on learning and instruction. Munich. 


\section{AbStRACT}

The purpose of this chapter is to examine the effects of chronological age, formal learning, and informal learning from others on employability. Furthermore, indirect effects of age on employability via learning activities are tested. We conducted quantitative, cross-sectional survey research in three Dutch and Austrian organizations $(n=780)$ to study these relationships. Using structural equation modeling, we find that both formal learning and informal learning from others increase employees' employability. However, each type of learning contributes to different components of employability. Additionally, we find indirect effects of chronological age on employability via formal learning, but not via informal learning from others. This study contributes further evidence for the relationships of age and formal and informal learning on employability. Furthermore, it extends previous literature by examining different effects on different facets of employability, criticizing the prevalent use of chronological age, and investigating potential mediation effects. 


\section{INTRODUCTION}

The populations of many countries are aging (OECD, 2012) and people are required to stay longer in the workforce: to sustain national welfare systems, to help organizations thrive, and to pay their own bills. Consequently, governmental retirement policies (Billett, 2011) and organizational employment and retention policies (Colley, 2013) are being revised to encourage longer working lives and to combat the brain drain caused by the large number of senior workers retiring in the upcoming decade. This also puts strain on the individual employees, who are required to maintain their knowledge and flexibility in the context of new innovations. In this respect, scholars stressed the importance of employees' employability, i.e. the ability to identify and realize job and career opportunities (Fugate, Kinicki, \& Ashforth, 2004) due to a broad package of competencies, including occupational expertise, anticipation and optimization of the work environment, and personal flexibility (Van der Heijde \& Van der Heijden, 2006).

Research and public discourse about the effects of age on employability often elide the complexity of the relationship. There, chronological age takes a prominent role despite its poor predictive power with rising age due to the increased heterogeneity among individuals with higher age (Carstensen, 2006). Similarly, effects of chronological age are rarely specified in detail and potential mediators are mostly excluded from discussion. This is problematic, since age and aging are related to several spheres: physical and mental characteristics, social attributions, political agenda, etc.

While learning activities are needed to improve one's competencies and in turn employability (Van der Heijden, Boon, Van der Klink, \& Meijs, 2009), research on the relationship between learning and the maintenance and development of employees' employability is scarce (De Vos, De Hauw, \& Van der Heijden, 2011). Also, while the demographic shift increased interest in the role of chronological age in relationship to learning and employability, previous studies produced inconclusive results (see below). We investigate the effects of chronological age and activities of formal learning and informal learning from others on employability. Specifically, we conducted a quantitative survey study among 780 employees of two Austrian 
organizations and one Dutch institution to research the effects of chronological age and activities of formal learning and informal learning from others on employability.

\section{EMPLOYABILITY}

The concept of employability evolved over the last century and was dynamically adapted to the situation on the labor market. For instance, Gazier (1998, 2001, cited by McQuaid \& Lindsay, 2005) identified three waves of employability research. First, early in the 20th century, an absolute distinction between employable and unemployable based on whether one was able and willing to work was introduced. Second, in the 1950s and 1960s the perspective gradually shifted from focusing on the supply (i.e., ability and willingness to work) to also take into account the demand on the labor market. Third, the concept of employability was refined in the 1980s and 1990 s to eventually focus on three areas: the outcomes on the labor market, the individual's responsibility to develop and maintain transferable skills due to the increased prevalence of cross-organizational careers (D. T. Hall, 2004), and the relativity of employability in terms of both supply and demand on the labor market (Brown, Hesketh, \& Wiliams, 2003).

As business becomes more and more fast paced and the rate of innovation accelerates, job descriptions are constantly subject to change. This makes it increasingly inappropriate to define employability in terms of specific labor market demands. Instead, Van der Heijde and Van der Heijden (2006) suggest a conceptualization of employability that is based on a range of broad competencies. Hence we define individuals' employability as "the continuous fulfilling, acquiring or creating of work through the optimal use of competences" (Van der Heijde \& Van der Heijden, 2006, p. 453). In other words, the possession of certain competencies should allow employees to get, keep, or create work for themselves.

To become or stay employable, a package of competencies (Wright \& Snell, 1998), that includes social and adaptive competencies (Fugate et al., 2004; Rodriguez, Patel, Bright, Gregory, \& Gowing, 2002) on top of technical domain knowledge, needs to be considered. Technical and adaptive competencies are especially prevalent in public discourse and academic research (Ashford \& Taylor, 1990; De Cuyper, Bernhard-Oettel, Berntson, De 
Witte, \& Alarco, 2008; De Vos et al., 2011) and often targeted by stereotypes against older employees (Brownell \& Powell, 2013). Therefore, we focus on occupational expertise (technical knowledge), anticipation and optimization (proactive, self-initiated screening and preparation for potential changes in job and career requirements and conditions), and personal flexibility (reactive adaptation and resilience to change) (Van der Heijde \& Van der Heijden, 2006). In other words, we see employees as employable if they not only have vast technical knowledge about their working domain, but also are attentive to contextual changes and resilient towards change imposed on them.

We are especially interested in how the employees themselves rate their employability (Fugate et al., 2004). This is in line with previous studies, which suggest that perceived employability is more important than potential employers' (equally subjective) rating, since employees act based on their own perceptions (Van Emmerik, Schreurs, De Cuyper, Jawahar, \& Peeters, 2012). Similarly, Kinnunen et al. (2011) argue that the importance of selfappraised employability can be inferred from Lazarus and Folkman's (1984) transactional stress theory: employees who perceive themselves as highly employable feel less threatened by the environment, experience less strain (Berntson \& Marklund, 2007), and perform better (Kinnunen et al., 2011).

\section{ACTIVITIES OF FORMAL LEARNING AND INFORMAL LEARNING FROM OTHERS}

Van der Heijden et al. (2009) argue that learning is essential for enhancing one's employability. Likewise, Crouse, Doyle, and Young (2011) find several positive outcomes of learning, such as confidence, openness for change, and competence, when interviewing HR professionals. De Vos et al. (2011), too, find that employee participation in competency development initiatives positively affects their self-perceived employability in their study among 561 employees of a large financial institution in Belgium.

While learning may happen formally, i.e. inside a structure deliberately created for that purpose, it is especially informal learning that has recently received a lot of attention. Informal learning is less structured, more in control of the learner, often a by-product of some other activity, and happening unconsciously (Livingstone, 2001; Marsick \& Watkins, 2001; 
Mulder, 2013). Several studies suggest that informal learning is a more efficient form of learning than traditional formal learning offered through trainings and seminars (Berings, Poell, \& Simons, 2008; Billett, 2002; Eraut, 2007; Gorard, Fevre, \& Rees, 1999; Van der Heijden et al., 2009). As these two forms are opposing ends on a continuum (Eraut, 2004), we take both into account simultaneously.

Formal learning includes all designed learning that happens in a structured context and that may lead to formal recognitions, such as diplomas or certificates (Colardyn \& Bjornavold, 2004). In-company trainings, seminars, and workshops are examples of such formal learning activities. Empirical research finds that undertaking formal learning activities contributes to one's employability. For instance, Groot and Van den Brink (2000) have studied the effects of education and training on employability among Dutch employees and find positive effects. Sanders and De Grip's (2004) study among low-skilled workers confirms a positive effect of formal training on intra-firm employability, but does not find any effect of training on external employability. Van der Heijden and colleagues (2009) report positive relationships between formal learning and occupational expertise and anticipation and optimization. These consistent findings suggest formal learning to positively affect employability.

Hypothesis 1: Formal learning positively affects employability in terms of

occupational expertise, anticipation and optimization, and personal flexibility.

Eraut (2004) distinguishes implicit, reactive, and deliberative informal learning. Implicit learning is unconscious and not recognized by the learners themselves. Eraut (2004) argues that learning from experience mostly has such an implicit component - for example during the process for (workplace) socialization. Reactive learning is more conscious. This learning is intended and has a component of reflection. However, it happens in midst of some other activity and therefore receives only partial attention. Deliberate learning happens in work situations where time is specifically allotted for learning (Tynjälä, 2012). Eraut (Eraut, 2007) identifies encounters and relationships at work and opportunities for receiving feedback and support as important factors for learning at work. Additionally, he mentions participation in group activities, work alongside others, and consultations 
among the activities most conducive for learning. Similarly, Bamberger (2009) states that information-, feedback-, and help-seeking are important components of work-related informal learning from others. Since this indicates a high importance of the social component of workplace learning, we emphasize learning from others in this chapter.

Studies researching the link between informal learning and employability (and related concepts, such as career success (Cheramie, 2013)) often find a positive relationship. Van der Heijden et al. (2009) researched this relationship among non-academic university employees. They find informal networking within and outside their own organization (Bozionelos, 2003) to positively affect employees' employability. Feedbackseeking, i.e. the search for information targeted at evaluating and reflecting upon work processes and the self (Anseel, Lievens, \& Levy, 2007), has been related to positive outcomes such as goal attainment (Ammons, 1956) and performance (Kluger \& DeNisi, 1996). Van der Rijt et al. (2012) report feedback-seeking to affect perceived career development positively among employees in the financial sector in an early career stage. They note that it is especially the quality of feedback sought that positively impacts perceived career development - not so the mere frequency of feedback. These findings suggest a positive effect of informal learning from others on employability.

Hypothesis 2: Informal learning from others, i.e. information-seeking, feedbackseeking from the supervisor and from colleagues, and help-seeking, positively affects employability in terms of occupational expertise, anticipation and optimization, and personal flexibility.

\section{Chronological age, Learning, AND EMPLOYABiLITY}

Age is a very broad concept that may be viewed from different perspectives (Schalk et al., 2010). For instance, functional age, which is based on the ability of a person to perform certain tasks on a daily basis (Sharkey, 1987), psychological age, which refers to how old a person feels subjectively (Stephan, Demulier, \& Terracciano, 2012), organizational age, which is based on the tenure in the same organization, life-span age, which considers biological and societal factors in an integrative way and focuses on the roles 
people take during their lives (R. Schulz \& Heckhausen, 1996), or chronological age, which is a measure of time passed since birth.

Both in research and practice, chronological age is used most prominently. This is also true in research about employability, where chronological age is often included in the analyses - at least as a covariate. Many studies find negative relationships between age and employability (Raemdonck, Tillema, Grip, Valcke, \& Segers, 2012; Rothwell \& Arnold, 2007; Van der Heijden, 2002; Wittekind, Raeder, \& Grote, 2010) and related concepts, such as workability (Nielsen, 1999), career opportunities, and proactivity towards development (Van Veldhoven \& Dorenbosch, 2008). Contrarily, other studies present insignificant effects of age on occupational expertise, anticipation and optimization, and personal flexibility (Van der Heijden et al., 2009) or positive effects of age on self-perceived employability (Patrickson \& Ranzijn, 2003).

These inconsistent findings may hint at conceptual weaknesses of chronological age as a measure, which are often ignored. It hardly is chronological age per se that causes differences in employees' employability. Rather, these effects are often mediated by, for instance, effects attributable to a certain generation or period of time (B. H. Hall, Mairesse, \& Turner, 2007; Meriac, Woehr, Gorman, \& Thomas, 2013), stereotypes about age (Ahmed, Andersson, \& Hammarstedt, 2012), accumulated work experience. or, as we will argue, the involvement with activities of formal learning and informal learning from others. Chronological age per se is a weak predictor, given that people make different formative experiences throughout their lives and therefore become more heterogeneous the older they get (Carstensen, 2006; Staudinger \& Bowen, 2011). Consequently, the predictive value of age diminishes. Despite these shortcomings, both practitioners and researchers often use chronological age as an easy to measure proxy for the physical, cognitive, social, and emotional changes associated with human development (Pitt-Catsouphes, Matz-Costa, \& Besen, 2009) without making clear hypotheses how this effect can be explained.

With respect to the relation between age and formal learning, most studies indicate that older people are less interested in attending formal trainings (Kanfer \& Ackerman, 2004; Livingstone, 1999; Warr \& Birdi, 1998; 
Warr, 2001) and also are offered fewer opportunities to do so (Grima, 2011; Urwin, 2006; Van Vianen, Dalhoeven, \& De Pater, 2011). This negative relationship may be explained by negative stereotypes against older workers (Kunze, Boehm, \& Bruch, 2013; Maurer, Wrenn, \& Weiss, 2003; Wrenn \& Maurer, 2004) and by financial considerations, as the potential payoff period for any investments in employees is shorter the closer the employee is to retirement age.

Findings of studies researching a link between chronological age and informal learning from others are inconclusive. Specifically, while Tikkanen (2002) and Gupta et al. (1999) find a decreased use of informal learning and feedback-seeking among older workers, respectively, and Van der Heijden et al. (2009) note decreasing networking activity with increasing age, Livingstone (1999) finds "that [older people] spend nearly as much time on informal learning as middle-aged adults" (p. 13). Schulz and StamovRoßnagel (2010), too, find no significant difference between different ages in their sample of 470 employees of a German mail-order firm and argue that "[i]nformal learning might offer more opportunities to compensate for cognitive ageing effects so that negative age differences might disappear" ( $p$. 395). Indeed, Berg and Chyung (2008) find a positive correlation between age and engagement in informal learning when surveying 125 workplace learning and performance improvement professionals. Kyndt, Dochy, and Nijs (2009) find that younger employees (20 - 29 years) receive the fewest opportunities for feedback and knowledge acquisition (e.g., from work groups, project teams, guest speakers). Conversely, middle aged employees (30 - 39 years) get the most opportunities for feedback and knowledge acquisition. Interestingly, when it comes to acquiring information, the oldest employees score higher and the middle aged employees score the lowest.

It appears that there is a decisive difference between formal learning and informal learning from others when it comes to their role in the relationship between chronological age and employability. When seeking information, feedback and help from others, individuals are more in control of their own learning effort (Marsick \& Watkins, 2001) and less dependent on their employers' resources or others' stereotypes. Thereby employees are also more independent of the negative age effects mentioned above. Furthermore, it is important to note that after continuous confrontation with 
ageism, also the older employees themselves may accept these stereotypes as true (Kunze et al., 2013). While this may lead to a lower performance in formal training situations, this might not be the case for informal learning from others, as they are often not even perceived as learning by the learners themselves (Eraut, 2004, p. 249). Thus the negative self-perceptions of one's intellectual capabilities might be circumvented.

We aim to contribute further evidence for the relationship between chronological age and employability. In extension of the literature, we hypothesize that formal learning is a mediator that conveys negative indirect effects of chronological age on employability. Since employees are less dependent on employers' resources when learning informally, we do not propose such an indirect effect via informal learning from others.

Hypothesis 3: Chronological age negatively affects occupational expertise, anticipation and optimization, and personal flexibility indirectly via formal learning but not via informal learning from others.

In sum, the conceptual model includes chronological age, activities of formal learning and informal learning from others, and employability (Figure 1).

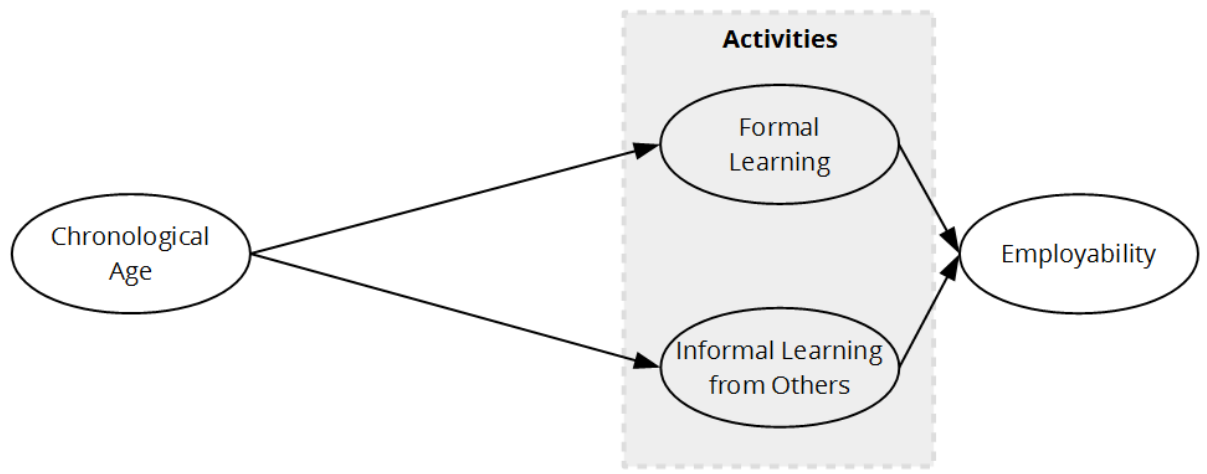

Figure 1: Research model of this chapter. 


\section{MetHODS}

\section{Procedure and participants}

We conducted studies in three organizations: a Dutch educational institution, an Austrian federal chamber, and an Austrian IT company. In collaboration with the respective Human Resource Departments, we adapted the questionnaires to the specific settings of the organizations. 4,153 employees were asked to participate in the online survey in September to December 2012. 814 (20\%) questionnaires were returned, of which 780 (19\%) were complete and used for further analyses: 613 of the Dutch educational institution, 90 of the Austrian chamber, and 77 of the Austrian IT company. The response rates of the latter two organizations (75\% and 50\%, respectively) exceed or match the average response rates found in comparable web based surveys (Baruch \& Holtom, 2008; Cook, Heath, \& Thompson, 2000) while the response rate of the Dutch educational institution (16\%) is lower. However, a wave analysis (i.e., a comparison of early and late respondents (Rogelberg \& Stanton, 2007)) found no statistical differences for the employability scales. This result gives us confidence that the results are not skewed by non-response bias, especially when considering the generally lower response rates for web surveys and surveys in the education sector (Baruch \& Holtom, 2008).

The respondents were 18 to 69 years old $(M=40.66, S D=11.19)$ and were on average $3.92(S D=4.65)$ years on their current job. $643(82 \%)$ have attained a higher education degree, 462 (59\%) were female.

\section{Instruments}

We gauged the three dimensions of employability - occupational expertise, anticipation and optimization, and personal flexibility - using Van der Heijde and Van der Heijden's (2006) items. Respondents answered on a 5-point Likert-scale (1 = almost never, 5 = very often); these self-reports are in line with our conceptualization of self-appraised employability. While we confirmed the original factor structure on an item level (RMSEA $=0.06, \chi^{2} / \mathrm{df}$ $=3.47, \mathrm{CFI}=0.90, \mathrm{TLI}=0.88$ ) and achieved satisfactory Cronbach's alphas ( $\mathrm{a}$ $=0.77$ to 0.92 , see Table 1 ) and Guttman's lambdas ( $\lambda 2=0.78$ to 0.92 ), we randomly assigned each item to one of three parcels per dimension to achieve a better relation between the number of parameters and the given 
sample size in the further analyses (Little, Cunningham, Shahar, \& Widaman, 2002). This model achieved an even better fit (RMSEA $=0.04, \chi^{2} / \mathrm{df}=2.30, \mathrm{CFI}$ $=0.99, \mathrm{TLI}=0.98$ ).

Respondents were asked about the days spent in formal learning activities in the last year. To aid memory, they had to base their answer on various types of learning activities (e.g., hours spent on conferences or hours spent in seminars), of which the sum was calculated.

Several kinds of informal learning from others were tested: information-seeking, feedback-seeking from the supervisor and from colleagues, and help-seeking. The respective subscales of Froehlich et al. (2014) informal learning from others questionnaire were used. Respondents answered on a 5-point Likert-scale ( $1=$ almost never, $5=$ very often). The factor structure of the scales was confirmed (RMSEA $=0.05, \chi^{2} / \mathrm{df}=2.93, \mathrm{CFI}=0.98, \mathrm{TLI}=0.97$ ) and satisfactory reliability was achieved ( $\alpha=0.66$ to $0.86 ; \lambda 2=0.66$ to 0.86 ).

Furthermore, we included several personal and contextual variables, which have been previously found to affect employability. This includes chronological age, gender, highest level of education, and years of experience on the current job (Mancinelli, Mazzanti, Piva, \& Ponti, 2010; Watson \& Grant, 2012; Wittekind et al., 2010). Since we noticed large differences of years of experience on the current job among the organizations, we assigned the cases to groups based on their experience relative to the rest of the sample. Specifically, we formed three groups (low experience, medium experience, high experience) based on the $33,33 \%$ and $66,66 \%$ percentile for each sample, and then grouped the cases with low experience, medium experience, and high experience together.

\section{Analyses}

First, we checked and confirmed the normality and homogeneity of variance assumptions for the dataset. Second, we explored the relations between the variables in bivariate correlation analyses. Third, we tested the hypotheses using structural equation modeling using Maximum Likelihood estimation in Mplus 7 (Muthén \& Muthén, 2012). The dataset does not contain any missing data. 


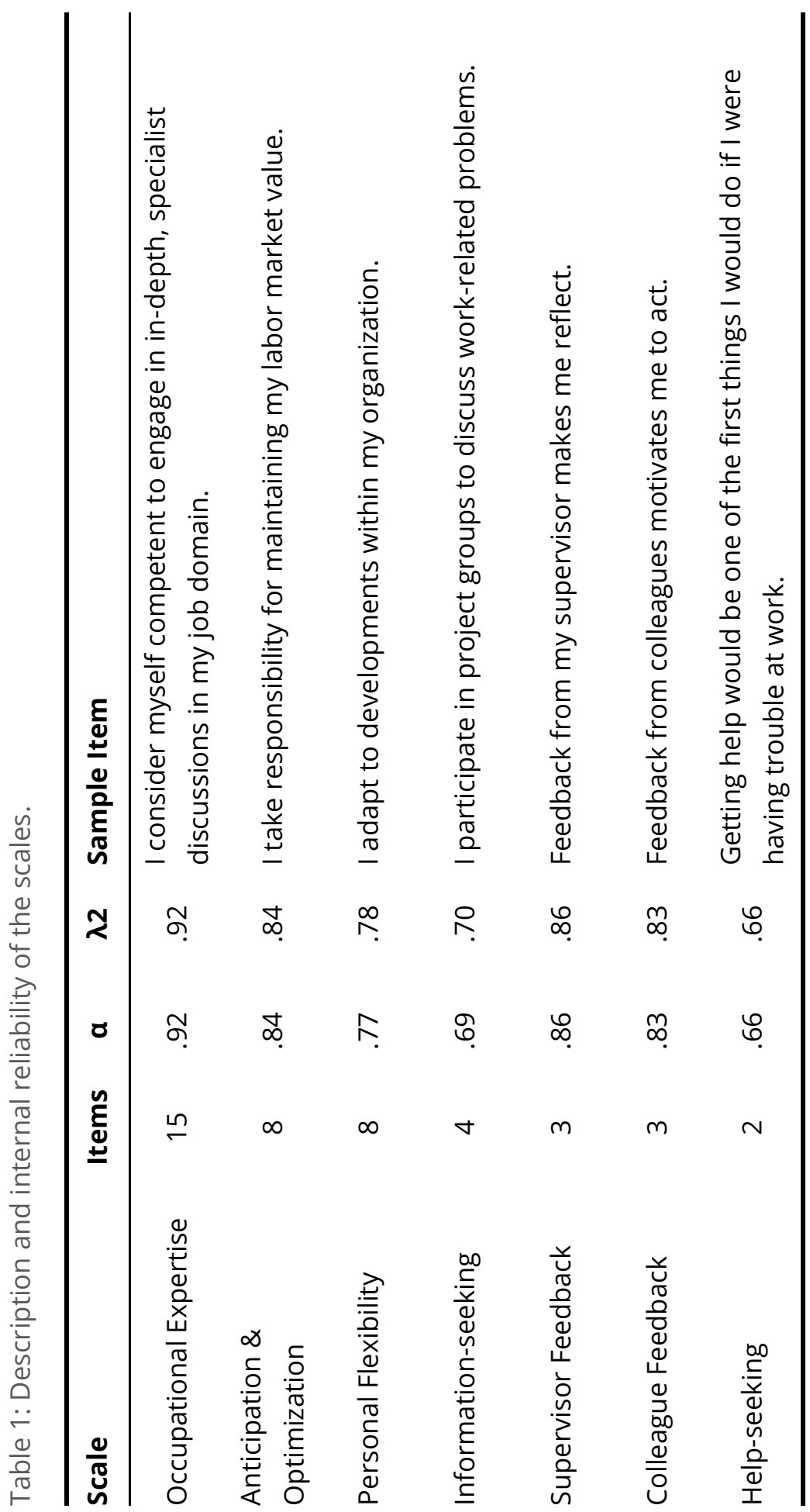




\section{RESULTS}

Table 2 shows strong intercorrelations among the dimensions of employability $(r=0.44, p<0.01$ to $r=0.53, p<0.01$ ) and positive correlations between them and measures of activities of formal learning and informal learning from others. This indicates that employees, who, for instance, believe to have wide occupational expertise, also perceive themselves to be flexible in adjusting to changes in their work or their environment. This could be caused by their information-, feedback-, and help-seeking behavior, which correlates positively with all dimensions of employability.

The correlation analyses also show effects of chronological age on both employability and actual learning behavior. Chronological age correlates positively with occupational expertise $(r=0.21, p<0.01)$ and personal flexibility $(r=0.09, p<0.05)$, but negatively with anticipation and optimization $(r=-0.11, p<0.01)$. Furthermore, chronological age is negatively correlated to formal learning $(r=-0.10, p<0.01)$ and feedbackseeking from the supervisor $(r=-0.25, p<0.01)$ and from colleagues $(r=-$ $0.09, \mathrm{p}<0.01)$.

We performed one-way analyses of variance (ANOVA) and found significant differences for all dimensions of employability (occupational expertise $F(2,777)=54.42, p<0.01$; anticipation and optimization $F(2,777)=$ $26.65, p<0.01$; personal flexibility $F(2,777)=11.53, p<0.01)$. The following analyses and interpretations need to take into account these differences among the samples. 
CHAPTER 3 | 73

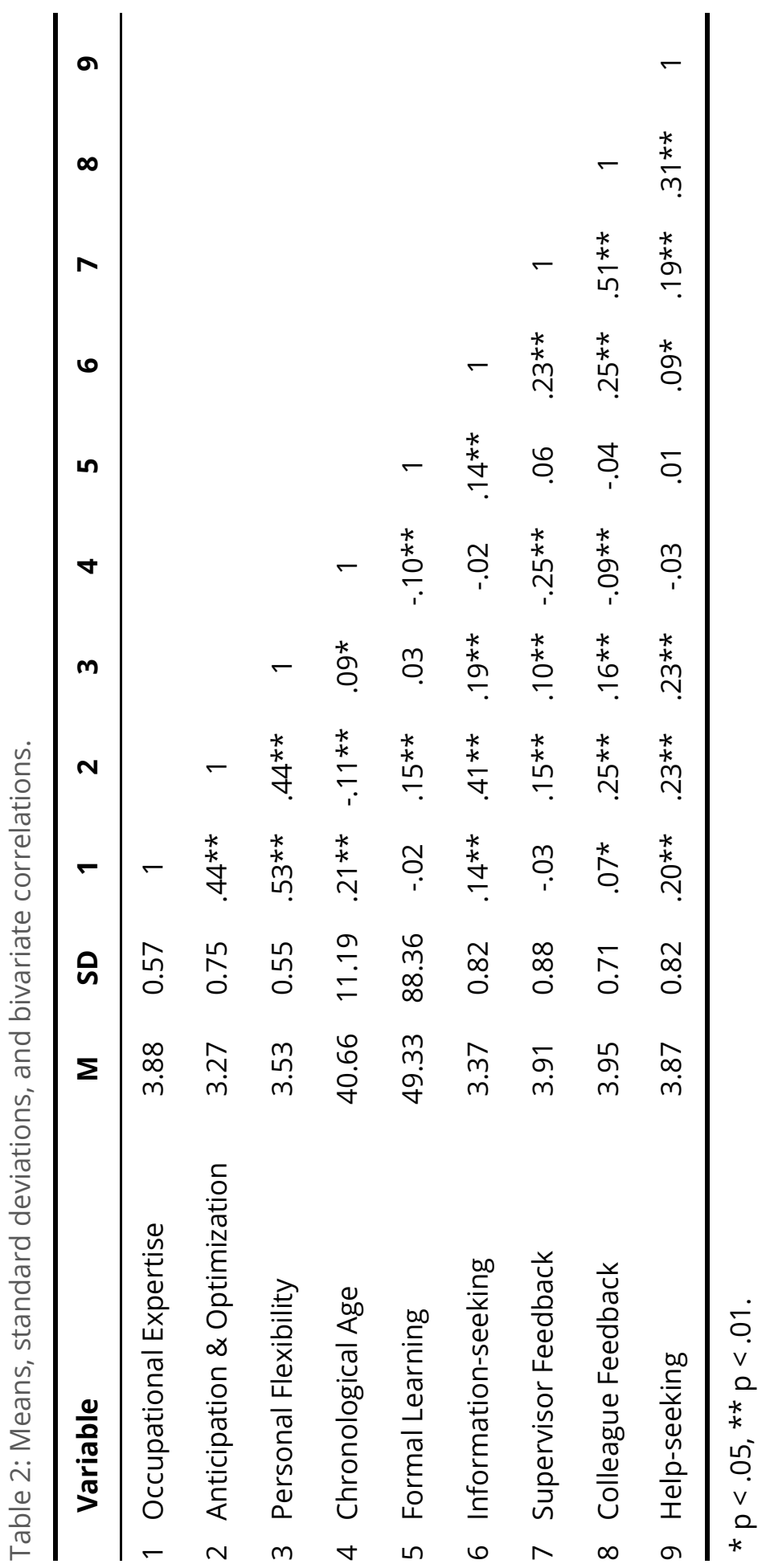


The structural equation modeling analyses show good model fit (Byrne, 2010; Hu \& Bentler, 1999): $\chi^{2} / \mathrm{df}=3.23$, RMSEA $=0.05, \mathrm{TLI}=0.90$ and $\mathrm{CFI}=0.93$ (see Tables 3 and 4 for the measurement and structural model, respectively, and Figure 2 for a visual overview over the model). In partial support of Hypothesis 1 , we find a positive effect of formal learning on anticipation and optimization $(\beta=0.15, p<0.01)$. Furthermore, we find $a$ positive effect of feedback-seeking from colleagues on anticipation and optimization $(\beta=0.22, p<0.01$ ). Help-seeking affects all three dimensions of employability (occupational expertise: $\beta=0.13, p<0.01$; anticipation and optimization: $\beta=0.13, p<0.05$; personal flexibility: $\beta=0.21, p<0.01$ ) while information-seeking affects anticipation and optimization $(\beta=0.49, p<$ $0.01)$, personal flexibility $(\beta=0.18, p<0.01)$, and to a weaker extent also occupational expertise $(\beta=0.07, p<0.10)$. This largely supports Hypothesis 2.

We find significant direct effects of chronological age on occupational expertise $(\beta=0.18, p<0.01)$ and personal flexibility $(\beta=0.21, p$ $<0.01)$. Furthermore, results show one negative indirect effect of chronological age on anticipation and optimization via formal learning ( $\beta=$ $0.01, p<0.05)$. This partially supports Hypothesis 3 .

Outside our main model of investigation, we find that the organization, the level of education, and the relative job experience play a significant role for employability. Specifically, the employing organization explains differences in occupational expertise and anticipation and optimization. The level of education has a negative effect on all dimensions of employability: occupational expertise $(\beta=-0.09, p<0.05)$, anticipation and optimization $(\beta=-0.14, p<0.01)$, and personal flexibility $(\beta=-0.10, p<0.05)$. Relative job experience affects occupational expertise positively $(\beta=0.12, p$ $<0.01$ ). These effects will be discussed in the next section. 
Table 3: Measurement model.

\begin{tabular}{lccc}
\hline Latent Variable & Item/Parcel & $\boldsymbol{\beta}$ & SE \\
\hline Colleagues Feedback & 1 & .88 & .02 \\
& 2 & .87 & .02 \\
Supervisor Feedback & 3 & .66 & .02 \\
& 1 & .88 & .01 \\
Help-seeking & 2 & .88 & .01 \\
Information-seeking & 3 & .73 & .02 \\
& 1 & .71 & .05 \\
& 2 & .71 & .05 \\
Occupational Expertise & 1 & .63 & .03 \\
& 2 & .39 & .04 \\
Anticipation \& Optimization & 3 & .86 & .03 \\
& 4 & .46 & .03 \\
Personal Flexibility & 1 & .76 & .02 \\
& 2 & .81 & .02 \\
& 3 & .91 & .02 \\
& 1 & .78 & .02 \\
& 2 & .77 & .02 \\
& 3 & .70 & .02 \\
& 1 & .63 & .03 \\
& 2 & .75 & .03 \\
& 3 & .59 & .03 \\
\hline
\end{tabular}


Table 4: Structural model showing standardized path coefficients.

\begin{tabular}{|c|c|c|c|}
\hline & $\begin{array}{l}\text { Occupational } \\
\text { Expertise }\end{array}$ & $\begin{array}{c}\text { Anticipation \& } \\
\text { Optimization }\end{array}$ & $\begin{array}{l}\text { Personal } \\
\text { Flexibility }\end{array}$ \\
\hline Organization 2 & $.29 * \star$ & $.11 *$ & .02 \\
\hline Organization 3 & $.19 * \star$ & .05 & -.03 \\
\hline Gender & .05 & .01 & .00 \\
\hline Job Experience & $.12 * \star$ & -.07 & -.05 \\
\hline Education Level & $-.09 *$ & $-.14 * \star$ & $-.10 *$ \\
\hline Chronological Age & $.18^{\star \star}$ & -.05 & $.21 * \star$ \\
\hline Formal Learning & .06 & $.15^{\star \star}$ & .06 \\
\hline Information-seeking & .07 & $.49 * \star$ & $.18 * \star$ \\
\hline Supervisor Feedback & -.01 & -.09 & .01 \\
\hline Colleague Feedback & .06 & $.22 * \star$ & .09 \\
\hline Help-seeking & $.13^{\star \star}$ & $.13^{*}$ & $.21 * \star$ \\
\hline
\end{tabular}

* $p<.05 ; * \star p<.01$. 


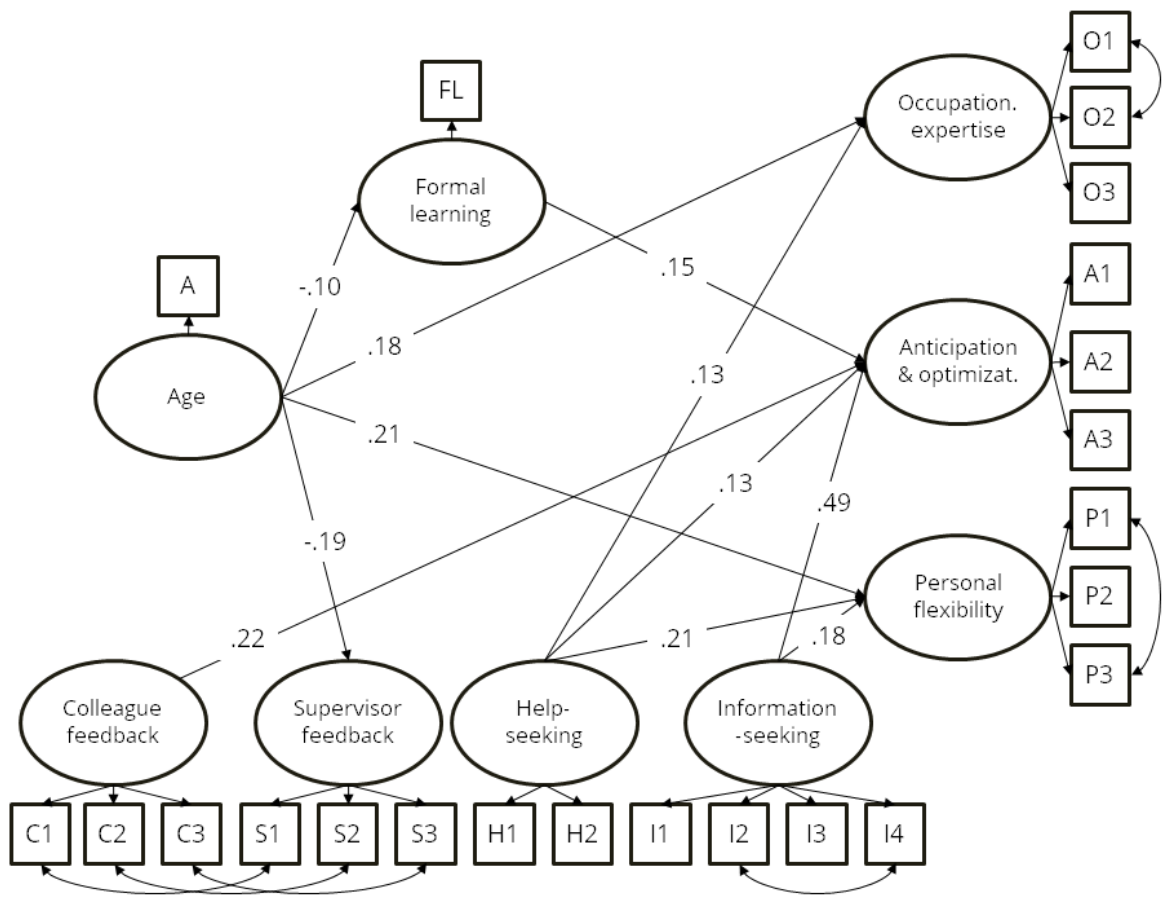

Figure 2: Overview over the model with standardized path coefficients (Insignificant relationships and covariates are hidden to improve readability.).

\section{Discussion}

Fueled by the increasing presence of interorganizational careers, the demographic shift, and the high rate of innovation, employability - and its relationship to age - is high on the agenda of human resource managers. We argue that it not the employees' chronological age per se that makes the difference in employability. Instead, we propose that the actual undertaking of activities of formal learning and informal learning from others has substantial effects. Therefore, we set out to research the effects of activities of formal learning and informal learning from others and chronological age on occupational expertise, anticipation and optimization, and personal flexibility. The results allow two broad conclusions. First, the undertaking of learning activities increases one's employability. While we found formal learning to affect especially anticipation and optimization positively, informal learning from others such as information- and help-seeking 
contribute to all three dimensions: occupational expertise, anticipation and optimization, and personal flexibility. Feedback-seeking from colleagues only affects anticipation and optimization. In sum, it is important to note that while both formal learning and informal learning from others may be functional to improve overall employability, there still might be differences in terms of specific learning contents. For example, the finding that formal learning affects predominantly anticipation and optimization might indicate that formal learning activities are especially well suited to learn about new domains. Informal learning from others, for which also effects on occupational expertise and personal flexibility were found, may subsequently be efficient for further developing knowledge, skills, and abilities.

Second, we found evidence for indirect effects of chronological age on employability via formal learning activities. This is in line with previous reports of negative effects of chronological age on the undertaking of formal learning activities (Kanfer \& Ackerman, 2004; Warr, 2001) and positive effects of formal learning activities on employability (Groot \& Van den Brink, 2000; Sanders \& De Grip, 2004; Van der Heijden et al., 2009). One reason for the reduced participation in formal learning activities of older employees is the unwillingness of employers to send older people to trainings (Grima, 2011; Van Vianen et al., 2011), often due to non-inclusive and discriminatory employer attitudes and policies (Billett \& Van Woerkom, 2008). Informal learning from others, however, is less dependent on the employers' resources and we did not find information-, feedback-, and help-seeking to mediate the relationship between chronological age and employability. When considering the strength of effects on employability of informal learning from others relative to those of formal learning, this suggests that informal learning from others is important especially for older employees to maintain their employability.

Next to the findings in our main model under investigation, we found relative experience on the current job to affect occupational expertise positively. This is in line with the notion that experience is a key component for developing expertise (Ericsson, 2006).

We included three organizations that are located in different countries, sectors, and cultures. This allows us to make statements that are 
more generalizable than research conducted in one sample only. However, the analyses revealed that there are differences between the participating organizations and our level of analysis does not allow us to work out what factors exactly make the difference. For instance, it is probable that the competencies needed to accomplish the tasks in the Austrian chamber, which mainly concern the consolidation of diverging interests within the setting of a fast moving economy, are different to the competencies required to sell IT solutions and give consulting on them, as needed in the IT organization. Therefore, task characteristics, such as task complexity (Campbell, 1988), may play a role. However, since these organizations are embedded in different regulatory, cultural, and linguistic environments, the data collected are not sufficient to investigate the differences more deeply further research is required to address this topic of contextual differences.

We found negative effects of education on employability. This is unexpected, as employability is often mentioned as a goal of education efforts (Herr, 1987; Knight \& Yorke, 2002), However, our specific sample is already very highly educated $-82 \%$ of the respondents had obtained a higher education degree. In this case, higher education may also mean a very high level of specialization, and consequently less flexibility on the labor market. Future research could explore a potentially curvilinear relationship between these concepts.

The self-reported scores of learning activities and employability may raise concerns about common method variance (Podsakoff \& Organ, 1986). However, since self-appraised employability scores are well supported by theory and empirical evidence (Kinnunen et al., 2011; Van Emmerik et al., 2012) and all instruments used showed high construct validity, we are confident that our approach is appropriate (Conway \& Lance, 2010). Nevertheless, future research may use different methods and different sources. After all, previous research found employees to rate themselves higher than their employers (Van der Heijde \& Van der Heijden, 2006) and higher than their labor market success would suggest (Patrickson \& Ranzijn, 2003).

Furthermore, unlike most preceding research, we focused on formal learning and informal learning from others simultaneously. However, learning is a broad concept and we necessarily had to focus on specific 
forms of learning only. We focused on informal learning in a social context (i.e., information-, feedback-, and help-seeking) and ignored other facets, such as the learning value of the job itself, which has previously been found to play an important role (Van der Heijden \& Bakker, 2011). While we are confident that our measurement of formal learning activities gives adequate information to assess our hypotheses, it is possible that other features than the mere quantity of formal learning activities have an effect. Future research could close this gap by studying the relationships between other forms and measures of formal and informal learning, age, and employability. In a similar vein, the inconclusive relationship between informal learning and employability still needs consideration and clarification in future research.

\section{IMPLICATIONS AND CONCLUSIONS}

The evidence found calls once more for closer examination of stereotypes against older employees and questions the predominant use of chronological age as decisive criterion in organizational and national policies. In the recent public debate about retirement age and other workplace-related discussions, chronological age plays a much more prominent role than the findings presented here suggest it should. Based on the findings, we recommend to step back from this one-sided practice and to look at other, more predictive factors, too. Furthermore, the results advocate increased education against age stereotypes - not only to generate a level playing field between different age groups, but also to increase the self-confidence of older employees. After all, increased employability is not only beneficial for the individual employee, but for the employing organization as well (Van der Heijde \& Van der Heijden, 2006).

Findings show that formal learning and especially informal learning from others improve one's employability - with all the associated benefits for the individual and the employing organization (Arocena, Núñez, \& Villanueva, 2006). This suggests that learning should be supported and stimulated for employees - irrespective of their chronological age. For individuals it is especially important to be aware about the strong effects of informal learning from others on their employability. The effects on employability are not only stronger compared to those of formal learning, 
but while the employer's consent may be needed to spend money and time to attend formal learning activities, the employees themselves are in greater control when it comes to informal learning from others.

From an employers' perspective it is crucial to understand the consequences of limiting older employees' access to formal learning activities. In our fast paced business world, learning activities are required to maintain - not only to develop - employability. In general, both researchers and practitioners are reminded and encouraged to investigate the supposedly direct effects of chronological age with greater scrutiny. Relying on weak predictors such as chronological age may lead to unwanted consequences - especially in times of the demographic shift.

While we discussed the implications on the individual and organizational level, it is important to also note the implications for policy. The age dependency ratio, which relates the number of people outside the active workforce to the working age population, is expected to rise significantly within the next decade. It is therefore essential to increase older employees' employability and participation in the labor market to maintain the current standard of living (Ilmarinen, 2001). The recommendations to combat ageism, to support formal learning and informal learning from others, and to be more reflective on the use of chronological age in general are therefore also applicable on the level of national and international policy. 


\section{REFERENCES}

Ahmed, A. M., Andersson, L., \& Hammarstedt, M. (2012). Does age matter for employability? A field experiment on ageism in the Swedish labour market. Applied Economics Letters, 19(4), 403-406. doi:10.1080/13504851.2011.581199

Ammons, R. B. (1956). Effects of Knowledge of Performance: A Survey and Tentative Theoretical Formulation. Journal of General Psychology, 54(2), 279-299. doi:10.1080/00221309.1956.9920284

Anseel, F., Lievens, F., \& Levy, P. E. (2007). A Self-motives Perspective on Feedback-seeking Behavior: Linking Organizational Behavior and Social Psychology Research. International Journal of Management Reviews, 9(3), 211-236. doi:10.1111/j.1468-2370.2007.00210.x

Arocena, P., Núñez, I., \& Villanueva, M. (2006). The Effect of Enhancing Workers' Employability on Small and Medium Enterprises: Evidence from Spain. Small Business Economics, 29(1-2), 191-201. doi:10.1007/s11187-006-6712-7

Ashford, S. J., \& Taylor, M. S. (1990). Adaptationto work transitions: An integrative approach. In G. R. Ferris \& K. M. Rowland (Eds.), Research in personnel and human resource management (Vol. 8, pp. 1-39). Greenwich, CT: JAI Press.

Bamberger, P. A. (2009). Employee Help-Seeking: Antecedents, Consequences and new Insights for Future Research. In J. J. Martocchio \& H. Liao (Eds.), Research in Personnel and Human Resource Management (Vol. 28, pp. 49-98). Bingley: Emerald Group Publishing. doi:10.1108/S0742-7301(2009)0000028005

Baruch, Y., \& Holtom, B. C. (2008). Survey Response Rate Levels and Trends in Organizational Research. Human Relations, 61(8), 1139-1160. doi:10.1177/0018726708094863

Berg, S. A., \& Chyung, S. Y. (2008). Factors that influence informal learning in the workplace. Journal of Workplace Learning, 20(4), 229-244. doi:10.1108/13665620810871097 
Berings, M. G. M. C., Poell, R. F., \& Simons, P. R.-J. (2008). Dimensions of Onthe-Job Learning Styles. Applied Psychology: An International Review, 57(3), 417-440. doi:10.1111/j.1464-0597.2008.00362.x

Berntson, E., \& Marklund, S. (2007). The Relationship Between Employability and Subsequent Health. Work \& Stress, 21(3), 279-292. doi:10.1080/02678370701659215

Billett, S. (2002). Towards a Workplace Pedagogy: Guidance, Participation and Engagement. Adult Education Quarterly, 53(1), 27-43. doi:10.1177/074171302237202

Billett, S. (2011). Promoting Lifelong Employability for Workforce Aged Over 45: Singaporean Workers' Perspectives. International Journal of Continuing Education and Lifelong Learning, 3(2), 57-73.

Billett, S., \& Van Woerkom, M. (2008). Personal Epistemologies and Older Workers. International Journal of Lifelong Learning, 27(3), 333-348.

Bozionelos, N. (2003). Intra-Organizational Network Resources: Relation to Career Success and Personality. International Journal of Organizational Analysis, 11(1), 41-66.

Brown, P., Hesketh, A., \& Wiliams, S. (2003). Employability in a Knowledgedriven Economy. Journal of Education and Work, 16(2), 107-126. doi:10.1080/1363908032000070648

Brownell, P., \& Powell, M. S. W. (2013). Definitions and Theoretical Models for Understanding Ageism and Abuse in the Workplace. In P. Brownell \& J. J. Kelly (Eds.), Ageism and Mistreatment of Older Workers: Current Reality, Future Solutions (pp. 17-28). New York: Springer.

Byrne, B. M. (2010). Structural Equation Modeling with AMOS: Basic Concepts, Applications, and Programming (2nd ed.). New York, NY: Taylor \& Francis Group.

Campbell, D. J. (1988). Task Complexity: A Review and Analysis. Academy of Management Review, 13(1), 40-52.

Carstensen, L. L. (2006). The Influence of a Sense of Time on Human Development. Science, 312(5782), 1913-1915. doi:10.1126/science. 1127488 
Cheramie, R. (2013). An examination of feedback-seeking behaviors, the feedback source and career success. Career Development International, 18(7), 712-731. doi:10.1108/CDI-05-2013-0070

Colardyn, D., \& Bjornavold, J. (2004). Validation of Formal, Non-Formal and Informal Learning: policy and practices in EU Member States. European Journal of Education, 39(1), 69-89. doi:10.1111/j.01418211.2004.00167.x

Colley, L. (2013). Understanding Ageing Public Sector Workforces: Demographic challenge or a consequence of public employment policy design? Public Management Review, 16(7), 1030-1052. doi:10.1080/14719037.2013.771697

Conway, J. M., \& Lance, C. E. (2010). What Reviewers Should Expect from Authors Regarding Common Method Bias in Organizational Research. Journal of Business and Psychology, 25(3), 325-334. doi:10.1007/s10869010-9181-6

Cook, C., Heath, F., \& Thompson, R. L. (2000). A Meta-Analysis of Response Rates in Web- or Internet-Based Surveys. Educational and Psychological Measurement, 60(6), 821-836. doi:10.1177/00131640021970934

Crouse, P., Doyle, W., \& Young, J. D. (2011). Workplace Learning Strategies, Barriers, Facilitators and Outcomes: a Qualitative Study among Human Resource Management Practitioners. Human Resource Development International, 14(1), 39-55. doi:10.1080/13678868.2011.542897

De Cuyper, N., Bernhard-Oettel, C., Berntson, E., De Witte, H., \& Alarco, B. (2008). Employability and Employees' Well-Being: Mediation by Job Insecurity. Applied Psychology, 57(3), 488-509.

De Vos, A., De Hauw, S., \& Van der Heijden, B. I. J. M. (2011). Competency development and career success: The mediating role of employability. Journal of Vocational Behavior, 79(2), 438-447. doi:10.1016/j.jvb.2011.05.010

Eraut, M. (2004). Informal Learning in the Workplace. Studies in Continuing Education, 26(2), 247-273. doi:10.1080/158037042000225245

Eraut, M. (2007). Learning from Other People in the Workplace. Oxford Review of Education, 33(4), 403-422. doi:10.1080/03054980701425706 
Ericsson, K. A. (2006). The Influence of Experience and Deliberate Practice on the Development of Superior Expert Performance. In K. A. Ericsson, N. Charness, P. J. Feltovich, \& R. R. Hoffman (Eds.), The Cambridge Handbook of Expertise and Expert Performance (pp. 685-705). Cambridge: Cambridge University Press. doi:10.1017/CBO9780511816796.038

Froehlich, D. E., Beausaert, S. A. J., \& Segers, M. S. R. (2014). Informal Learning in a Social Context: Development and Validation of a Scale. Poster presented at the AERA Annual Meeting. Philadelphia. doi:http://dx.doi.org/10.6084/m9.figshare.1204862

Fugate, M., Kinicki, A. J., \& Ashforth, B. E. (2004). Employability: A psychosocial construct, its dimensions, and applications. Journal of Vocational Behavior, 65(1), 14-38. doi:10.1016/j.jvb.2003.10.005

Gorard, S., Fevre, R., \& Rees, G. (1999). The apparent Decline of Informal Learning. Oxford Review of Education, 25(4), 437-454. doi:10.1080/030549899103919

Grima, F. (2011). The influence of age management policies on older employee work relationships with their company. International Journal of Human Resource Management, 22(6), 1312-1332. doi:10.1080/09585192.2011.559101

Groot, W., \& Van den Brink, H. M. (2000). Education, training and employability. Applied Economics, 32(5), 573-581. doi:10.1080/000368400322471

Gupta, A. K., Govindarajan, V., \& Malhotra, A. (1999). Feedback-Seeking Behavior within Multinational Corporations. Strategic Management Journal, 20(3), 205-222.

Hall, B. H., Mairesse, J., \& Turner, L. (2007). Identifying age, cohort, and period effects in scientific research productivity: discussion and illustration using simulated and actual data on french physicists. Economics of Innovation and New Technology, 16(2), 37-41.

Hall, D. T. (2004). The protean career: A quarter-century journey. Journal of Vocational Behavior, 65(1), 1-13. doi:10.1016/j.jvb.2003.10.006 
Herr, E. L. (1987). Education as preparation for work: Contributions of career education and vocational education. Journal of Career Development, 13(3), 16-30. doi:10.1007/BF01351855

Hu, L., \& Bentler, P. M. (1999). Cutoff criteria for fit indexes in covariance structure analysis: Conventional criteria versus new alternatives. Structural Equation Modeling, 6(1), 1-55.

Ilmarinen, J. E. (2001). Aging Workers. Occupational and Environmental Medicine, 58(8), 546-552.

Kanfer, R., \& Ackerman, P. L. (2004). Aging, Adult Development, and Work Motivation. Academy of Management Review, 29(3), 440-458. doi:10.2307/20159053

Kinnunen, U., Mäkikangas, A., Mauno, S., Siponen, K., \& Nätti, J. (2011). Perceived employability: Investigating outcomes among involuntary and voluntary temporary employees compared to permanent employees. Career Development International, 16(2), 140-160. doi:10.1108/13620431111115604

Kluger, A. N., \& DeNisi, A. (1996). The Effects of feedback intervention on performance: A historical review, a meta-analysis, and a preliminary feedback intervention theory. Psychological Bulletin, 119(2), 254-284. doi:10.1037/0033-2909.119.2.254

Knight, P. T., \& Yorke, M. (2002). Employability through the curriculum. Tertiary Education and Management, 8(4), 261-276. doi:10.1080/13583883.2002.9967084

Kunze, F., Boehm, S. A., \& Bruch, H. (2013). Age, resistance to change, and job performance. Journal of Managerial Psychology, 28(7), 741-760. doi:10.1108/JMP-06-2013-0194

Kyndt, E., Dochy, F., \& Nijs, H. (2009). Learning Conditions for Non-Formal and Informal Workplace Learning. Journal of Workplace Learning, 21(5), 369-383. doi:10.1108/13665620910966785

Lazarus, R. S., \& Folkman, S. (1984). Stress, Appraisal, and Coping. New York: Springer.

Little, T. D., Cunningham, W. A., Shahar, G., \& Widaman, K. F. (2002). To Parcel or Not to Parcel: Exploring the Question, Weighing the Merits. 
Structural Equation Modeling, 9(2), 151-173. doi:10.1207/S15328007SEM0902_1

Livingstone, D. W. (1999). Exploring the icebergs of adult learning: Findings of the first Canadian survey of informal learning practices. Canadian Journal for the Study of Adult Education, 13(2), 49-72.

Livingstone, D. W. (2001). Adults' Informal Learning: Definitions, Findings, Gaps and Future Research (No. 21). Toronto, Ontario: Centre for the Study of Education and Work.

Mancinelli, S., Mazzanti, M., Piva, N., \& Ponti, G. (2010). Education, reputation or network? Evidence on migrant workers employability. Journal of Socio-Economics, 39(1), 64-71. doi:10.1016/j.socec.2009.08.002

Marsick, V. J., \& Watkins, K. E. (2001). Informal and Incidental Learning. New Directions for Adult and Continuing Education, 2001(89), 25-34. doi:10.1002/ace.5

Maurer, T. J., Wrenn, K. A., \& Weiss, E. M. (2003). Toward Understanding and Managing Stereotypical Beliefs about Older Workers' Ability and Desire for Learning and Development. In J. Martocchio (Ed.), Research in Personnel and Human Resources Management (Vol. 22, pp. 253-285). Bingley: Emerald Group Publishing. doi:10.1016/S0742-7301(03)220065

McQuaid, R. W., \& Lindsay, C. (2005). The concept of employability. Urban Studies, 42(2), 197-219. doi:10.1080/0042098042000316100

Meriac, J. P., Woehr, D. J., Gorman, C. A., \& Thomas, A. L. E. (2013). Development and validation of a short form for the multidimensional work ethic profile. Journal of Vocational Behavior, 82(3), 155-164. doi:10.1016/j.jvb.2013.01.007

Mulder, R. H. (2013). Exploring feedback incidents, their characteristics and the informal learning activities that emanate from them. European Journal of Training and Development, 37(1), 49-71. doi:10.1108/03090591311293284

Muthén, L. K., \& Muthén, B. O. (2012). MPlus. Los Angeles, CA: Muthén \& Muthén. 
Nielsen, J. (1999). Employability and Workability among Danish Employees. Experimental Aging Research, 25(4), 393-397.

OECD. (2012). OECD Environmental Outlook to 2050. Paris: OECD Publishing. doi:10.1787/9789264122246-en

Patrickson, M., \& Ranzijn, R. (2003). Employability of Older Workers. Equal Opportunities International, 22(5), 50-63. doi:10.1108/02610150310787496

Pitt-Catsouphes, M., Matz-Costa, C., \& Besen, E. (2009). Workplace Flexibility: Findings from the Age \& Generations Study. Issue Brief No. 19. Chestnut Hill, MA: Sloan Center on Aging \& Work at Boston College.

Podsakoff, P. M., \& Organ, D. W. (1986). Self-Reports in Organizational Research: Problems and Prospects. Journal of Management, 12(4), 531 544. doi:10.1177/014920638601200408

Raemdonck, I., Tillema, H. H., Grip, A., Valcke, M., \& Segers, M. S. R. (2012). Does Self-directedness in Learning and Careers Predict the Employability of Low-Qualified Employees? Vocations and Learning, 5(2), 137-151. doi:10.1007/s12186-011-9072-7

Rodriguez, D., Patel, R., Bright, A., Gregory, D., \& Gowing, M. K. (2002). Developing competency models to promote integrated human resource practices. Human Resource Management, 41(3), 309-324. doi:10.1002/hrm.10043

Rogelberg, S. G., \& Stanton, J. M. (2007). Introduction: Understanding and Dealing With Organizational Survey Nonresponse. Organizational Research Methods, 10(2), 195-209. doi:10.1177/1094428106294693

Rothwell, A., \& Arnold, J. (2007). Self-perceived employability: Development and validation of a scale. Personnel Review, 36(1), 23-41. doi:10.1108/00483480710716704

Sanders, J., \& De Grip, A. (2004). Training, Task Flexibility and Low-Skilled Workers' Employability. International Journal of Manpower, 25(1), 73-89. doi:10.1108/01437720410525009

Schalk, R., Van Veldhoven, M. J. P. M., De Lange, A. H., De Witte, H., Kraus, K., Stamov-Roßnagel, C., ... Zacher, H. (2010). Moving European Research on Work and Ageing Forward: Overview and Agenda. European Journal 
of Work and Organizational Psychology, 19(1), 76-101. doi:10.1080/13594320802674629

Schulz, M., \& Stamov-Roßnagel, C. (2010). Informal workplace learning: An exploration of age differences in learning competence. Learning and Instruction, 20(5), 383-399. doi:10.1016/j.learninstruc.2009.03.003

Schulz, R., \& Heckhausen, J. (1996). A life span model of successful aging. The American Psychologist, 51(7), 702-714.

Sharkey, B. J. (1987). Functional vs chronologic age. Medicine and Science in Sports and Exercise, 19(2), 174-178.

Staudinger, U. M., \& Bowen, C. E. (2011). A systemic approach to aging in the work context. Zeitschrift für ArbeitsmarktForschung, 44(4), 295-306. doi:10.1007/s12651-011-0086-2

Stephan, Y., Demulier, V., \& Terracciano, A. (2012). Personality, self-rated health, and subjective age in a life-span sample: The moderating role of chronological age. Psychology and Aging, 27(4), 875-880. doi:10.1037/a0028301

Tikkanen, T. (2002). Learning at work in technology intensive environments. Journal of Workplace Learning, 14(3), 89-97. doi:10.1108/13665620210421902

Tynjälä, P. (2012). Toward a 3-P Model of Workplace Learning: a Literature Review. Vocations and Learning, 6(1), 11-36. doi:10.1007/s12186-0129091-z

Urwin, P. (2006). Age discrimination: legislation and human capital accumulation. Employee Relations, 28(1), 87-97. doi:10.1108/01425450610633082

Van der Heijde, C. M., \& Van der Heijden, B. I. J. M. (2006). A competencebased and multidimensional operationalization and measurement of employability. Human Resource Management, 45(3), 449-476. doi:10.1002/hrm.20119

Van der Heijden, B. I. J. M. (2002). Prerequisites to guarantee life-long employability. Personnel Review, 31(1), 44-61. doi:10.1108/00483480210412418 
Van der Heijden, B. I. J. M., \& Bakker, A. B. (2011). Toward a Mediation Model of Employability Enhancement: A Study of Employee-Supervisor Pairs in the Building Sector. Career Development Quarterly, 59(3), 232-249. doi:10.1002/j.2161-0045.2011.tb00066.x

Van der Heijden, B. I. J. M., Boon, J., Van der Klink, M. R., \& Meijs, E. (2009). Employability Enhancement through Formal and Informal Learning: An Empirical Study among Dutch Non-Academic University Staff Members. International Journal of Training and Development, 13(1), 19-37. doi:10.1111/j.1468-2419.2008.00313.x

Van der Rijt, J., Van den Bossche, P., Van de Wiel, M. W. J., Segers, M. S. R., \& Gijselaers, W. H. (2012). The role of individual and organizational characteristics in feedback-seeking behaviour in the initial career stage. Human Resource Development International, 15(3), 283-301. doi:10.1080/13678868.2012.689216

Van Emmerik, I. J. H., Schreurs, B., De Cuyper, N., Jawahar, I. M., \& Peeters, M. C. W. (2012). The route to employability: Examining resources and the mediating role of motivation. Career Development International, 17(2), 104-119. doi:10.1108/13620431211225304

Van Veldhoven, M. J. P. M., \& Dorenbosch, L. (2008). Age, Proactivity and Career Development. Career Development International, 13(2), 112-131. doi:10.1108/13620430810860530

Van Vianen, A. E. M., Dalhoeven, B. A. G. W., \& De Pater, I. E. (2011). Aging and training and development willingness: Employee and supervisor mindsets. Journal of Organizational Behavior, 32(2), 226-247. doi:10.1002/job.685

Warr, P. B. (2001). Age and work behaviour: physical attributes, cognitive abilities, knowledge, personality traits and motives. In C. L. Cooper \& I. T. Robertson (Eds.), International Review of Industrial and Organizational Psychology (pp. 1-36). London: Wiley Publishing.

Warr, P. B., \& Birdi, K. S. (1998). Employee age and voluntary development activity. International Journal of Training and Development, 2(3), 190-204. doi:10.1111/1468-2419.00047 
Watson, C., \& Grant, C. (2012). Employability: The development and validation of a scale to measure work-related competencies. Assessment \& Development Matters, 4(3), 13-16.

Wittekind, A., Raeder, S., \& Grote, G. (2010). A Longitudinal Study of Determinants of Perceived Employability. Journal of Organizational Behavior, 31(4), 566-586. doi:10.1002/job.646

Wrenn, K. a., \& Maurer, T. J. (2004). Beliefs About Older Workers' Learning and Development Behavior in Relation to Beliefs About Malleability of Skills, Age-Related Decline, and Control. Journal of Applied Social Psychology, 34(2), 223-242. doi:10.1111/j.1559-1816.2004.tb02546.x

Wright, P. M., \& Snell, S. A. (1998). Toward a Unifying Framework for Exploring Fit and Flexibility in Strategic Human Resource Management. Academy of Management Review, 23(4), 756-772. 
92 | LEARNING to StAy EMPLOYABLE 


\section{CHAPTER 4 \\ Motivated to Stay Employable: The Effects of Age, Future Time Perspective, and Goal Orientation*}

* This chapter is based on: Froehlich, D. E., Beausaert, S. A. J., \& Segers, M. S. R. (Resubmitted). Motivated to stay employable: The effects of age, future time perspective, and goal orientation.

Froehlich, D. E., Beausaert, S. A. J., \& Segers, M. S. R. (2013). It's All about the Attitudes, not the Age: The Role of Future Time Perspective and Goal Orientation for Older Employees' Employability. Paper presented at the 15th biennial EARLI conference for research on learning and instruction. Munich. 


\section{Abstract}

The demographic shift and the rapid rate of innovations put age and employability high on policy makers' and human resource managers' agenda. However, we do not sufficiently understand the link between these concepts. We set out to investigate the relationship between age and employability and aim to identify motivational mediators of this relationship. Therefore, we investigate the roles of future time perspective and goal orientation. We conducted quantitative, cross-sectional survey research ( $n=$ 282) in three Dutch and Austrian organizations. We used structural equation modeling to investigate the relationships between chronological age, future time perspective, goal orientations, and employability. The evidence shows that future time perspective and goal orientation strongly relate to employability. Furthermore, we find indirect relationships between age and employability via perceived remaining opportunities. The results question the often simplistic use of chronological age in employability and human resource management research. This shifts the focus from age, a factor outside our control, to motivation. Thereby, the findings contribute new insights for the career development issues of an increasingly older workforce. 


\section{INTRODUCTION}

The population ages and people need to stay longer in the workforce (Bal, Kooij, \& Rousseau, 2015): to sustain national welfare systems, to help organizations thrive, and to pay their own bills. This challenges employees to be able to identify and realize job and career opportunities in the context of innovations - they need to stay employable (Fugate \& Kinicki, 2008). While policy makers and human resource managers often rely on chronological age for decisions about, for instance, the offering of part time work schemes or the default retirement age, this measure may not be very meaningful in the work setting (Kooij, de Lange, Jansen, \& Dikkers, 2008). After all, we become increasingly different from each other with higher age (Carstensen, 2006). One specific factor that is often suggested to be subject to change during the process of aging is the motivation to learn (Gegenfurtner \& Vauras, 2012). Therefore, we investigate the relationship between chronological age and employability using a motivational perspective (Froehlich, Beausaert, \& Segers, 2014). Specifically, we combine the concepts of future time perspective (Carstensen, 2006) and goal orientation (Elliot \& McGregor, 2001) with a competence-based view of employability (Van der Heijde \& Van der Heijden, 2006) to explain the relationship between age and employability.

\section{EMPLOYABILITY AND CHRONOLOGICAL AGE}

We define being employable as having a set of competences that enables people to fulfill, acquire, or create work (Van der Heijde \& Van der Heijden, 2006). In times of change, such a definition based on individuals' competences, rather than on specific labor market demands, seems warranted. Having the necessary occupational expertise is important, but employability also requires social and adaptive competences (Tolentino et al., 2014). Employees need to proactively screen the environment and prepare themselves for changes in job and career requirements and conditions (anticipation and optimization) and adapt to them (personal flexibility) (Van der Heijde \& Van der Heijden, 2006). In agreement with previous studies, we focus on employees' own perceptions of their employability (Dries, Forrier, De Vos, \& Pepermans, 2014; Froehlich, Beausaert, Segers, \& Gerken, 2014; Vanhercke, De Cuyper, Peeters, \& De 
Witte, 2014). In conclusion, we see employees as employable if they perceive themselves to have adequate technical expertise, to be attentive to trends in their environment, and to adapt to changes imposed on them.

Both in policy and in research, employability is often discussed in relation to chronological age. Studies mostly find negative relationships between age and employability (De Cuyper, Mauno, Kinnunen, \& Mäkikangas, 2011; Nauta, De Vroome, Cox, Korver, \& Kraan, 2005; Raemdonck, Tillema, Grip, Valcke, \& Segers, 2012; Rothwell \& Arnold, 2007; Van der Heijden, 2002; Van Vuuren, Caniels, \& Semeijn, 2011; Wittekind, Raeder, \& Grote, 2010) and related concepts, such as workability (Nielsen, 1999) and career opportunities (Van Veldhoven \& Dorenbosch, 2008). Despite these consistent findings it remains difficult to tell why exactly this relationship is negative. This is because chronological age is a proxy measure for many changes related to aging: physical and mental changes, ageism, effects of the period of time or the cohort (Hall, Mairesse, \& Turner, 2007). A second problem is that the older people get and the more experience they accumulate, the more heterogeneous they become (Carstensen, 2006). Consequently, the predictive value of chronological age diminishes. Additionally, it is questionable which recommendations should be given to human resource managers. After all, individuals' chronological age may not be altered. Despite these shortcomings, both practitioners and researchers use chronological age as an easy to measure proxy for the physical, cognitive, social, and emotional changes associated with human development (Pitt-Catsouphes, Matz-Costa, \& Besen, 2009).

\section{MOTIVATION TO STAY EMPLOYABLE: FUTURE TIME PERSPECTIVE AND GOAL ORIENTATION}

Froehlich, Beausaert, and Segers (2014) identify two motivational concepts related to age and competence development: future time perspective (Carstensen, 2006) and goal orientation (Elliot \& McGregor, 2001) that may explain the relationship between chronological age and employability. According to socioemotional selectivity theory (Carstensen, Isaacowitz, \& Charles, 1999), future time perspective concerns the available time individuals believe to have left in their future working life. This perspective affects the motivation to learn and perform (Raemdonck, 
Beausaert, Froehlich, Kochoian, \& Meurant, 2015). Zacher and Frese (2009, 2011) adjusted the concept to workplace settings and found two dimensions: perceived remaining opportunities and perceived remaining time at work.

While we are not aware of a study that has explicitly investigated the relationship between future time perspective and employability, we know from related literatures that an extensive future time perspective is associated with, for instance, improved work performance (Zacher, Heusner, Schmitz, Zwierzanska, \& Frese, 2010), increased persistence to study (Horstmanshof \& Zimitat, 2007), and better academic performance (De Volder \& Lens, 1982). Lang and Carstensen (2002) report that while individuals perceiving the future as limited prefer emotional goals and thus relatives and formal partners, individuals who have an expansive perception of the future prefer to interact with acquaintances and knowledgeable or controversial partners to fulfill their desire for growth. Accordingly, we hypothesize that perceived remaining opportunities and perceived remaining time at work relate positively to employability.

Hypothesis 1: The perceived remaining opportunities at work relate positively to occupational expertise, anticipation and optimization, and personal flexibility.

Hypothesis 2: The perceived remaining time at work relates positively to occupational expertise, anticipation and optimization, and personal flexibility.

Goal orientation research investigates "how individuals interpret and respond to achievement situations" (Brett \& VandeWalle, 1999, p. 864). Janssen and Prins (Janssen \& Prins, 2007) distinguish four dimensions, depending on how people define competence (against an absolute standard, own past performance, or others' performance) and the valence they ascribe to it (approaching success versus avoiding failure). People may aim to develop competences (mastery approach orientation), avoid deterioration and loss of competences (mastery avoid orientation), demonstrate competences to get favorable judgments (performance approach orientation), or avoid demonstration of lack of competences to eschew negative judgments (performance avoid orientation). 
We are not aware of empirical tests of the relationship between goal orientation and employability. However, competence is essential to the goal orientation concept (Elliot \& McGregor, 2001), and research does find effects of goal orientation on performance and competence development. Van Yperen, Elliot, and Anseel (2009) report that mastery avoid orientation leads to little performance improvement compared to the other three goal orientations. Schulz and Stamov-Roßnagel (2010) note a positive relationship between mastery orientation and a composite measure which includes, amongst others, self-reported assessments of efficiency improvements and contentedness with one's learning success. Payne, Youngcourt, and Beaubien (2007) find positive effects of a mastery orientation on both learning and performance outcomes and negative effects of performance avoid orientation in a meta-analysis across 141 empirical studies.

Goal orientation affects learning behavior - and it may subsequently also influence employability. Mastery approach orientation is associated with positive outcomes - for instance, increased help-seeking (Roussel, Elliot, \& Feltman, 2011), feedback-seeking (Van der Rijt, Van den Bossche, Van de Wiel, Segers, \& Gijselaers, 2012), information-seeking (Janssen \& Prins, 2007), or training performance and study effort (Fisher \& Ford, 1998). The other orientations produce more modest outcomes. In sum, mastery approach orientation is associated with positive effects regarding learning and performance, while the other goal orientations show no or negative effects. These studies point to the importance of goal orientation for employees' performance and learning. To date, this theory has received little attention in employability research. Since we assume that learning results in higher expertise and flexibility, we hypothesize positive relations of mastery and performance approach orientations and negative relations of mastery and performance avoid orientations with employability.

Hypothesis 3: Mastery and performance approach orientation relate positively

to occupational expertise, anticipation and optimization, and personal flexibility. 
Hypothesis 4: Mastery and performance avoid orientation relate negatively to

occupational expertise, anticipation and optimization, and personal flexibility.

Studies find that chronological age affects employees' goals: Older people are more oriented towards maintaining their status (Ebner, Freund, \& Baltes, 2006; Ogilvie, Rose, \& Heppen, 2010), strive less for earnings, productivity, or promotions (Zwick, 2011), and have a decrease in growth motives (Kooij, de Lange, Jansen, Kanfer, \& Dikkers, 2011). A similar relation with chronological age was found for perceived opportunities and perceived time: Both dimensions related negatively to chronological age in the studies of Zacher and Frese $(2009,2011)$. This finding is in line with previous research on future time perspective (e.g., De Lange, Bal, Van der Heijden, De Jong, \& Schaufeli, 2011; Lang \& Carstensen, 2002) and supports the theoretical claim that older people perceive their remaining time as more limited, as they are closer to retirement age and, more generally, life expectancy (Carstensen et al., 1999).

Because chronological age is negatively related to perceived remaining opportunities and time, and perceived remaining opportunities and time, in turn, relate positively to employability (see Figure 1), we expect that chronological age relates negatively and indirectly to employability. Similarly, we expect goal orientation to mediate the relationship between chronological age and employability.

Hypothesis 5: Future time perspective and goal orientation mediate the relation between chronological age and occupational expertise, anticipation and optimization, and personal flexibility. 


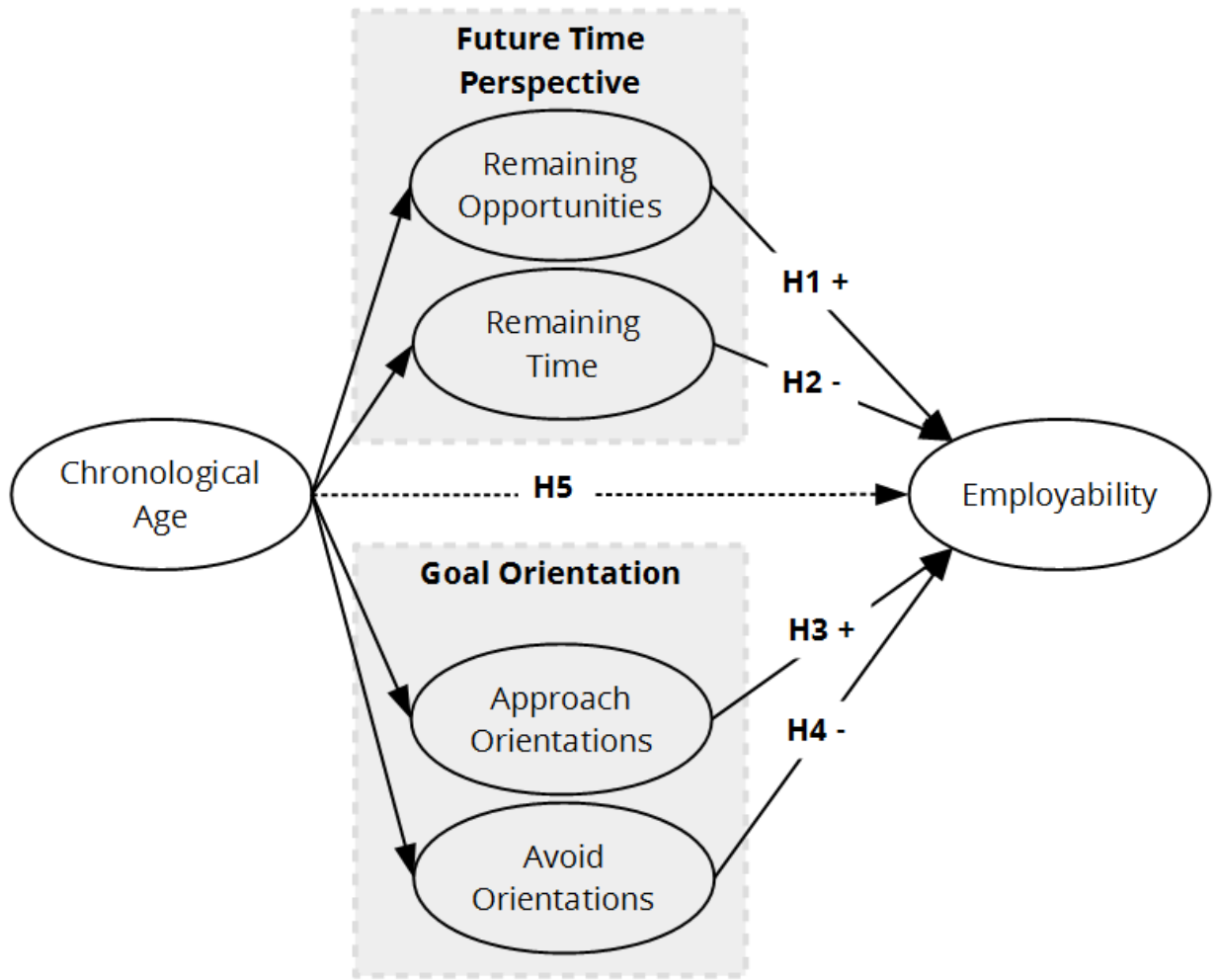

Figure 1: Research model of this chapter.

\section{MetHODS}

\section{Sample and procedure}

Three organizations participated in this research:

- a Dutch emergency services organization, in which the employees give first aid, manipulate (complex) devices, and do administrative work,

- an Austrian IT consultancy, in which employees usually work in close collaboration with their clients to implement and consult about complex solutions, and

- an Austrian consultancy that offers a wider array of services, including, for instance, consultations about international law and policy.

Consultancies are an interesting setting for this study due to the industry-specific demand for employability (Petersitzke \& Hristozova, 2006). 
Likewise, maintaining competences is important for providing critical emergency services. In total, we contacted 503 employees via e-mail. 321 questionnaires were returned, of which 282 (56\%) were complete and used for further analyses. Table 1 displays the sample characteristics.

Table 1: Characteristics of the sample.

\begin{tabular}{|c|c|c|c|c|}
\hline & $\begin{array}{c}\text { Public } \\
\text { organization }\end{array}$ & $\begin{array}{c}\text { IT } \\
\text { consultancy }\end{array}$ & $\begin{array}{l}\text { Emergency } \\
\text { services }\end{array}$ & Total \\
\hline Country & Austria & Austria & Netherlands & \\
\hline Sample Size & 90 & 77 & 115 & 282 \\
\hline Age Mean (SD) & $41.86(10.26)$ & $39.56(9.34)$ & $43.37(8.13)$ & 41.85 (9.28) \\
\hline $\begin{array}{l}\text { Years on Job } \\
\text { Mean (SD) }\end{array}$ & $10.84(8.47)$ & $7.02(6.51)$ & $9.78(6.70)$ & 9.37 (7.39) \\
\hline $\begin{array}{l}\text { \% Higher } \\
\text { Education }\end{array}$ & $51.10 \%$ & $61.00 \%$ & $47.80 \%$ & $52.48 \%$ \\
\hline$\%$ Female & $63.30 \%$ & $37.70 \%$ & $27.80 \%$ & $41.84 \%$ \\
\hline
\end{tabular}

\section{Measures}

We only used validated instruments for this research. Respondents answered on a five-point Likert-scale ( 1 = strongly disagree, $5=$ strongly agree).

We measured employability using three scales by Van der Heijde and Van der Heijden (2006): occupational expertise (Sample item: "I consider myself competent to engage in in-depth, specialist discussions in my job domain;" $a=0.92$ ), anticipation and optimization (Sample item: "I take responsibility for maintaining my labor market value;" $a=0.78$ ), and personal flexibility (Sample item: "I adapt to developments within my organization;" $a=0.73$ ). This model fits our data $\left(C F I=0.99, \chi^{2} / d f=1.61\right.$, SRMR $=0.03$, RMSEA $=0.05$ ).

We assessed future time perspective using Lang and Carstensen's (2002) ten-item scale. Like in Kooij et al.'s (2014) study, the three reversely coded items ("I have the sense that time in my working life is running out," "As I get older, I begin to experience that time in my working life is limited," and "There are only limited possibilities in my occupational future.") reduced 
the instrument's reliability. Thus, we removed them from further analyses. In agreement with Zacher and Frese (2009), we find the best model fit for a two-factor solution $\left(\mathrm{CFI}=0.99, \chi^{2} / \mathrm{df}=1.50\right.$, SRMR $=0.02$, RMSEA $\left.=0.04\right)$. The reliabilities for perceived remaining opportunities (Sample item: Many opportunities await me in my occupational future;" $\alpha=0.89$ ) and perceived remaining time (Sample item: "Most of my occupational life lies ahead of me."; $a=0.70$ ) were acceptable.

We adapted Elliot and McGregor's (2001) twelve-item Achievement Goal Questionnaire to a workplace setting to gauge goal orientation. Initial confirmatory factor analyses showed no satisfactory model fit (CFI $=0.86$, $\chi^{2} / \mathrm{df}=3.90, \mathrm{SRMR}=0.08, \mathrm{RMSEA}=0.10$ ); the performance avoid subscale had low reliability $(a=0.47)$. We re-ran the analyses without this subscale to achieve both a good fit of the model (CFI $=0.96, \chi^{2} / \mathrm{df}=2.45$, SRMR $=0.06$, RMSEA $=0.07$ ) and acceptable reliabilities for mastery approach orientation (Sample item: "I want to learn as much as possible at work."; $a=0.70$ ), performance approach orientation (Sample item: "It is important for me to do better than other employees."; $a=0.86$ ), and mastery avoid orientation (Sample item: "I am often concerned that I may not learn all that there is to learn at work."; $a=0.69$ ).

We asked for the chronological age of the respondents in an open question. Furthermore, we controlled for the highest level of education (required schooling, secondary, or tertiary level) and the number of years of experience on the current job (open question). Two dummy variables represented the respondents' affiliation to one of the organizations.

\section{Analyses}

We used structural equation modeling with Mplus 7.11 (Muthén \& Muthén, 2012) to test all hypotheses. We assessed model fit using root mean square error of approximation (RMSEA, acceptable if $\leq 0.08$; Browne and Cudeck, 1993), comparative fit index (CFI, acceptable if $\geq 0.90)$, and standardized root mean squared residuals (SRMR, acceptable if $\leq 0.08)(\mathrm{Hu}$ \& Bentler, 1999). We randomly assigned each observed item of the employability scales to one of three parcels per dimension to achieve a better relation between the number of parameters and the given sample size (Little, Cunningham, Shahar, \& Widaman, 2002). 


\section{RESULTS}

\section{Correlation analysis}

Table 2 indicates strong correlations among the dimensions of employability $(r>0.45, p<0.01)$ and a strong negative correlation of remaining opportunities and time with chronological age $(r=-0.50, p<0.01$ and $r=-0.68, p<0.01$, respectively). All hypothesized independent variables correlate significantly with at least one dimension of employability. 


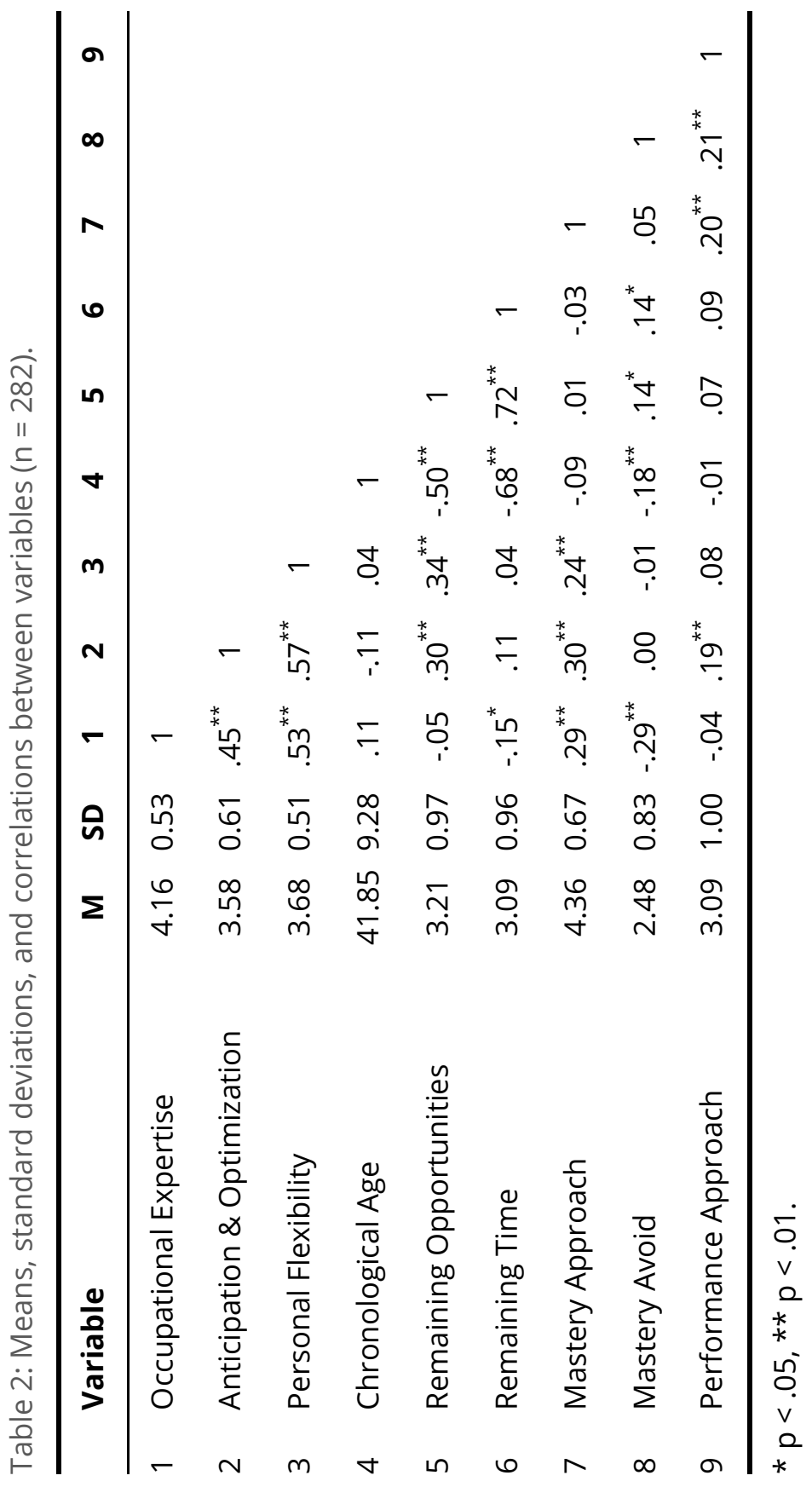




\section{Model fit}

The model fits the data $\left(C F I=0.90, \chi^{2} / d f=2.25\right.$, SRMR $=0.06$, RMSEA $=0.07)$ and explains large parts of the variance in the employability scales $\left(R^{2}=0.35\right.$ to 0.57$)$. Since we analyze self-reported, cross-sectional data, we statistically control for common method variance (Podsakoff, Mackenzie, Lee, \& Podsakoff, 2003). We confirm that a single general factor model does not fit the data well $\left(C F I=0.27, \chi^{2} / d f=9.03\right.$, SRMR $=0.18$, RMSEA $=0.17$ ). Also, we controlled for effects of a single latent unmeasured latent method factor by adding a first-order factor with all measures as indicators to the model. This factor had no significant effects. Both tests do not indicate common method variance. In sum, we are confident that the impact of potential common method variance is limited, given that the self-appraised conceptualization of employability used in this study can only be evaluated via self-reports and that we did not find any indications of such bias in the statistical tests presented above (Conway \& Lance, 2010).

\section{Hypotheses testing}

Table 3 shows a positive relation between remaining opportunities and anticipation and optimization $(\beta=0.89, p<0.01)$ and personal flexibility $(\beta=1.28, p<0.01)$. This gives partial support to Hypothesis 1 . We found no support for Hypothesis 2, which expected a significant relationship also between remaining time and the dimensions of employability. Mastery approach orientation relates positively to all dimensions of employability ( $\beta$ $=0.30$ to $0.42, p<0.01$ ); mastery avoid orientation relates negatively to occupational expertise $(\beta=-0.41, p<0.01$ ) and anticipation and optimization $(\beta=-0.21, p<0.01)$. Performance approach orientation has a positive relationship with anticipation and optimization $(\beta=0.14, p<0.05)$. This partially supports Hypotheses 3 and 4. Additionally, we found differences between the samples for occupational expertise $(\beta=0.21, p<0.05)$ 
Table 3: Standardized coefficients of the model variables and control variables on employability.

\begin{tabular}{lccc}
\hline & $\begin{array}{c}\text { Occupational } \\
\text { Expertise }\end{array}$ & $\begin{array}{c}\text { Anticipat. \& } \\
\text { Optimization }\end{array}$ & $\begin{array}{c}\text { Personal } \\
\text { Flexibility }\end{array}$ \\
\hline Remaining Opportunities & .17 & $.89^{\star \star}$ & $1.28^{\star \star}$ \\
Remaining Time & -.27 & -1.06 & -1.44 \\
Mastery Approach & $.30^{\star \star}$ & $.42^{\star \star}$ & $.36^{\star \star}$ \\
Mastery Avoid & $-.41^{\star \star}$ & $-.21^{\star \star}$ & -.13 \\
Performance Approach & .03 & $.14^{\star}$ & .00 \\
Chronological Age & -.10 & -.54 & -.52 \\
Educational Level & .06 & .14 & .12 \\
Years on the Job & .09 & -.01 & -.01 \\
Organization 1 & $.21^{\star}$ & -.03 & -.11 \\
Organization 2 & .14 & -.07 & -.05 \\
\hline * p <.05, ** $\mathrm{p}<.01$. & & &
\end{tabular}

We found two significant indirect relationships between age and employability. Specifically, remaining opportunities negatively mediates the relationship between chronological age and anticipation and optimization ( $\beta$ $=-0.44, p<0.05)$ and personal flexibility $(\beta=-0.64, p<0.01)$. This gives weak, partial support to Hypothesis 5.

\section{Post-hoc analysis}

The model shows no significant effect of chronological age on employability. This contradicts previous studies (e.g., De Cuyper et al., 2011; Raemdonck et al., 2012; Van Vuuren et al., 2011). In a post-hoc analysis, we tested the model without perceived remaining opportunities, perceived remaining time, and tenure, all of which correlated strongly with chronological age $(|r| \geq .50)$. This model $\left(\mathrm{CFI}=0.89, \chi^{2} / \mathrm{df}=2.73, \mathrm{SRMR}=\right.$ 0.06, RMSEA $=0.08$ ) shows a weak negative relationship between chronological age and anticipation and optimization $(\beta=-0.11, p<0.10)$. Hence, including perceived remaining opportunities, perceived remaining time, and tenure in the model weakens the relationship between age and 
employability. This indicates a mediation effect (Mackinnon, Krull, \& Lockwood, 2000).

\section{Discussion}

We set out to investigate the relationship between age and employability. We aimed to identify motivational mediators between chronological age and employability that individuals and organizations may act upon. Five major themes emerged from the analyses. First, the employees' perception of their remaining opportunities and time was strongly and negatively related to their age. This agrees with previous studies (e.g., Lang \& Carstensen, 2002). While we did not find employability to relate to age or remaining time, we found a positive relationship with remaining opportunities. This is in line with Zacher and Frese (2009), who argue that the perception of remaining opportunities is more strongly influenced by personal and organizational characteristics than remaining time. This is because the latter is more narrowly constrained by, for example, rather rigidly stipulated ages for retirement. Additionally, since we have found these positive effects in a sample of well educated employees, it agrees with Wittekind et al. (2010), who theorized that highly qualified people benefit from being aware of the opportunities around them more than their lower qualified colleagues. This is because higher qualifications improve the chance to put the potential opportunities into effect. Organizations may strive to extend their employees' future time perspective to enhance staff's employability. This includes, for instance, clarifying the instrumentality of any learning activity for future success beforehand (Simons, Vansteenkiste, Lens, \& Lacante, 2004), communicating the role of work-related learning and personal goals (Phalet, Andriessen, \& Lens, 2004), or facilitating long-term planning and the use of personal development plans (Beausaert, Segers, Van der Rijt, \& Gijselaers, 2011; Gellert, Ziegelmann, Lippke, \& Schwarzer, 2012).

Second, we found relationships between goal orientation and employability. As expected, mastery and performance approach orientations relate positively to employability, while mastery avoid orientation relates negatively to employability. This is in line with previous research (Schulz \& Stamov-Roßnagel, 2010; Van Yperen et al., 2009). This 
finding suggests that, for instance, attempting to avoid making errors may be counterproductive for sustaining one's employability. Instead, managers may aim to stimulate a mastery approach orientation among employees. This can be achieved by, for example, offering goal orientation training (Noordzij, Van Hooft, Van Mierlo, Van Dam, \& Born, 2013), evaluating employees on their progress and improvement (Ames, 1992), or by creating more tolerance towards errors and accepting them as a part of learning (Van Yperen \& Orehek, 2013).

Third, we found indirect relationships via perceived remaining opportunities. This extends previous research that finds relations between chronological age and employability (e.g., Raemdonck et al., 2012; Rothwell \& Arnold, 2007; Van Vuuren et al., 2011), but that did not further explain the mechanism behind it. We did not find a significant relationship between age and employability in the main model, but the post-hoc analysis gave additional evidence for a mediation effect. This also has important implications for designing the workplace of older employees. Instead of focusing on a variable that cannot be influenced - chronological age -, our research hints at the potential to target employees' motivation. The evidence questions the predominant use of chronological age as decisive criterion in organizational and national policies. In the recent public debate about retirement age and other workplace-related discussions, chronological age plays a much more prominent role than the findings presented here suggest it should. While data about chronological age is often cheaply and readily accessible, the findings suggest to step back from this practice and to look at other, more predictive factors, too (cf. Zacher et al., 2010). Furthermore, organizations may educate against ageism, for instance by fostering high-quality intergenerational contact (Iweins, Desmette, Yzerbyt, \& Stinglhamber, 2013) or offering age awareness trainings (Armstrong-Stassen \& Templer, 2005), and consider their human resource management approach towards older employees (Kooij, Jansen, Dikkers, \& De Lange, 2014; Kooij et al., 2013).

Fourth, the results indicate differences of occupational expertise between the participating organizations. This is in line with the notion that older employees' employability depends on both individual and institutional factors (Billett, 2011; Dymock, Billett, Klieve, Johnson, \& Martin, 2012). We 
included three organizations that are located in different countries and sectors. This allows us to make statements that are more generalizable than research conducted in one homogeneous sample only. Unfortunately, our level of analysis does not allow us to work out what factors exactly make the difference. For instance, it is probable that the tasks in the Austrian chamber, which mainly concern the consolidation of diverging interests among different stakeholders in the economy, are far less structured and more complex than the tasks needed to provide emergency services, where a standardized set of methods is applied to provide fast and reliable help. They also differ from the competences required to sell and implement IT solutions, as needed in the third organization. This might imply that engagement in complex tasks impacts employability. Further research is required to address this topic of contextual differences in adequate depth.

Fifth, the results are different for each dimension of employability. While this finding is in line with previous research (e.g., De Vos, De Hauw, \& Van der Heijden, 2011; Froehlich, Beausaert, Segers, et al., 2014), we do not sufficiently understand these differences. Focusing on their future career opportunities makes employees more attentive towards environmental changes and more flexible to react to them when they arise. However, we did not find a significant relationship between remaining opportunities and occupational expertise. This might be because the perception of remaining opportunities is future-oriented, while expertise is a result of past learning and development. Thus, the lack of relationship may be explained by the respondent's extensive experience on the current job of on average over ten years and their already high level of occupational expertise (cf. Table 1). In conclusion, further research may explore the relationships between the dimensions of employability in detail. For instance, this may include a qualitative investigation, which is able to research the specificities of the model in greater detail.

In conclusion, investigating the relationship between age and employability and finding indirect age effects lets us understand why older employees are often perceived to be less employable. After all, age does have an influence. However, it is not the age per se - an unchangeable factor - that matters. It is the motivation. This empowers individuals to take control of their own employability. 


\section{REFERENCES}

Ames, C. (1992). Classrooms: Goals, Structures, and Student Motivation. Journal of Eduactional Psychology, 84(3), 261-271.

Armstrong-Stassen, M., \& Templer, A. (2005). Adapting Training for Older Employees: The Canadian Response to an Aging Workforce. Journal of Management Development, 24(1), 57-67. doi:10.1108/02621710510572353

Bal, P. M., Kooij, D. T. A. M., \& Rousseau, D. M. (2015). Introduction to aging workers and the employee-employer relationship. In P. M. Bal, D. T. A. M. Kooij, \& D. M. Rousseau (Eds.), Aging workers and the employeeemployer relationship (pp. 1-9). Dordrecht: Springer.

Beausaert, S. A. J., Segers, M. S. R., Van der Rijt, J., \& Gijselaers, W. H. (2011). The Use of Personal Development Plans (PDPs) in the Workplace: A Literature Review. In P. Van den Bossche, W. H. Gijselaers, \& R. G. Milter (Eds.), Building Learning Experiences in a Changing World (Vol. 3, pp. 235265). Dordrecht: Springer Netherlands. doi:10.1007/978-94-007-0802-0

Billett, S. (2011). Promoting Lifelong Employability for Workforce Aged Over 45: Singaporean Workers' Perspectives. International Journal of Continuing Education and Lifelong Learning, 3(2), 57-73.

Brett, J. F., \& VandeWalle, D. (1999). Goal orientation and goal content as predictors of performance in a training program. Journal of Applied Psychology, 84(6), 863-873. doi:10.1037//0021-9010.84.6.863

Browne, M. W., \& Cudeck, R. (1993). Alternative Ways of Assessing Model Fit. In K. A. Bollen \& J. S. Long (Eds.), Testing structural equation models (pp. 136-162). Newbury Park, CA: Sage Publications.

Carstensen, L. L. (2006). The Influence of a Sense of Time on Human Development. Science, 312(5782), 1913-1915. doi:10.1126/science. 1127488

Carstensen, L. L., Isaacowitz, D. M., \& Charles, S. T. (1999). Taking Time Seriously: A Theory of Socioemotional Selectivity. American Psychologist, 54(3), 165-181. doi:10.1037/0003-066X.54.3.165

Conway, J. M., \& Lance, C. E. (2010). What Reviewers Should Expect from Authors Regarding Common Method Bias in Organizational Research. 
Journal of Business and Psychology, 25(3), 325-334. doi:10.1007/s10869010-9181-6

De Cuyper, N., Mauno, S., Kinnunen, U., \& Mäkikangas, A. (2011). The role of job resources in the relation between perceived employability and turnover intention: A prospective two-sample study. Journal of Vocational Behavior, 78(2), 253-263. doi:10.1016/j.jvb.2010.09.008

De Lange, A. H., Bal, P. M., Van der Heijden, B. I. J. M., De Jong, N., \& Schaufeli, W. B. (2011). When I'm 64: Psychological Contract Breach, Work Motivation and the Moderating Roles of Future Time Perspective and Regulatory Focus. Work \& Stress, 25(4), 338-354. doi:10.1080/02678373.2011.632610

De Volder, M. L., \& Lens, W. (1982). Academic Achievement and Future Time Perspective as a Cognitive-Motivational Concept. Journal of Personality and Social Psychology, 42(3), 566-571. doi:10.1037//0022-3514.42.3.566

De Vos, A., De Hauw, S., \& Van der Heijden, B. I. J. M. (2011). Competency development and career success: The mediating role of employability. Journal of Vocational Behavior, 79(2), 438-447. doi:10.1016/j.jvb.2011.05.010

Dries, N., Forrier, A., De Vos, A., \& Pepermans, R. (2014). Self-perceived employability, organization-rated potential, and the psychological contract. Journal of Managerial Psychology, 29(5), 565-581. doi:10.1108/JMP-04-2013-0109

Dymock, D., Billett, S., Klieve, H., Johnson, C., \& Martin, G. (2012). Mature age "white collar" workers' training and employability. International Journal of Lifelong Education, 31(2), 171-186. doi:10.1080/02601370.2012.663807

Ebner, N. C., Freund, A. M., \& Baltes, P. B. (2006). Developmental changes in personal goal orientation from young to late adulthood: from striving for gains to maintenance and prevention of losses. Psychology and Aging, 21(4), 664-78. doi:10.1037/0882-7974.21.4.664

Elliot, A. J., \& McGregor, H. A. (2001). A 2x2 Achievement Goal Framework. Journal of Personality and Social Psychology, 80(3), 501-519. 
Fisher, S. L., \& Ford, J. K. (1998). Differential Effects of Learner Effort and Goal Orientation on Two Learning Outcomes. Personnel Psychology, 51(2), 397-420. doi:10.1111/j.1744-6570.1998.tb00731.x

Froehlich, D. E., Beausaert, S. A. J., \& Segers, M. S. R. (2014). Age, employability and the role of learning activities and their motivational antecedents: a conceptual model. International Journal of Human Resource Management, 1-15. doi:10.1080/09585192.2014.971846

Froehlich, D. E., Beausaert, S. A. J., Segers, M. S. R., \& Gerken, M. (2014). Learning to Stay Employable. Career Development International, 19(5), 508-525. doi:10.1108/CDI-11-2013-0139

Fugate, M., \& Kinicki, A. J. (2008). A dispositional approach to employability: Development of a measure and test of implications for employee reactions to organizational change. Journal of Occupational and $\begin{array}{lll}\text { Organizational } & \text { 81(3), 503-527. }\end{array}$ doi:10.1348/096317907X241579

Gegenfurtner, A., \& Vauras, M. (2012). Age-related differences in the relation between motivation to learn and transfer of training in adult continuing education. Contemporary Educational Psychology, 37(1), 3346. doi:10.1016/j.cedpsych.2011.09.003

Gellert, P., Ziegelmann, J. P., Lippke, S., \& Schwarzer, R. (2012). Future time perspective and health behaviors: temporal framing of self-regulatory processes in physical exercise and dietary behaviors. Annals of Behavioral Medicine, 43(2), 208-18. doi:10.1007/s12160-011-9312-y

Hall, B. H., Mairesse, J., \& Turner, L. (2007). Identifying age, cohort, and period effects in scientific research productivity: discussion and illustration using simulated and actual data on french physicists. Economics of Innovation and New Technology, 16(2), 37-41.

Horstmanshof, L., \& Zimitat, C. (2007). Future time orientation predicts academic engagement among first-year university students. British Journal of Educational Psychology, 77(3), 703-718. doi:10.1348/000709906X160778

Hu, L., \& Bentler, P. M. (1999). Cutoff criteria for fit indexes in covariance structure analysis: Conventional criteria versus new alternatives. Structural Equation Modeling, 6(1), 1-55. 
Iweins, C., Desmette, D., Yzerbyt, V., \& Stinglhamber, F. (2013). Ageism at work: The impact of intergenerational contact and organizational multiage perspective. European Journal of Work and Organizational Psychology, 22(3), 331-346. doi:10.1080/1359432X.2012.748656

Janssen, O., \& Prins, J. (2007). Goal orientations and the seeking of different types of feedback information. Journal of Occupational and Organizational Psychology, 80, 235-249. doi:10.1348/096317906X103410

Kooij, D. T. A. M., Bal, P. M., \& Kanfer, R. (2014). Future time perspective and promotion focus as determinants of intraindividual change in work motivation. Psychology and Aging, 29(2), 319-328.

Kooij, D. T. A. M., de Lange, A. H., Jansen, P. G. W., \& Dikkers, J. S. E. (2008). Older workers' motivation to continue to work: five meanings of age: A conceptual review. Journal of Managerial Psychology, 23(4), 364-394. doi:10.1108/02683940810869015

Kooij, D. T. A. M., de Lange, A. H., Jansen, P. G. W., Kanfer, R., \& Dikkers, J. S. E. (2011). Age and Work-related Motives: Results of a Meta-analysis. Journal of Organizational Behavior, 32(1), 197-225. doi:10.1002/job

Kooij, D. T. A. M., Guest, D. E., Clinton, M., Knight, T., Jansen, P. G. W., \& Dikkers, J. S. E. (2013). How the impact of HR practices on employee well-being and performance changes with age. Human Resource Management Journal, 23(1), 18-35. doi:10.1111/1748-8583.12000

Kooij, D. T. A. M., Jansen, P. G. W., Dikkers, J. S. E., \& De Lange, A. H. (2014). Managing aging workers: a mixed methods study on bundles of HR practices for aging workers. International Journal of Human Resource Management, 1-21. doi:10.1080/09585192.2013.872169

Lang, F. R., \& Carstensen, L. L. (2002). Time counts: Future time perspective, goals, and social relationships. Psychology and Aging, 17(1), 125-139. doi:10.1037//0882-7974.17.1.125

Little, T. D., Cunningham, W. A., Shahar, G., \& Widaman, K. F. (2002). To Parcel or Not to Parcel: Exploring the Question, Weighing the Merits. Structural Equation Modeling, 9(2), 151-173. doi:10.1207/S15328007SEM0902_1 
Mackinnon, D. P., Krull, J. L., \& Lockwood, C. M. (2000). Equivalence of the Mediation, Confounding and Suppression Effect. Prevention Science, 1(4), 173.

Muthén, L. K., \& Muthén, B. O. (2012). Mplus User's Guide. Los Angeles, CA: Muthén \& Muthén.

Nauta, A., De Vroome, E., Cox, E., Korver, T., \& Kraan, K. (2005). De invloed van functietype op het verband tussen leeftijd en inzetbaarheid [The influence of function type on the relationship between age and employability]. Gedrag \& Organisatie, 18(6), 326-337.

Nielsen, J. (1999). Employability and Workability among Danish Employees. Experimental Aging Research, 25(4), 393-397.

Noordzij, G., Van Hooft, E. A. J., Van Mierlo, H., Van Dam, A., \& Born, M. P. (2013). The Effects of a Learning-Goal Orientation Training on SelfRegulation: A Field Experiment Among Unemployed Job Seekers. Personnel Psychology, 66(3), 723-755. doi:10.1111/peps.12011

Ogilvie, D. M., Rose, K. M., \& Heppen, J. B. (2010). A Comparison of Personal Project Motives in Three Age Groups. Basic and Applied Social Psychology, 23(3), 207-215.

Payne, S. C., Youngcourt, S. S., \& Beaubien, J. M. (2007). A meta-analytic examination of the goal orientation nomological net. Journal of Applied Psychology, 92(1), 128-50. doi:10.1037/0021-9010.92.1.128

Petersitzke, M., \& Hristozova, E. (2006). Managing Employability in the German Consultancy Industry. In M. E. Domsch \& E. Hristozova (Eds.), Human Resource Management in Consulting Firms (pp. 191-211). Berlin: Springer.

Phalet, K., Andriessen, I., \& Lens, W. (2004). How Future Goals Enhance Motivation and Learning in Multicultural Classrooms. Educational Psychology Review, 16(1), 59-89. doi:10.1023/B:EDPR.0000012345.71645.d4

Pitt-Catsouphes, M., Matz-Costa, C., \& Besen, E. (2009). Workplace Flexibility: Findings from the Age \& Generations Study. Issue Brief No. 19. Chestnut Hill, MA: Sloan Center on Aging \& Work at Boston College. 
Podsakoff, P. M., Mackenzie, S. B., Lee, J.-Y., \& Podsakoff, N. P. (2003). Common method biases in behavioral research: a critical review of the literature and recommended remedies. Journal of Applied Psychology, 88(5), 879-903. doi:10.1037/0021-9010.88.5.879

Raemdonck, I., Beausaert, S. A. J., Froehlich, D. E., Kochoian, N., \& Meurant, C. (2015). Age related changes in learning and employability. In D. Rosseau, D. T. A. M. Kooij, \& P. M. Bal (Eds.), Aging Workers and the Employee-Employer Relationship (pp. 163-184).

Raemdonck, I., Tillema, H. H., Grip, A., Valcke, M., \& Segers, M. S. R. (2012). Does Self-directedness in Learning and Careers Predict the Employability of Low-Qualified Employees? Vocations and Learning, 5(2), 137-151. doi:10.1007/s12186-011-9072-7

Rothwell, A., \& Arnold, J. (2007). Self-perceived employability: Development and validation of a scale. Personnel Review, 36(1), 23-41. doi:10.1108/00483480710716704

Roussel, P., Elliot, A. J., \& Feltman, R. (2011). The influence of achievement goals and social goals on help-seeking from peers in an academic context. Learning and Instruction, 21(3), 394-402. doi:10.1016/j.learninstruc.2010.05.003

Schulz, M., \& Stamov-Roßnagel, C. (2010). Informal workplace learning: An exploration of age differences in learning competence. Learning and Instruction, 20(5), 383-399. doi:10.1016/j.learninstruc.2009.03.003

Simons, J., Vansteenkiste, M., Lens, W., \& Lacante, M. (2004). Placing Motivation and Future Time Perspective Theory in a Temporal Perspective. Educational Psychology Review, 16(2), 121-139. doi:10.1023/B:EDPR.0000026609.94841.2f

Tolentino, L. R., Garcia, P. R. J. M., Lu, V. N., Restubog, S. L. D., Bordia, P., \& Plewa, C. (2014). Career adaptation: The relation of adaptability to goal orientation, proactive personality, and career optimism. Journal of Vocational Behavior, 84(1), 39-48. doi:10.1016/j.jvb.2013.11.004

Van der Heijde, C. M., \& Van der Heijden, B. I. J. M. (2006). A competencebased and multidimensional operationalization and measurement of employability. Human Resource Management, 45(3), 449-476. doi:10.1002/hrm.20119 
Van der Heijden, B. I. J. M. (2002). Prerequisites to guarantee life-long employability. Personnel Review, 31(1), 44-61. doi:10.1108/00483480210412418

Van der Rijt, J., Van den Bossche, P., Van de Wiel, M. W. J., Segers, M. S. R., \& Gijselaers, W. H. (2012). The role of individual and organizational characteristics in feedback-seeking behaviour in the initial career stage. Human Resource Development International, 15(3), 283-301. doi:10.1080/13678868.2012.689216

Van Veldhoven, M. J. P. M., \& Dorenbosch, L. (2008). Age, Proactivity and Career Development. Career Development International, 13(2), 112-131. doi:10.1108/13620430810860530

Van Vuuren, T., Caniels, M. C. J., \& Semeijn, J. H. (2011). Duurzame inzetbaarheid en een leven lang leren [Sustainable employability and lifelong learning]. Gedrag \& Organisatie, 24(4), 356-373.

Van Yperen, N. W., Elliot, A. J., \& Anseel, F. (2009). The influence of masteryavoidance goals on performance improvement. European Journal of Social Psychology, 39(6), 932-943. doi:10.1002/ejsp.590

Van Yperen, N. W., \& Orehek, E. (2013). Achievement goals in the workplace: Conceptualization, prevalence, profiles, and outcomes. Journal of Economic Psychology, 38, 71-79. doi:10.1016/j.joep.2012.08.013

Vanhercke, D., De Cuyper, N., Peeters, E., \& De Witte, H. (2014). Defining perceived employability: a psychological approach. Personnel Review, 43(4), 592-605. doi:10.1108/PR-07-2012-0110

Wittekind, A., Raeder, S., \& Grote, G. (2010). A Longitudinal Study of Determinants of Perceived Employability. Journal of Organizational Behavior, 31(4), 566-586. doi:10.1002/job.646

Zacher, H., \& Frese, M. (2009). Remaining time and opportunities at work: Relationships between age, work characteristics, and occupational future time perspective. Psychology and Aging, 24(2), 487-493. doi:10.1037/a0015425

Zacher, H., \& Frese, M. (2011). Maintaining a focus on opportunities at work: The interplay between age, job complexity, and the use of selection, 
optimization, and compensation strategies. Journal of Organizational Behavior, 32(1), 291-318. doi:10.1002/job.683

Zacher, H., Heusner, S., Schmitz, M., Zwierzanska, M. M., \& Frese, M. (2010). Focus on opportunities as a mediator of the relationships between age, job complexity, and work performance. Journal of Vocational Behavior, 76(3), 374-386. doi:10.1016/j.jvb.2009.09.001

Zwick, T. (2011). Why Training Older Employees is Less Effective (No. 11-046). Mannheim: Centre for European Economic Research. 
118 | Motivated to Stay Employable 


\section{CHAPTER 5}

\section{Great Expectations: The Relationship between Future Time Perspective, Informal Learning from Others, and Employability*}

* This chapter is based on: Froehlich, D. E., Beausaert, S. A. J., \& Segers, M. S. R. (In press). Great Expectations: The relationship between Future Time Perspective, Learning from Others, and Employability. Vocations and Learning. doi:10.1007/s12186-015-9131-6

Froehlich, D. E., Beausaert, S. A. J., \& Segers, M. S. R. (2014). Age, Attitudes, Activities: How future time perspective and learning activities shape older employees' employability. Paper presented at the EARLI SIG 14. Oslo. 


\section{ABstract}

Employees in countries with advanced industrial economies need to continuously develop their competences to sustain their employability - that is, to have a set of competences that enables them to maintain or find an adequate job. But how should efforts to enhance employability progress in the context of the demographic shift? Previous research suggests that employees' perspective about their future working life may influence their motivation to engage in learning activities. The study reported and discussed here investigates how employees' perceptions of the future as a time of opportunities and limitations affects their engagement in informal learning from others and, in turn, their employability. We tested our model empirically in two Austrian consultancies $(n=167)$. We find that focus on opportunities in the future explains engagement in informal learning from others and, subsequently, differences in employability. The informants' perspectives about the future may be a helpful alternative to the measurement of chronological age, which is problematic from a conceptual point of view. 


\section{INTRODUCTION}

The populations of most countries with advanced industrial economies are aging (OECD, 2012). Policymakers react to this situation by encouraging longer working lives (e.g., later retirement; European Commission, 2012) to maintain the viability of their social welfare systems (Walker \& Maltby, 2012) and to avert the loss of workplace skills and knowledge caused by the large number of workers retiring in the upcoming years (Midtsundstad \& Bogen, 2014). This situation is exacerbated by companies' aging workforces. For example, the German car manufacturer BMW estimates that the number of workers older than 50 doubles between 2010 and 2020 (Anderson, 2013). At the same time, increasing global competition and accelerating rates of innovation make work requirements more and more dynamic. But how do these two trends - the demographic shift and the increasingly fast-paced business world - relate to each other? After all, older employees' ability to adapt to such a dynamic environment is often doubted by employers, although the evidence is ambiguous (Finkelstein, King, \& Voyles, 2015). In a similar vein, research indicates that older employees are disproportionally more often subject to layoffs during restructuring measures (Kim \& Mo, 2014) and have greater difficulty to find a job should they lose their current employment (Ahmed, Andersson, \& Hammarstedt, 2012; Albert, Escot, \& Fernández-Cornejo, 2011). Put differently, older people's competence to fulfill, acquire, or create work for themselves - their employability (Van der Heijde \& Van der Heijden, 2006) is questioned, albeit often based on societal sentiments rather than actual evidence (cf. Meyers, Billett, \& Kelly, 2010).

But how should efforts to enhance employability progress in the context of an aging workforce? Research suggests that learning activities such as working on developmental tasks, networking, or attending trainings are adequate means of improving individuals' employability (Froehlich, Beausaert, \& Segers, 2014; Van der Heijden, Boon, Van der Klink, \& Meijs, 2009; Van der Klink, Van der Heijden, Boon, \& Williams van Rooij, 2014; Van Emmerik, Schreurs, De Cuyper, Jawahar, \& Peeters, 2012). Previous studies have found that informal learning from others - in contrast to the learning opportunities offered in trainings - is especially important for older employees (Billett, 2011; Froehlich, Beausaert, Segers, \& Gerken, 2014). The 
hypothesized reason for this is that informal learning from others is less dependent on employers' resources, which are often not accessible for older employees. As mentioned by Billett and Van Woerkom (2008), younger employees are often privileged in terms of receiving support and opportunities for learning in the workplace. Older employees, therefore, need to develop their own ways of learning and building their competences. In sum, several studies find significant relationships between learning activities and employability in the context of an aging workforce. But they do not explain why some older employees keep developing their employability and others do not.

So, this leads to the question about which personal factors play a role when it comes to undertaking learning activities for enhancing employees' employability in the context of the demographic shift. Previous research suggests that future time perspective is an important concept when studying older people's motivation to learn (Bal \& Jansen, 2015; Gegenfurtner \& Vauras, 2012; Kooij, Bal, \& Kanfer, 2014). Future time perspective refers to people's perceptions of how many opportunities (i.e., opportunity focus) and limitations (i.e., limitation focus) are ahead of them in their (working) life (Cate \& John, 2007). This perspective has been linked to, for instance, a focus on promotions (Kooij et al., 2014), work motivation (De Lange, Bal, Van der Heijden, De Jong, \& Schaufeli, 2011), or work performance (Zacher, Heusner, Schmitz, Zwierzanska, \& Frese, 2010). The relationship between individuals' future time perspective and their employability, however, has not yet been empirically researched (Raemdonck, Beausaert, Froehlich, Kochoian, \& Meurant, 2015). Therefore, the aim here is to investigate how employees' future time perspectives are linked to their employability through informal learning from others. We extend previous research that has connected learning activities to employability (Froehlich, Beausaert, Segers, et al., 2014; Van der Heijden et al., 2009) by adding future time perspective as an antecedent for explaining their learning. This additional information may be essential for understanding why some employees lose in employability, while others are able to maintain or even extend their competences. 


\section{COMPETENCE-BASED EMPLOYABILITY}

Being employable comprises having a set of competences that enables people to fulfill, acquire, or create work for themselves (Van der Heijde \& Van der Heijden, 2006). The advantage of this competence-based definition is that in today's times of fluctuating labor market demands, such competences provide a relatively stable basis for that employability. This, however, does not mean that employability is a static concept: Employability may increase or decrease dynamically, as employees can develop or lose their workplace competences (Sanders \& De Grip, 2004). Van der Heijde and Van der Heijden (2006) privileges occupational expertise as an important prerequisite for employability. Additionally, employability requires more generic social and adaptive competences (Rodriguez, Patel, Bright, Gregory, \& Gowing, 2002; Wright \& Snell, 1998). Employees need to proactively screen the environment and prepare themselves for potential changes in job and career requirements and conditions (i.e., anticipation and optimization) and adapt to them (i.e., personal flexibility) (Fugate, Kinicki, \& Ashforth, 2004). Furthermore, identification with the organization's goals and the ability to work together with others (i.e., corporate sense) are beneficial (Podsakoff, Ahearne, \& Mackenzie, 1997). Last, Van der Heijde and Van der Heijden (2006) name balance as a key competence. This comprises employees' ability to weigh employer's interests against theirs (e.g., balance of working and learning). In sum, these five competences should allow employees to fulfill, acquire, or create work for themselves.

Employees, however, act based on their own perceptions, not just on the bases of some prescriptions of how they should act. Therefore, it is necessary to account for employees' subjective ratings of their competences in this study. This view is consistent with earlier research (Fugate et al., 2004; Van Emmerik et al., 2012). Kinnunen et al. (2011), for instance, derive the importance of self-perceived employability from Lazarus and Folkman's (1984) transactional stress theory. These theorists argue that employees who perceive themselves as employable feel less threatened by the environment, experience less strain (Berntson \& Marklund, 2007), and engage more in their work (De Cuyper, Bernhard-Oettel, Berntson, De Witte, \& Alarco, 2008). 


\section{INFORMAL LEARNING FROM OTHERS: PROACTIVE FEEDBACK- AND HELP-}

\section{SEEKING}

Much recent research about learning and work has focused on learning opportunities outside education and training institutions (Kyndt \& Baert, 2013). For instance, this includes learning by doing, having discussions with colleagues, or engaging in reflection (Marsick, 2009). Several studies suggest that these learning activities are more efficient than attending seminars and workshops of education and training institutions (Berings, Poell, \& Simons, 2008; Billett, 2002; Eraut, 2007; Van der Heijden et al., 2009). The social aspect of learning in the workplace plays an especially important role (Billett, 1995; Boud \& Middleton, 2003; Eraut, 2007). Specifically, seeking feedback and help from others are important means of learning in the workplace (Bamberger, 2009) and may help to develop the competences needed to stay employable. Feedback-seeking is the proactive search for information targeted at evaluating and reflecting upon work processes and the self (Anseel, Lievens, \& Levy, 2007). This does not require a specific problem and may be rooted in motives such as achieving a goal or protecting one's ego (Ashford, Blatt, \& VandeWalle, 2003). Proactive feedback-seeking behavior has been mostly related to positive outcomes, such as goal attainment (Ammons, 1956) and performance (Kluger \& DeNisi, 1996). More recent research suggests that the feedback quality and not so much the quantity of it is important for learning and development (Van der Rijt, Van den Bossche, Van de Wiel, Segers, \& Gijselaers, 2012).

Help-seeking means the proactive search for assistance from others to solve a specific problem. Help seekers are, therefore, required to locate and define a problem, to think about persons who are accessible and knowledgeable regarding this problem, and to establish contact with these persons (Lee, 1997). Help-seeking has a long research tradition in the field of academic learning (Järvelä, 2011; Mäkitalo-Siegl \& Fischer, 2011). There, it is seen as an essential method to engage learners cognitively, behaviorally, and emotionally (Pintrich \& Zusho, 2002) and to contribute to resilience, efficacy, and learning (Karabenick \& Newman, 2006; Karabenick, 1998).

Informal learning from others in terms of proactive feedback and help-seeking may enhance employees' employability. For instance, employees may increase their knowledge about a relevant subject (i.e., 
enhance occupational expertise) or about processes in the organization (i.e., corporate sense). They may learn about trends (i.e., anticipation and optimization) that are central to effective work performance and how to react towards them (i.e., personal flexibility). Finally, by getting relevant and useful information, they may deem their working and learning to be more in balance. Previous empirical studies find positive relationships between informal learning from others and employability. For instance, Van der Heijden et al. (2009) have researched the relationship among non-academic university employees' networking behavior and their employability. They find that networking within and outside the home organization relates positively to employability. Moreover, the evidence suggests that interaction with one's supervisor may improve balance and corporate sense. The study was largely replicated among academic staff members by Van der Klink et al. (2014). There, networking enhanced anticipation and optimization, personal flexibility, and corporate sense. Additionally, Van der Rijt et al. (2012) report feedback-seeking to increase perceived career development among employees in the financial sector. Froehlich et al. (2014) also find that proactive search for information, feedback, and help improves occupational expertise, anticipation and optimization, and personal flexibility. Therefore, we hypothesize that informal learning from others in terms of feedback and help-seeking stands to improve employability. This then leads to our hypothesis:

Hypothesis 1: Informal learning from others positively affects employability in terms of occupational expertise, anticipation and optimization, personal flexibility, corporate sense, and balance.

\section{FUTURE TIME PERSPECTIVE}

According to the socioemotional selectivity theory (Carstensen, Isaacowitz, \& Charles, 1999), individuals select and pursue their goals in alignment with their (working) life's time horizon. Specifically, people with a limited future time perspective seek emotional well-being and short-term benefits. Conversely, people viewing time as open-ended value the acquisition of knowledge and skills more (Carstensen, 2006). Cate and John (2007) later found that adults might experience limitations and opportunities simultaneously. For instance, middle-aged adults become 
aware of physical decline (Lachman, Lewkowicz, Marcus, \& Peng, 1994), but also experience gains in confidence and generativity (Miner-Rubino, Winter, \& Stewart, 2004; Stewart, Ostrove, \& Helson, 2001). A one-dimensional conceptualization of future time perspective does not consider this. Therefore, Cate and John (2007) developed a two-factor solution that distinguishes in how far the future time is perceived as a time of opportunities and limitations.

Little empirical evidence exists for the relationship between future time perspective and informal learning from others. However, we know from educational psychology that an extensive future time perspective may be associated with, for instance, higher engagement (Horstmanshof \& Zimitat, 2007), an increased likelihood of completing tasks (Bembenutty \& Karabenick, 2004), increased persistence to study, and better academic performance (De Volder \& Lens, 1982). Likewise, Janeiro and Marques (2010) find future time orientation to be positively related to career attitudes among Portuguese pupils (Creager, 2011). Simons, Vansteenkiste, Lens, and Lacante (2004) and Miller and Brickman (2004) argue that the perception of more opportunities ahead increases the instrumentality of individuals' learning behavior. This, in turn, affects the motivation to learn. In a more general sense, Lang and Carstensen (2002) find effects of future time perspective on the composition of adults' social networks. Specifically, individuals who perceive the future as limited prefer emotional goals and, thus, are more likely to connect to relatives and formal partners. Contrarily, individuals who have an expansive perception of the future prefer to interact with knowledgeable or controversial partners to fulfill their desire for growth. This difference is attributable to the different goals associated with opportunity focus and limitation focus and might indicate an influence of opportunity focus and limitation focus on informal learning from others. We hypothesize that opportunity focus stimulates learning from others in terms of feedback- and help-seeking and, in turn, strengthens employees' employability. Conversely, we hypothesize that limitation focus deters learning from others and hence weakens employees' employability.

Hypothesis 2: Opportunity focus positively affects employability in terms of occupational expertise, anticipation and optimization, personal 
flexibility, corporate sense, and balance via informal learning from others.

Hypothesis 3: Limitation focus negatively affects employability in terms of occupational expertise, anticipation and optimization, personal flexibility, corporate sense, and balance via informal learning from others.

Figure 1 displays the research model.

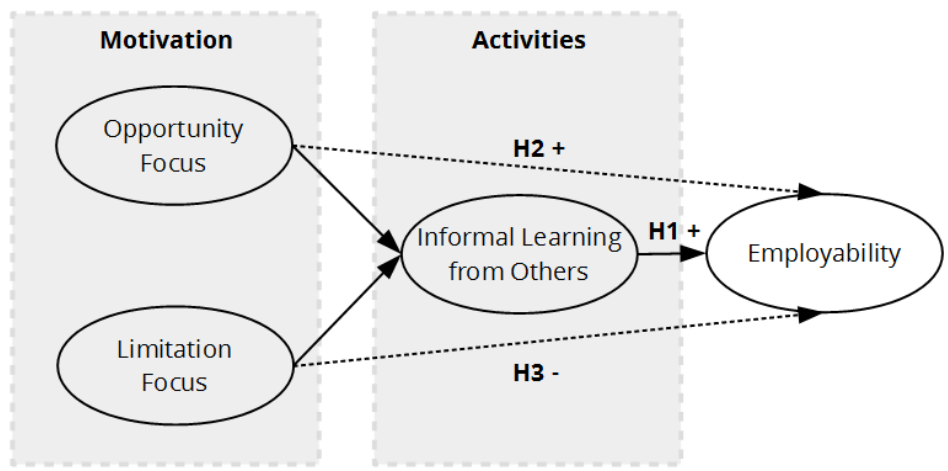

Figure 1: Research model of this chapter.

\section{MeTHODS}

\section{Participants}

We sent electronic questionnaires to 215 randomly selected employees of two Austrian consultancies. The first organization generates its profits predominantly in the domain of information technology $(n=77$; response rate $=72 \%$ ). The second organization is a not-for-profit organization and offers a wider array of consulting services, including, for instance, consultations about international law and policy $(n=90$, response rate $=83 \%$ ). In both organizations, the respondents work in project teams to provide consulting services directly to their clients. Consultancies are an interesting setting for this study due to the industry-specific demand for employability (Petersitzke \& Hristozova, 2006). For example, consulting knowledge needs to very current and yet it depreciates rapidly (Kubr, 2002). In addition, consultants need to adapt quickly to new clients and their different structures and cultures. Since the respondents of both 
organizations are similar in terms of type of work and the national and professional culture they are embedded in, we merged the two samples for the analyses. The respondents were 18 to 59 years old $(M=40.80, S D=$ 9.88). 93 (56\%) have obtained a higher education degree; 86 (52\%) were female. Analysis of variance (ANOVA) showed a difference between the samples in terms of gender $(F(1,165)=11.58, p \leq 0.01)$, which can be explained by the traditionally male-dominated IT sector. No differences were found for age or degrees from higher education.

\section{Instruments}

We gauged the dimensions of employability using Van der Heijde and Van der Heijden's (2006) instrument of 47 items. In line with our conceptualization of self-appraised employability, respondents assessed their own employability on a 5-point Likert-scale ( 1 = strongly disagree, 5 = strongly agree). We randomly assigned each item to one of three parcels per dimension to achieve a better relation between the number of parameters and the given sample size in the analyses (Little, Cunningham, Shahar, \& Widaman, 2002). This model achieved good fit; all scales achieved satisfactory Cronbach's alphas. Table 1 shows fit indices, reliability estimates, and sample items. 
Table 1: Overview over the scales used.

\begin{tabular}{|c|c|c|c|c|}
\hline Scale & Items & $\mathbf{a}$ & Sample item & Model fit \\
\hline $\begin{array}{l}\text { Occupational } \\
\text { Expertise }\end{array}$ & 15 & .92 & $\begin{array}{l}\text { I consider myself competent } \\
\text { to engage in in-depth, } \\
\text { specialist discussions in my } \\
\text { job domain. }\end{array}$ & \\
\hline $\begin{array}{l}\text { Anticipation \& } \\
\text { Optimization }\end{array}$ & 8 & .74 & $\begin{array}{l}\text { I take responsibility for } \\
\text { maintaining my labor market } \\
\text { value. }\end{array}$ & $\begin{array}{l}\mathrm{CFI}=.95 \\
\mathrm{RMSEA}=.07 \\
\mathrm{SRMR}=.06\end{array}$ \\
\hline $\begin{array}{l}\text { Personal } \\
\text { Flexibility }\end{array}$ & 8 & .77 & $\begin{array}{l}\text { I adapt to developments } \\
\text { within my organization. }\end{array}$ & $\begin{array}{l}\chi^{2} / \mathrm{df}=145 / 80 \\
=1.81\end{array}$ \\
\hline $\begin{array}{l}\text { Corporate } \\
\text { Sense }\end{array}$ & 7 & .80 & $\begin{array}{l}\text { I am involved in achieving my } \\
\text { organization's mission. }\end{array}$ & \\
\hline Balance & 9 & .71 & $\begin{array}{l}\text { My working, learning, and } \\
\text { living are in harmony. }\end{array}$ & \\
\hline $\begin{array}{l}\text { Opportunity } \\
\text { Focus }\end{array}$ & 7 & .91 & $\begin{array}{l}\text { Many work opportunities } \\
\text { await me in the future. }\end{array}$ & $\begin{array}{l}\mathrm{CFI}=.97 \\
\mathrm{RMSEA}=.07\end{array}$ \\
\hline $\begin{array}{l}\text { Limitation } \\
\text { Focus }\end{array}$ & 3 & .68 & $\begin{array}{l}\text { I have the sense that my time } \\
\text { in the working life is running } \\
\text { out. }\end{array}$ & $\begin{array}{l}\text { SRMR }=.04 \\
\chi^{2} / d f=21 / 14= \\
1.77\end{array}$ \\
\hline $\begin{array}{l}\text { Informal } \\
\text { Learning } \\
\text { from Others }\end{array}$ & 8 & .79 & $\begin{array}{l}\text { Getting help would be one of } \\
\text { the first things I would do if I } \\
\text { were having trouble at work. }\end{array}$ & $\begin{array}{l}\text { CFI = 1.00, } \\
\text { RMSEA = .00, } \\
\text { SRMR }=.00, \\
\chi^{2} / d f=- \\
\text { (just } \\
\text { identified) }\end{array}$ \\
\hline
\end{tabular}

Note: All scales were measured using 5-point Likert scales. All factor loadings of the measurement models were $\geq .70$.

We assessed opportunity focus and limitation focus using Lang and Carstensen's (2002) 10-item future time perspective scale, which was reworded to refer to the working life. Respondents answered on a 5-point Likert-scale (1 = strongly disagree, 5 = strongly agree). The two-factor solution 
proposed by Cate and John (2007) fit our data better than a one-factor or three-factor solution; the reliabilities are acceptable (Table 1).

We used Froehlich et al.'s (2014) scales of feedback and help-seeking behaviors from supervisors and colleagues to measure informal learning from others. Respondents answered on a 5-point Likert-scale $(1=$ almost never, 5 = very often); all eight items were collapsed into one scale. We used three parcels to identify informal learning from others. The scale achieved satisfactory reliability; the model is just identified (Table 1).

We used chronological age and hours spent in formal education activities as covariates in our model. We asked for both using open questions.

\section{Analyses}

We checked and confirmed that the dataset does not contain any missing data. Then, we explored the relations between the variables in bivariate correlation analyses. Last, we tested the hypotheses using structural equation modeling using Maximum Likelihood estimation in Mplus 7.11 (Muthén \& Muthén, 2012). Model fit was assessed using the comparative fit index ( $\mathrm{CFl}$, acceptable if $\geq 0.90$ ), the root mean square error of approximation (RMSEA, acceptable if $\leq 0.07$ ), the standardized root mean squared residual (SRMR, acceptable if $\leq 0.08$ ), and the ratio of $\chi^{2}$ to the degrees of freedom (acceptable if $\leq 3.00$; Hoyle, 1995; Hu \& Bentler, 1999).

\section{RESULTS}

Table 2 presents findings characterized by medium to strong positive correlations among the dimensions of employability $(r=0.28$ to $0.59, p<0.01)$, strong negative correlations of opportunity focus with limitation focus $(r=-0.64, p<0.01)$ and chronological age $(r=-0.70, p<0.01)$, and positive correlations of informal learning from others with the dimensions of employability $(r=0.17, p<0.05$ to $r=0.31, p<0.01)$. These findings are in line with our hypotheses.

The structural equation modeling analyses showed acceptable model fit: $\mathrm{CFI}=0.90, \mathrm{RMSEA}=0.07, \mathrm{SRMR}=0.07$, and $\chi^{2} / \mathrm{df}=505 / 287=1.76$. All factor loadings of the measurement model were $\geq 0.70$. In our sample, informal learning from others positively affects anticipation and 
optimization ( $B=1.30,99 \% \mathrm{CI}[0.12,6.06]$; see Table 3$)$, personal flexibility ( $B$ $=1.45,99 \% \mathrm{CI}[0.27,6.47])$, corporate sense $(\mathrm{B}=1.36,99 \% \mathrm{CI}[0.26,7.41])$, and balance $(B=0.70,99 \% \mathrm{Cl}[0.16,4.19])$. This gives partial support to Hypothesis 1.

We also noted effects of chronological age on occupational expertise $(B=0.01,95 \% C I[>0.00,0.02])$ and corporate sense $(B=0.02,99 \% C I[>0.00$, $0.07])$. Attending formal learning activities and the employing organization did not cause significant differences.

We found indirect effects of opportunity focus via informal learning from others on anticipation and optimization ( $B=0.34,95 \% \mathrm{CI}[0.02,2.25])$ and balance $(B=0.18,95 \% C l[0.05,1.54])$. Furthermore, we found weaker effects on personal flexibility $(B=0.37,90 \% C I[0.11,0.76])$ and corporate sense $(B=0.35,90 \% C I[0.11,0.89])$. This gives partial support to Hypothesis 2. Conversely, we found no indirect effects of limitation focus. Thus, Hypothesis 3 receives no support. 


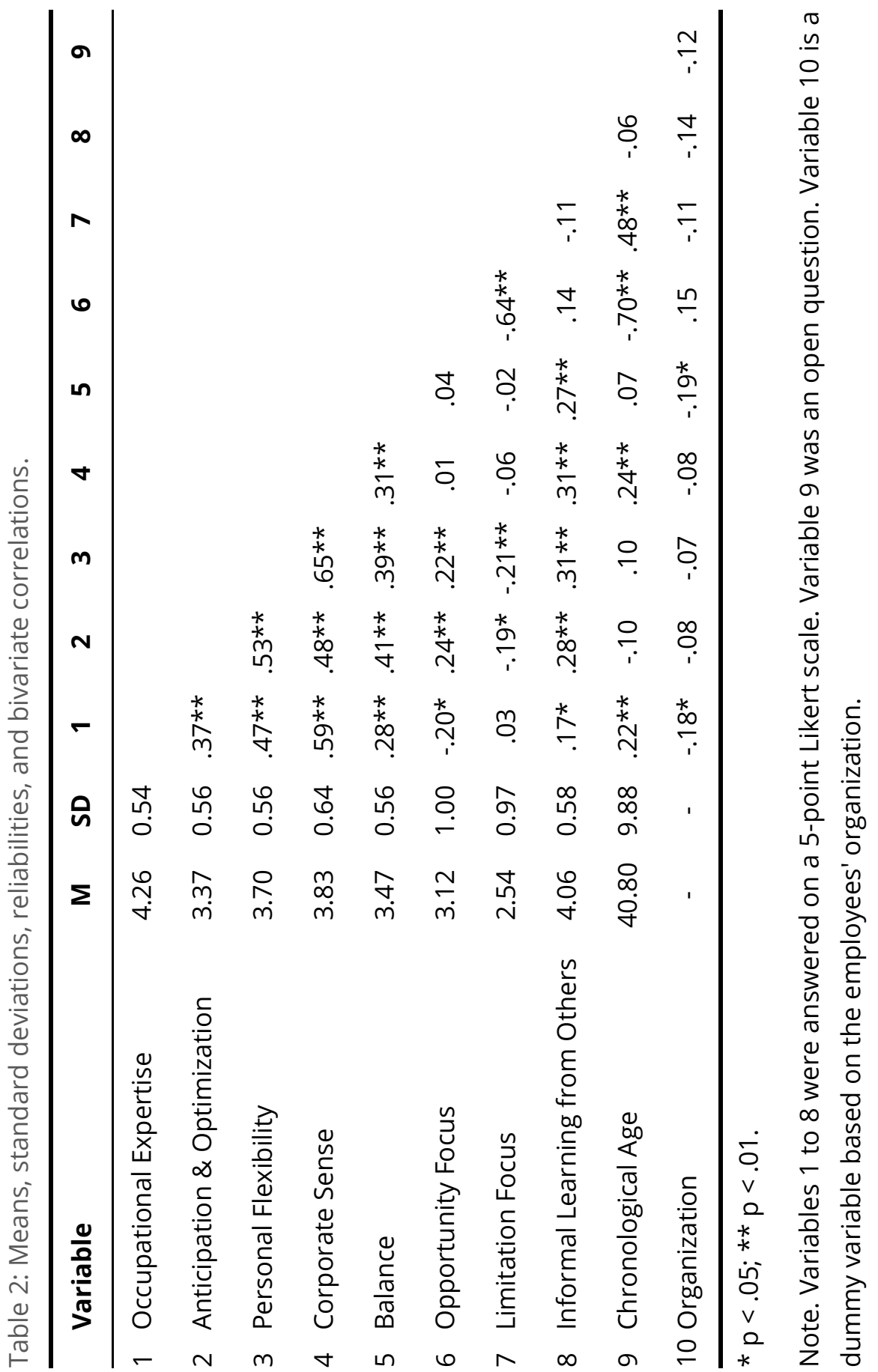


ChAPTER 5 | 133

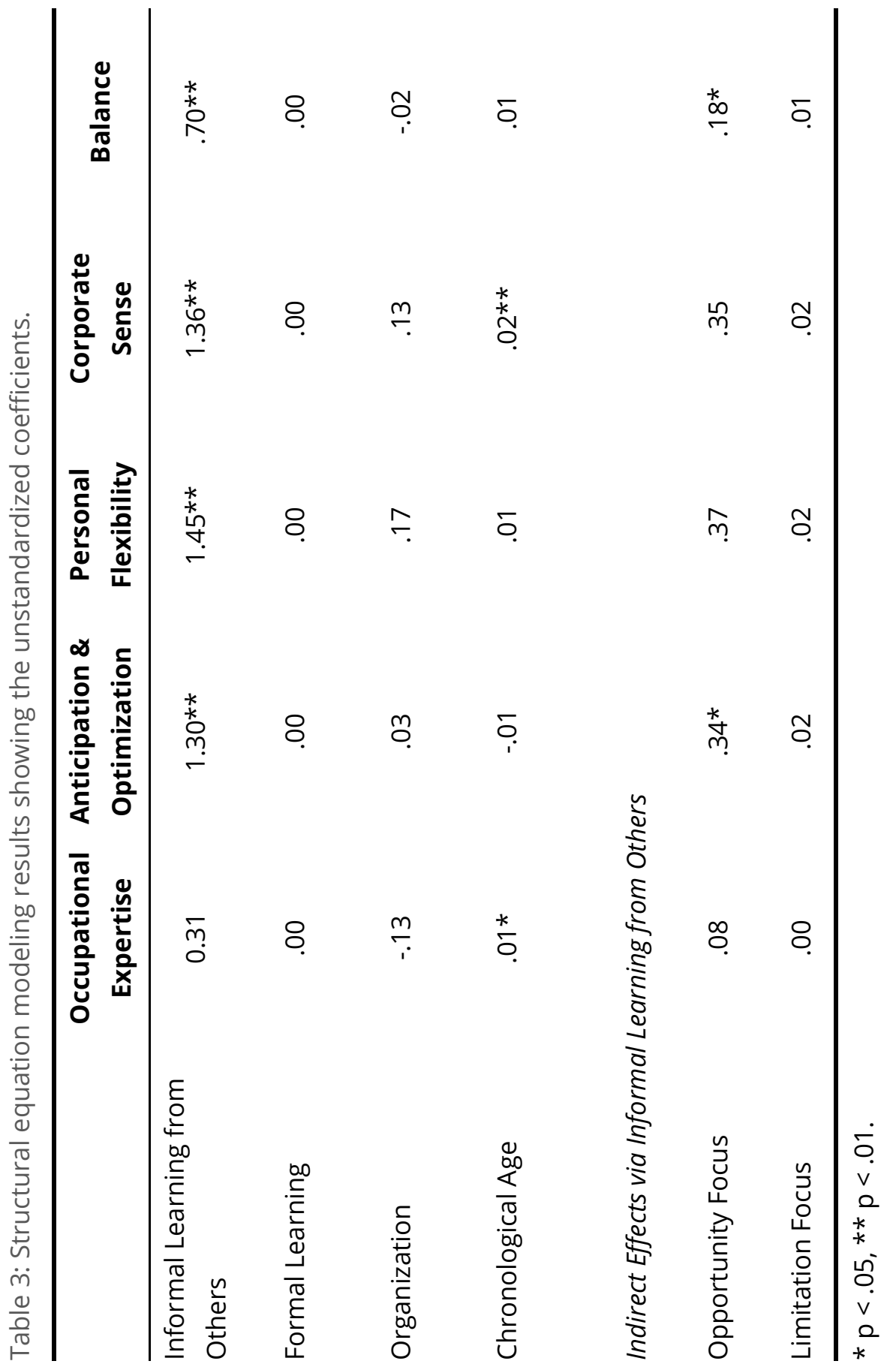




\section{Discussion}

We set out to investigate how opportunity focus and limitation focus influence employability via informal learning from others in terms of feedback- and help-seeking. This is important, because the role of personal factors for the enhancement of employability in the context of the demographic shift has received little attention so far (Froehlich, Beausaert, \& Segers, 2014; Raemdonck et al., 2015). This information may be crucial to understand the different trajectories of older employees' employability. Why do some employees manage to stay on top of current developments while others fail to advance their employability? We hypothesized that opportunity focus has positive indirect effects on employability via informal learning from others, while limitation focus has negative indirect effects. We have found positive relationships between informal learning from others and four dimensions of employability: anticipation and optimization, personal flexibility, corporate sense, and balance. This is consistent with previous research (Froehlich, Beausaert, Segers, et al., 2014; Van der Heijden et al., 2009; Van der Klink et al., 2014) and supports the claim that learning activities in general and informal learning from others in particular are apt means of developing employability. Opportunity focus, which stimulates informal learning from others, has been found to have indirect positive effects on employability. In other words, the perceptions of many opportunities in one's future working life triggers informal learning from others and, in turn, helps employees to enhance their employability. Given the strong correlations between chronological age and future time perspective found in previous research (e.g., Lang \& Carstensen, 2002), this finding has important implications for the development of employability in the context of an aging workforce.

First, the findings have implications for further research. Future time perspective is an interesting personal factor to study the development of employability of an aging workforce. This is important, as the low employment rates among older people (OECD, 2014) raise questions about the learning behavior and employability of older employees. However, previous research in the fields of learning and employability struggles to answer these questions, as employee age and the change in future time perspective associated with it have often been ignored. Future research 
should be more sensitive to the changes associated with aging and their effects on learning within organizations. This calls for the inclusion of other conceptualizations of age, next to chronological age (Maurer, Weiss, \& Barbeite, 2003; Raemdonck et al., 2015), which is often criticized on the grounds of two conceptual problems. First, chronological age is used as a proxy measure for many factors related to aging, such as physical changes, age-related stereotypes, or effects specific to a certain cohort (Hall, Mairesse, \& Turner, 2007). These effects are difficult to disentangle from each other. Second, the more experiences people have made in their lives, the more heterogeneous they are (Carstensen, 2006; Staudinger \& Bowen, 2011). This weakens the predictive power of chronological age. The study presented here has shown that future time perspective may be an interesting alternative to the use of chronological age as a predictor for engagement in learning activities and employability. Older employees, after all, are not a homogeneous group of people (Bal \& Jansen, 2015) - personal factors matter.

Second, implications for practice may be derived from the role that opportunity focus and limitation focus play in our model. The findings suggest that it is an essential task of human resource development managers to develop an opportunity focus across the workforce. Unfortunately, organizational research offers little advice of how this may be accomplished. But research in other fields, such as education and health science, hints at potential solutions. For instance, clarifying the instrumentality of any learning activity for future success beforehand (Simons et al., 2004), communicating the role of work-related learning and personal goals (Phalet, Andriessen, \& Lens, 2004), or facilitating long-term planning (Gellert, Ziegelmann, Lippke, \& Schwarzer, 2012) might help. Also, the use of long-term personal development plans may support this development (Beausaert, Segers, Van der Rijt, \& Gijselaers, 2011). As opportunity focus is a function of chronological age, it may also be relevant to educate against ageism, for instance by fostering high-quality intergenerational contact (Iweins, Desmette, Yzerbyt, \& Stinglhamber, 2013) or offering age awareness trainings (Armstrong-Stassen \& Templer, 2005).

Future research may improve and extend this study in terms of measurement and generalizability. In this study, the employees self- 
assessed their employability. But previous research has found that employees rate themselves higher than their employers do (Van der Heijde \& Van der Heijden, 2006) and higher than their labor market success would suggest (Patrickson \& Ranzijn, 2003). Our conceptualization of employability as perceived employability, however, is in line with previous research (Kinnunen et al., 2011; Van Emmerik et al., 2012). Nevertheless, to test for common method bias (Podsakoff \& Organ, 1986), further research may include also other sources for assessing the variables.

We have executed this study in the consultancy sector. We believe that the industry-specific demands for employability (Petersitzke \& Hristozova, 2006) make it an interesting setting for our study. At the same time, these industry-specific affordances may limit the generalizability of this research's finding. Thus, further research may replicate this study in different sectors.

In conclusion, the study reported and discussed here offers first evidence for an indirect effect of opportunity focus on employability via informal learning from others. It presents future time perspective as an alternative variable to the use of chronological age to research learning and employability in the context of an aging workforce. Furthermore, it implies that the concept of future time perspective may also be addressed by human resource practitioners in order to prepare their company for an older, but still highly employable, workforce. 


\section{REFERENCES}

Ahmed, A. M., Andersson, L., \& Hammarstedt, M. (2012). Does age matter for employability? A field experiment on ageism in the Swedish labour market. Applied Economics Letters, 19(4), 403-406. doi:10.1080/13504851.2011.581199

Albert, R., Escot, L., \& Fernández-Cornejo, J. A. (2011). A field experiment to study sex and age discrimination in the Madrid labour market. International Journal of Human Resource Management, 22(2), 351-375. doi:10.1080/09585192.2011.540160

Ammons, R. B. (1956). Effects of Knowledge of Performance: A Survey and Tentative Theoretical Formulation. Journal of General Psychology, 54(2), 279-299. doi:10.1080/00221309.1956.9920284

Anderson, L. B. (2013). How frames present BMW as embracing an aging workforce. Public Relations Review, 39(5), 484-490. doi:10.1016/j.pubrev.2013.02.003

Anseel, F., Lievens, F., \& Levy, P. E. (2007). A Self-motives Perspective on Feedback-seeking Behavior: Linking Organizational Behavior and Social Psychology Research. International Journal of Management Reviews, 9(3), 211-236. doi:10.1111/j.1468-2370.2007.00210.x

Armstrong-Stassen, M., \& Templer, A. (2005). Adapting Training for Older Employees: The Canadian Response to an Aging Workforce. Journal of Management Development, 24(1), 57-67. doi:10.1108/02621710510572353

Ashford, S. J., Blatt, R., \& VandeWalle, D. (2003). Reflections on the Looking Glass: A Review of Research on Feedback-Seeking Behavior in Organizations. Journal of Management, 29(6), 773-799. doi:10.1016/S0149-2063(03)00079-5

Bal, P. M., \& Jansen, P. G. W. (2015). Idiosyncratic Deals for Older Workers: Increased Heterogeneity Among Older Workers Enhance the Need for I-Deals. In P. M. Bal, D. T. A. M. Kooij, \& D. M. Rousseau (Eds.), Aging Workers and the Employee-Employer Relationship (pp. 129-144). Cham: Springer Netherlands. doi:10.1007/978-3-319-08007-9_8 
Bamberger, P. A. (2009). Employee Help-Seeking: Antecedents, Consequences and new Insights for Future Research. In J. J. Martocchio \& H. Liao (Eds.), Research in Personnel and Human Resource Management (Vol. 28, pp. 49-98). Bingley: Emerald Group Publishing. doi:10.1108/S0742-7301(2009)0000028005

Beausaert, S. A. J., Segers, M. S. R., Van der Rijt, J., \& Gijselaers, W. H. (2011). The Use of Personal Development Plans (PDPs) in the Workplace: A Literature Review. In P. Van den Bossche, W. H. Gijselaers, \& R. G. Milter (Eds.), Building Learning Experiences in a Changing World (Vol. 3, pp. 235265). Dordrecht: Springer Netherlands. doi:10.1007/978-94-007-0802-0

Bembenutty, H., \& Karabenick, S. A. (2004). Inherent Association Between Academic Delay of Gratification, Future Time Perspective, and SelfRegulated Learning. Educational Psychology Review, 16(1), 35-57. doi:10.1023/B:EDPR.0000012344.34008.5c

Berings, M. G. M. C., Poell, R. F., \& Simons, P. R.-J. (2008). Dimensions of Onthe-Job Learning Styles. Applied Psychology: An International Review, 57(3), 417-440. doi:10.1111/j.1464-0597.2008.00362.x

Berntson, E., \& Marklund, S. (2007). The Relationship Between Employability and Subsequent Health. Work \& Stress, 21(3), 279-292. doi:10.1080/02678370701659215

Billett, S. (1995). Workplace learning: its potential and limitations. Education and Training, 37(4), 20-27.

Billett, S. (2002). Towards a Workplace Pedagogy: Guidance, Participation and Engagement. Adult Education Quarterly, 53(1), 27-43. doi:10.1177/074171302237202

Billett, S. (2011). Promoting Lifelong Employability for Workforce Aged Over 45: Singaporean Workers' Perspectives. International Journal of Continuing Education and Lifelong Learning, 3(2), 57-73.

Billett, S., \& Van Woerkom, M. (2008). Personal Epistemologies and Older Workers. International Journal of Lifelong Learning, 27(3), 333-348.

Boud, D., \& Middleton, H. (2003). Learning from others at work: communities of practice and informal learning. Journal of Workplace Learning, 15(5), 194-202. doi:10.1108/13665620310483895 
Carstensen, L. L. (2006). The Influence of a Sense of Time on Human Development. Science, 312(5782), 1913-1915. doi:10.1126/science.1127488

Carstensen, L. L., Isaacowitz, D. M., \& Charles, S. T. (1999). Taking Time Seriously: A Theory of Socioemotional Selectivity. American Psychologist, 54(3), 165-181. doi:10.1037/0003-066X.54.3.165

Cate, R. A., \& John, O. P. (2007). Testing Models of the Structure and Development of Future Time Perspective: Maintaining a Focus on Opportunities in Middle Age. Psychology and Aging, 22(1), 186-201. doi:10.1037/0882-7974.22.1.186

Creager, M. F. S. (2011). Practice and Research in Career Counseling and Development - 2010. Career Development Quarterly, 59(4), 482-528. doi:10.1002/j.2161-0045.2011.tb00973.x

De Cuyper, N., Bernhard-Oettel, C., Berntson, E., De Witte, H., \& Alarco, B. (2008). Employability and Employees' Well-Being: Mediation by Job Insecurity. Applied Psychology, 57(3), 488-509.

De Lange, A. H., Bal, P. M., Van der Heijden, B. I. J. M., De Jong, N., \& Schaufeli, W. B. (2011). When I'm 64: Psychological Contract Breach, Work Motivation and the Moderating Roles of Future Time Perspective and Regulatory Focus. Work \& Stress, 25(4), 338-354. doi:10.1080/02678373.2011.632610

De Volder, M. L., \& Lens, W. (1982). Academic Achievement and Future Time Perspective as a Cognitive-Motivational Concept. Journal of Personality and Social Psychology, 42(3), 566-571. doi:10.1037//0022-3514.42.3.566

Eraut, M. (2007). Learning from Other People in the Workplace. Oxford Review of Education, 33(4), 403-422. doi:10.1080/03054980701425706

European Commission. (2012). An Agenda for Adequate, Safe and Sustainable Pensions. Brussels: European Commission.

Finkelstein, L. M., King, E. B., \& Voyles, E. C. (2015). Age Metastereotyping and Cross-Age Workplace Interactions: A Meta View of Age Stereotypes at Work. Work, Aging and Retirement, 1(1), 26-40. doi:10.1093/workar/wau002 
Froehlich, D. E., Beausaert, S. A. J., \& Segers, M. S. R. (2014). Age, employability and the role of learning activities and their motivational antecedents: a conceptual model. International Journal of Human Resource Management, 1-15. doi:10.1080/09585192.2014.971846

Froehlich, D. E., Beausaert, S. A. J., Segers, M. S. R., \& Gerken, M. (2014). Learning to Stay Employable. Career Development International, 19(5), 508-525. doi:10.1108/CDI-11-2013-0139

Fugate, M., Kinicki, A. J., \& Ashforth, B. E. (2004). Employability: A psychosocial construct, its dimensions, and applications. Journal of Vocational Behavior, 65(1), 14-38. doi:10.1016/j.jvb.2003.10.005

Gegenfurtner, A., \& Vauras, M. (2012). Age-related differences in the relation between motivation to learn and transfer of training in adult continuing education. Contemporary Educational Psychology, 37(1), 3346. doi:10.1016/j.cedpsych.2011.09.003

Gellert, P., Ziegelmann, J. P., Lippke, S., \& Schwarzer, R. (2012). Future time perspective and health behaviors: temporal framing of self-regulatory processes in physical exercise and dietary behaviors. Annals of Behavioral Medicine, 43(2), 208-18. doi:10.1007/s12160-011-9312-y

Hall, B. H., Mairesse, J., \& Turner, L. (2007). Identifying age, cohort, and period effects in scientific research productivity: discussion and illustration using simulated and actual data on french physicists. Economics of Innovation and New Technology, 16(2), 37-41.

Horstmanshof, L., \& Zimitat, C. (2007). Future time orientation predicts academic engagement among first-year university students. British Journal of Educational Psychology, 77(3), 703-718. doi:10.1348/000709906×160778

Hoyle, R. H. (1995). Structural equation modeling: Concepts, issues, and applications. Thousand Oaks, CA: Sage.

Hu, L., \& Bentler, P. M. (1999). Cutoff criteria for fit indexes in covariance structure analysis: Conventional criteria versus new alternatives. Structural Equation Modeling, 6(1), 1-55.

Iweins, C., Desmette, D., Yzerbyt, V., \& Stinglhamber, F. (2013). Ageism at work: The impact of intergenerational contact and organizational multi- 
age perspective. European Journal of Work and Organizational Psychology, 22(3), 331-346. doi:10.1080/1359432X.2012.748656

Janeiro, I. N., \& Marques, J. F. (2010). Career coping styles: differences in career attitudes among secondary school students. International Journal for Educational and Vocational Guidance, 10(1), 35-48. doi:10.1007/s10775-009-9170-3

Järvelä, S. (2011). How does help seeking help? - New prospects in a variety of contexts. Learning and Instruction, 21(2), 297-299. doi:10.1016/j.learninstruc.2010.07.006

Karabenick, S. A. (1998). Strategic Help-seeking: Implications for Learning and Teaching. Mahwah: Erlbaum.

Karabenick, S. A., \& Newman, R. S. (2006). Help Seeking in Academic Settings: Goals, Groups, and Contexts. Mahwah: Erlbaum.

Kim, D. S., \& Mo, S. H. (2014). Stereotypical Beliefs on Old Korean Workers. Ageing International. doi:10.1007/s12126-014-9200-4

Kinnunen, U., Mäkikangas, A., Mauno, S., Siponen, K., \& Nätti, J. (2011). Perceived employability: Investigating outcomes among involuntary and voluntary temporary employees compared to permanent employees. Career Development International, 16(2), 140-160. doi:10.1108/13620431111115604

Kluger, A. N., \& DeNisi, A. (1996). The Effects of feedback intervention on performance: A historical review, a meta-analysis, and a preliminary feedback intervention theory. Psychological Bulletin, 119(2), 254-284. doi:10.1037/0033-2909.119.2.254

Kooij, D. T. A. M., Bal, P. M., \& Kanfer, R. (2014). Future time perspective and promotion focus as determinants of intraindividual change in work motivation. Psychology and Aging, 29(2), 319-328.

Kubr, M. (2002). Management Consulting: A Guide to the Profession (4th ed.). Geneva: International Labour Office.

Kyndt, E., \& Baert, H. (2013). Antecedents of Employees' Involvement in Work-Related Learning: A Systematic Review. Review of Educational Research, 83(2), 273-313. doi:10.3102/0034654313478021 
Lachman, M. E., Lewkowicz, C., Marcus, A., \& Peng, Y. (1994). Images of midlife development among young, middle-aged, and older adults. Journal of Adult Development, 1(4), 201-211. doi:10.1007/BF02277581

Lang, F. R., \& Carstensen, L. L. (2002). Time counts: Future time perspective, goals, and social relationships. Psychology and Aging, 17(1), 125-139. doi:10.1037//0882-7974.17.1.125

Lazarus, R. S., \& Folkman, S. (1984). Stress, Appraisal, and Coping. New York: Springer.

Lee, F. (1997). When the Going Gets Tough, Do the Tough Ask for Help? Help Seeking and Power Motivation in Organizations. Organizational Behavior and Human Decision Processes, 72(3), 336-63.

Little, T. D., Cunningham, W. A., Shahar, G., \& Widaman, K. F. (2002). To Parcel or Not to Parcel: Exploring the Question, Weighing the Merits. Structural Equation Modeling, 9(2), 151-173. doi:10.1207/S15328007SEM0902_1

Mäkitalo-Siegl, K., \& Fischer, F. (2011). Stretching the limits in help-seeking research: Theoretical, methodological, and technological advances. Learning and Instruction, 21(2), 243-246. doi:10.1016/j.learninstruc.2010.07.002

Marsick, V. J. (2009). Toward a Unifying Framework to Support Informal Learning Theory, Research and Practice. Journal of Workplace Learning, 21(4), 265-275. doi:10.1108/13665620910954184

Maurer, T. J., Weiss, E. M., \& Barbeite, F. G. (2003). A model of involvement in work-related learning and development activity: The effects of individual, situational, motivational, and age variables. Journal of Applied Psychology, 88(4), 707-724. doi:10.1037/0021-9010.88.4.707

Meyers, R., Billett, S., \& Kelly, A. (2010). Mature-aged workers' learning needs and motivations for participation in training programs. International Journal of Training Research, 8(2), 116-127. doi:10.5172/ijtr.8.2.116

Midtsundstad, T. I., \& Bogen, H. (2014). Active Aging Policies between Individual Needs and Collective Goods. A Study of Active Aging Policies and Practices in Norway. Nordic Journal of Working Life Studies, 4(2), 139-158. 
Miller, R. B., \& Brickman, S. J. (2004). A Model of Future-Oriented Motivation. Educational Psychology, 16(1).

Miner-Rubino, K., Winter, D. G., \& Stewart, A. J. (2004). Gender, social class, and the subjective experience of aging: self-perceived personality change from early adulthood to late midlife. Personality \& Social Psychology Bulletin, 30(12), 1599-610. doi:10.1177/0146167204271178

Muthén, L. K., \& Muthén, B. O. (2012). MPlus. Los Angeles, CA: Muthén \& Muthén.

OECD. (2012). OECD Environmental Outlook to 2050. Paris: OECD Publishing. doi:10.1787/9789264122246-en

OECD. (2014). OECD.Stat Database. doi:10.1787/20752342

Patrickson, M., \& Ranzijn, R. (2003). Employability of Older Workers. Equal Opportunities International, 22(5),

50-63. doi:10.1108/02610150310787496

Petersitzke, M., \& Hristozova, E. (2006). Managing Employability in the German Consultancy Industry. In M. E. Domsch \& E. Hristozova (Eds.), Human Resource Management in Consulting Firms (pp. 191-211). Berlin: Springer.

Phalet, K., Andriessen, I., \& Lens, W. (2004). How Future Goals Enhance Motivation and Learning in Multicultural Classrooms. Educational Psychology Review, 16(1), 59-89. doi:10.1023/B:EDPR.0000012345.71645.d4

Pintrich, P. R., \& Zusho, A. (2002). The Development of Academic Selfregulation: The Role of Cognitive and Motivational Factors. In A. Wigfield \& J. S. Eccles (Eds.), Development of Achievement Motivation (pp. 249-284). San Diego: Academic Press. doi:10.1016/B978-0127500539/50012-7

Podsakoff, P. M., Ahearne, M., \& Mackenzie, S. B. (1997). Organizational citizenship behavior and the quantity and quality of work group performance. Journal of Applied Psychology, 82(2), 262-70.

Podsakoff, P. M., \& Organ, D. W. (1986). Self-Reports in Organizational Research: Problems and Prospects. Journal of Management, 12(4), 531544. doi:10.1177/014920638601200408 
Raemdonck, I., Beausaert, S. A. J., Froehlich, D. E., Kochoian, N., \& Meurant, C. (2015). Age related changes in learning and employability. In D. Rosseau, D. T. A. M. Kooij, \& P. M. Bal (Eds.), Aging Workers and the Employee-Employer Relationship (pp. 163-184).

Rodriguez, D., Patel, R., Bright, A., Gregory, D., \& Gowing, M. K. (2002). Developing competency models to promote integrated human resource practices. Human Resource Management, 41(3), 309-324. doi:10.1002/hrm.10043

Sanders, J., \& De Grip, A. (2004). Training, Task Flexibility and Low-Skilled Workers' Employability. International Journal of Manpower, 25(1), 73-89. doi:10.1108/01437720410525009

Simons, J., Vansteenkiste, M., Lens, W., \& Lacante, M. (2004). Placing Motivation and Future Time Perspective Theory in a Temporal Perspective. Educational Psychology Review, 16(2), 121-139. doi:10.1023/B:EDPR.0000026609.94841.2f

Staudinger, U. M., \& Bowen, C. E. (2011). A systemic approach to aging in the work context. Zeitschrift für ArbeitsmarktForschung, 44(4), 295-306. doi:10.1007/s12651-011-0086-2

Stewart, A. J., Ostrove, J. M., \& Helson, R. (2001). Middle Aging in Women: Patterns of Personality Change from the 30 s to the 50s. Journal of Adult Development, 8(1), 23-37.

Van der Heijde, C. M., \& Van der Heijden, B. I. J. M. (2006). A competencebased and multidimensional operationalization and measurement of employability. Human Resource Management, 45(3), 449-476. doi:10.1002/hrm.20119

Van der Heijden, B. I. J. M., Boon, J., Van der Klink, M. R., \& Meijs, E. (2009). Employability Enhancement through Formal and Informal Learning: An Empirical Study among Dutch Non-Academic University Staff Members. International Journal of Training and Development, 13(1), 19-37. doi:10.1111/j.1468-2419.2008.00313.x

Van der Klink, M. R., Van der Heijden, B. I. J. M., Boon, J., \& Williams van Rooij, S. (2014). Exploring the contribution of formal and informal learning to academic staff member employability. Career Development International, 19(3), 337-356. doi:10.1108/CDI-03-2013-0030 
Van der Rijt, J., Van den Bossche, P., Van de Wiel, M. W. J., Segers, M. S. R., \& Gijselaers, W. H. (2012). The role of individual and organizational characteristics in feedback-seeking behaviour in the initial career stage. Human Resource Development International, 15(3), 283-301. doi:10.1080/13678868.2012.689216

Van Emmerik, H., Schreurs, B., De Cuyper, N., Jawahar, I. M., \& Peeters, M. C. W. (2012). The route to employability: Examining resources and the mediating role of motivation. Career Development International, 17(2), 104-119. doi:10.1108/13620431211225304

Walker, A., \& Maltby, T. (2012). Active ageing: A strategic policy solution to demographic ageing in the European Union. International Journal of Social Welfare, 21, S117-S130. doi:10.1111/j.1468-2397.2012.00871.x

Wright, P. M., \& Snell, S. A. (1998). Toward a Unifying Framework for Exploring Fit and Flexibility in Strategic Human Resource Management. Academy of Management Review, 23(4), 756-772.

Zacher, H., Heusner, S., Schmitz, M., Zwierzanska, M. M., \& Frese, M. (2010). Focus on opportunities as a mediator of the relationships between age, job complexity, and work performance. Journal of Vocational Behavior, 76(3), 374-386. doi:10.1016/j.jvb.2009.09.001 
146 | GREAT EXPECTATIONS 


\section{CHAPTER 6}

\section{Feedback-Seeking in the Personal Network: The Effects on Employability and the Perils of Homophily*}

* This chapter is based on: Froehlich, D. E., Beausaert, S. A. J., \& Segers, M. S. R. (In review). Feedback Seeking in the Personal Network: The Effects on Employability and the Perils of Homophily

The paper was selected for a paper development workshop incl. scholarship sponsored by the Journal of Management Studies (2015).

Froehlich, D. E., Beausaert, S. A. J., \& Segers, M. S. R. (2014). Feedback Seeking in the Personal Network: The Effects on Employability and the Dangers of Homophily. Paper presented at the EARLI SIG 14. Oslo. doi:http://dx.doi.org/10.6084/m9.figshare.1157255

Froehlich, D. E., Beausaert, S. A. J., \& Segers, M. S. R. (2015). Learning to Stay Employable: The Role of Employees' Feedback Seeking Network and the Dangers of Homophily. Paper presented at the XXXV Sunbelt Conference of the International Network for Social Network Analysis (INSNA). Brighton. 


\section{ABstract}

Employees' feedback-seeking networks at work are important for employees' learning and employability. Previous studies, however, have often neglected the specificities of the different relationships a single employee has at work. We conduct social network analyses in six samples to study these relationships in detail. We investigate 1,948 feedback-seeking relationships of 107 employees in Austria, India, and the Netherlands and study how homophily affects the composition of feedback-seeking networks at work and how the composition of these feedback-seeking networks influences employees' employability. Results of a meta-analysis across all samples show that homophily in terms of function and in terms of tenure affects feedback-seeking in the workplace. Furthermore, we note that having a largely homogeneous feedback-seeking network has detrimental effects on employees employability. 


\section{INTRODUCTION}

Feedback-seeking, individuals' interpersonal search for information to evaluate their behavior (Ashford \& Cummings, 1983; Ashford, 1986), is an important means increasing learning, motivation, and performance within organizations (Van den Bossche, Van Waes, \& Van der Rijt, 2013). For instance, outcomes such as behavioral change and task performance have been found (Anseel, Beatty, Shen, Lievens, \& Sackett, 2013). Recently, it was found that the information obtained by seeking feedback may not only be used for assessing one's capabilities or improving one's effectiveness (Vancouver \& Morrison, 1995), but may also enhance employees' employability (Froehlich, Beausaert, Segers, \& Gerken, 2014; Froehlich, Beausaert, \& Segers, 2014). This study suggest that by informal learning from others, employees are able to enhance their expertise and adaptability and are thereby empowered to fulfill, acquire, or create work for themselves (Van der Heijde \& Van der Heijden, 2006).

The relation between feedback-seeking and employability, however, was researched at a rather broad level. We still do not sufficiently understand how feedback-seeking networks that are beneficial for employability look like. How are they different from other employees' networks? Previous research has established that feedback-seeking relationships do not develop randomly. Instead, homophily - "the tendency of agents to associate disproportionately with those having similar traits" (Golub \& Jackson, 2012, p. 1287) - is an important mechanisms of how networks develop.

In this study, we investigate how homophily affects feedback-seeking in the workplace. Furthermore, we research how the composition of one's feedback-seeking network affects employees employability. For this reason we conduct social network analyses across six samples. In total, we investigated 1,948 feedback-seeking relationships of 107 employees in Austria, India, and the Netherlands. First, we study how homophily affects the composition of feedback-seeking networks at work. Second, we investigate how the composition of these feedback-seeking networks affects employees' employability. 


\section{COMPETENCE-BASED EMPLOYABILITY}

The concept of employability evolved over the last century and was dynamically adapted to the situation on the labor market. As business becomes faster and the rate of innovation accelerates, job descriptions are constantly changing. This makes it increasingly inappropriate to define employability in terms of specific labor market demands. Instead, Van der Heijde and Van der Heijden (2006) suggest a conceptualization of employability that is based on a range of broad competencies. Hence we define individuals' employability as "the continuous fulfilling, acquiring or creating of work through the optimal use of competences" (Van der Heijde \& Van der Heijden, 2006, p. 453). In other words, the possession of certain competencies should allow employees to get, keep, or create work for themselves. In turn, organizations benefit from having an employable workforce (Fleisher, Khapova, \& Jansen, 2014).

To become or stay employable, a package of competencies (Wright \& Snell, 1998), that includes social and adaptive competencies (Fugate, Kinicki, \& Ashforth, 2004; Rodriguez, Patel, Bright, Gregory, \& Gowing, 2002) on top of technical domain knowledge, needs to be considered. Technical and adaptive competencies are especially prevalent in public discourse and academic research (Ashford \& Taylor, 1990; De Cuyper, Bernhard-Oettel, Berntson, De Witte, \& Alarco, 2008; De Vos, De Hauw, \& Van der Heijden, 2011) and often targeted by stereotypes against older employees (Brownell \& Powell, 2013). In addition to occupational expertise (technical knowledge), anticipation and optimization (proactive, self-initiated screening and preparation for potential changes in job and career requirements and conditions), and personal flexibility (reactive adaptation and resilience to change) are vital competencies to stay employable (Van der Heijde \& Van der Heijden, 2006). In other words, we see employees as employable if they not only have relevant technical knowledge, but also are attentive to contextual changes and resilient towards change imposed on them.

\section{ENHANCING EMPLOYABILITY VIA FEEDBACK-SEEKING}

Feedback-seeking is the search for information targeted at evaluating and reflecting upon work processes and the self (Anseel, Lievens, \& Levy, 2007). As feedback-seeking often results in increased employee 
learning and performance, it is an important organizational and individual resource (Ashford \& Cummings, 1985; Van den Bossche et al., 2013). Indeed, feedback-seeking has been related to many positive outcomes such as goal attainment (Ammons, 1956), managerial effectiveness (Ashford \& Tsui, 1991), performance (Kluger \& DeNisi, 1996), a more accurate self-view (Ashford, Blatt, \& VandeWalle, 2003), career success (Cheramie, 2013), and employability (Froehlich, Beausaert, \& Segers, 2014; Van der Heijden, Boon, Van der Klink, \& Meijs, 2009).

Informal learning from others - such as feedback-seeking - has also been studied from a perspective of social network analysis. For instance, Borgatti and Cross (2003) have studied how information-seeking relationships can be characterized. Specifically, they suggest that knowledge about the source's relevant expertise, access to the source, and the costs of seeking information from a particular source are relevant parameters. But also similarity in terms of demographic variables - age, tenure, function, gender (cf. Qin, Muenjohn, \& Chhetri, 2013) - may matter. Indeed, we know from sociology that similarity breeds connection (McPherson, Smith-Lovin, \& Cook, 2001). Personal networks are often rather homogeneous in terms of demographic characteristics, such as age, gender, or occupation (Ibarra, 1992; Louch, 2000). These personal networks are also addressed when seeking for feedback. This suggests that employees hardly ask a random person for feedback (Webster, Freeman, \& Aufdemberg, 2001; Yap \& Harrigan, 2015). Based on this general observation of how personal networks are formed, we infer and hypothesize that employees seek more feedback from colleagues similar to themselves.

While many studies have found positive outcomes of feedbackseeking, Mulder and Ellinger (2013) observe conflicting findings in literature. They partly attribute this to varying conceptualizations of what constitutes good quality feedback. This suggests that the usefulness of the feedback received needs to be considered - not only the frequency of feedbackseeking. This statement is in line with the findings of Van der Rijt et al. (2012), who found that it is much more the quality of the feedback received than the quantity that had an impact on perceived career development of financial experts. Therefore, we also consider the usefulness of the feedback received. Specifically, we posit that employees rate the usefulness of 
feedback received from persons similar to themselves to be higher. This hypothesis is based on observations that trustworthiness matters when it comes to accepting feedback and acting upon it (llgen, Fisher, \& Taylor, 1979) and that homophily largely influences the development of trust (Tang, Gao, Hu, \& Liu, 2013; Winter \& Mitesh, 2013).

Hypothesis 1a: Employees seek more feedback from others that are similar to themselves in terms of age, tenure, function, and gender.

Hypothesis 1b: Employees rate feedback received from others that are similar to themselves in terms of age, tenure, function, and gender as more useful.

What does this mean for employees' employability? Illgen et al. (1979) have noted that it is difficult to separate the effects of feedbackseeking from the source of feedback-seeking. Therefore, the composition of one's feedback-seeking network may have effects on employees' learning. In turn, this may have implications for their employability (Froehlich, Beausaert, \& Segers, 2014).

Previous investigations in the relationship between informal learning from others and employability have mainly produced positive findings. For instance, Van der Heijden et al. (2009) find networking within and outside the own organization to improve all dimensions of employability. Froehlich, et al. (2014) find that feedback-seeking from peers, but not from supervisors, enhances employability. Van der Rijt et al. (2012) report feedback-seeking to affect perceived career development positively among employees in an early career stage. They note that it is especially the usefulness of feedback sought that improves perceived career development - not so the mere frequency of feedback. Positive effects of feedbackseeking are also noted for related concepts such as career success (Cheramie, 2013).

While positive effects of seeking for useful feedback are prevalent in literature, much less focus was put on the role of homophily. We posit, however, that homophily is an important constraint when considering feedback-seeking and its outcomes such as employability. Specifically, we assume that the knowledge within one rather homogeneous group based on age, tenure, function, and gender is more similar than within heterogeneous groups. Therefore, individuals that are heavily influenced by 
homophily constrain themselves to only a limited pool of feedback-seeking opportunities. Therefore, we hypothesize that individuals learn less for their own employability if their feedback-seeking network is characterized by homophily.

Hypothesis 2: Homophilous feedback-seeking networks relate negatively to employability in terms of occupational expertise, anticipation and optimization, and personal flexibility.

\section{Method}

\section{Sample and setting}

We gathered data in six organizations in Austria, India, and the Netherlands (see Table 1). Each of these samples is a complete project team or organizational unit. We studied 107 employees and 1,948 ties; nine employees did not respond (response rate 92\%). Sample A and C are academic units. The employees do teaching and research work. Sample B and $D$ are projects teams of a large IT implementation program. Specifically, the employees work on-site (Sample B) and off-site (Sample D) for the same client to develop and implement an IT system. Sample E includes the leaders of a variety of units in a bank. They are less involved with daily business, but work together as a steering committee. Sample F includes all employees of a small social venture. The employees cover the whole range of activities needed to run the company. 


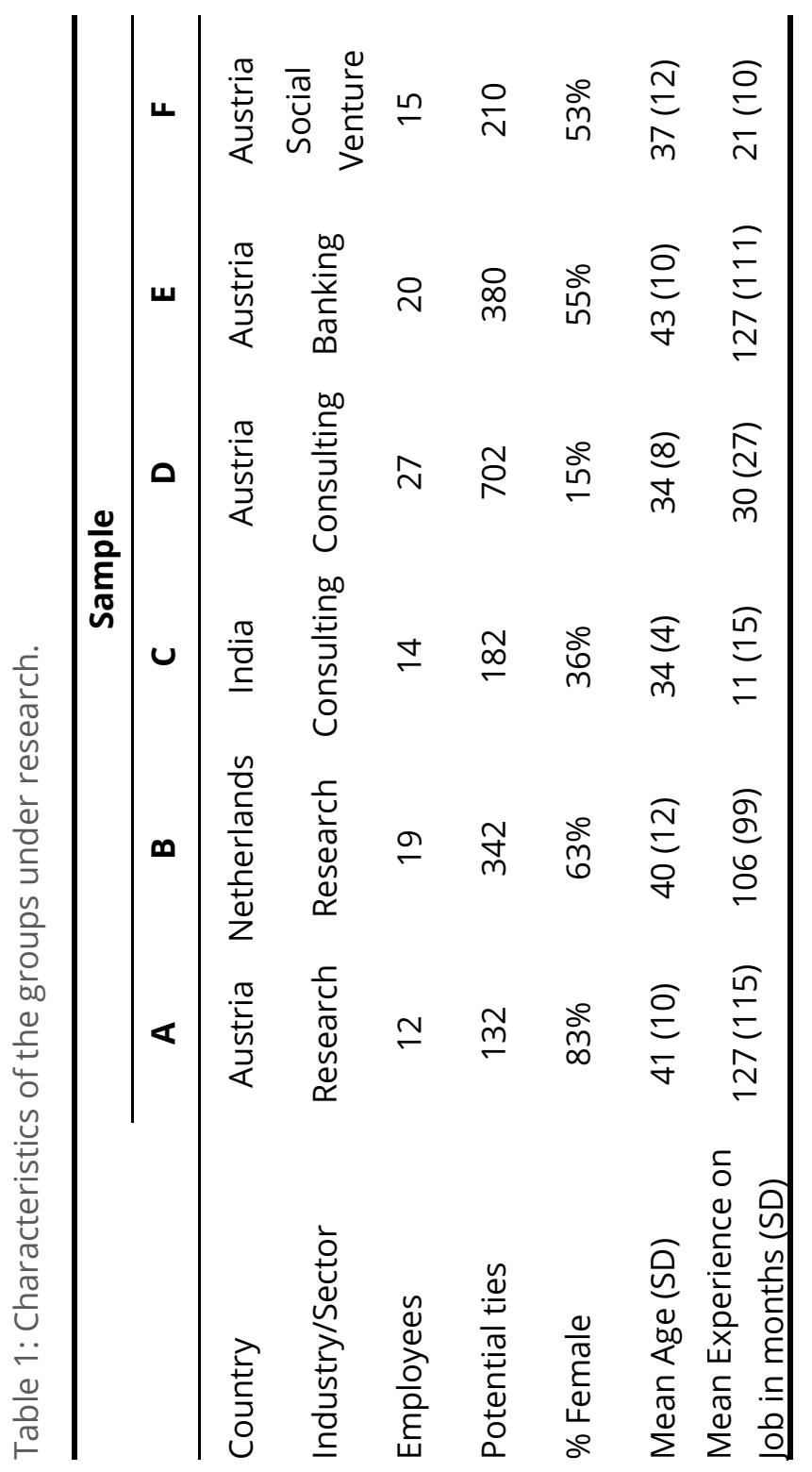




\section{Data collection and measures}

We collected both psychometric and sociometric data. For the sociometric data, we presented each respondent a roster of all employees in the respective work group or project team. We then asked for the frequency of feedback-seeking (from "(almost) never" to "several times a day"). Each person also estimated how often he or she is approached by each other person for feedback. We calculated the mean out of these two values to get an estimate of the frequency of feedback-seeking for each relationship. However, the raters diverged on average only 0.5 points on the rating-scale. Furthermore, we asked for the usefulness of the feedback received from every other person in the network on a 5-point Likert-scale (from "(almost) not useful" to "very useful").

We assessed the similarity of each pair of employees based on the demographic and work-related characteristics of the respondents (age, tenure, function, gender). We evaluated for each tie whether the employees are of similar age (+/- one SD of the group; the SD was chosen to capture the differences in terms of group composition across samples), have similar tenure (+/- one SD of the group), work in similar functions (e.g., administration, marketing, etc. depending on the specificities of each sample), or have the same gender. We then created two adjacency matrices: one that includes the frequencies of feedback-seeking only between similar employees for each respective characteristic ( $\omega$-similar) and one that includes all frequencies of feedback-seeking ( $\omega$-total). Based on these matrices, we calculated the weighted out-degree centrality for all nodes. Weighted out degree centrality denotes the number of outgoing ties each node has multiplied with the respective frequency of interaction. Subsequently, we set the weighted out-degree centrality based on similar persons in relation to the total weighted out-degree centrality of the actor in terms of feedback-seeking frequency for each characteristic.

This can be formalized as:

$$
s_{i}=\frac{\sum_{j}^{N} \omega-\text { similar }_{i j}}{\sum_{j}^{N} \omega-\text { total }_{i j}},
$$

where $i$ is the focal node, $j$ represents all other nodes, $N$ is the total number of nodes, $\omega$ is the weighted adjacency matrix, in which $\omega_{i j}$ represents the weight of the tie between node $i$ and $j$. 
The outcome denotes the percentage of one's sources of feedback similar to the actor, ranging from zero (all sources of feedback are different) to one (all sources of feedback are similar).

We gauged employability using three validated subscales by Van der Heijde and Van der Heijden (2006): occupational expertise (Sample item: "I consider myself competent to engage in in-depth, specialist discussions in my job domain."), anticipation and optimization (Sample item: "I take responsibility for maintaining my labor market value."), and personal flexibility (Sample item: "I adapt to developments within my organization."). Respondents answered on a 5-point Likert-scale ( $1=$ almost never, $5=$ very often). The scales achieved satisfactory Cronbach's alphas ( $a=0.92,0.79$, and 0.70 , respectively).

\section{Analyses}

To test Hypotheses $1 \mathrm{a}$ and $1 \mathrm{~b}$, we used the Multicollinearity Robust Quadratic Assignment Procedure (MRQAP) to estimate multiple regression coefficients in UCINet (Borgatti, Everett, \& Freeman, 2002). MRQAP is often used to analyze autocorrelated structures, such as social network data (Dekker, Krackhardt, \& Snijders, 2003). Put differently, this regression analysis takes into account the dependencies among the employees (Monge \& Contractor, 2003).

After calculating the standardized regression coefficients $(\beta)$, standard errors (SE), and $p$-values for each sample, we performed a metaanalysis to estimate the effects shown in the MRQAP-analyses across all samples. For this purpose, we calculated three statistics: the Q-statistic, the summary effect $\left(\beta_{+}\right)$, and the overall level of significance. For the Q-statistic, which assesses heterogeneity across the samples (Schmidt \& Hunter, 2015), we used the procedure proposed by Krackhardt and Kilduff (1999) that considers issues of autocorrelation:

$$
Q=\sum_{i=1}^{k}\left[\frac{\left(\beta_{i}-\beta_{+}\right)^{2}}{\widehat{\sigma}^{2} \beta_{i}}\right],
$$

where $\beta_{i}$ is the regression coefficient of each sample, $\hat{\sigma}^{2}{ }_{\beta_{i}}$ is the study weight (i.e., its inverse variance), and $k$ is the number of samples. The summary effect size $\beta_{+}$was calculated by: 


$$
\beta_{+}=\frac{\sum_{i=1}^{k} \frac{\beta_{i}}{\hat{\sigma}^{2} \beta_{i}}}{\sum_{i=1}^{k} \frac{1}{\hat{\sigma}^{2} \beta_{i}}} .
$$

The significance of the summary effect size $\beta_{+}$was calculated by using Fisher's (Fisher, 1925) combined probability test:

$$
X^{2}=-2 \sum_{i=1}^{k} \ln p_{i}
$$

where $p_{i}$ is the one-sided $\mathrm{p}$-value of each sample.

We performed multiple regression analyses to test Hypothesis 2, using chronological age, tenure, gender, and organizational background as control variables.

\section{RESULTS}

We hypothesized that employees seek more feedback from colleagues that are similar to themselves in terms of age, tenure, function, and gender. We hypothesized that employees seek more feedback from colleagues that are similar to themselves in terms of age, tenure, function, and gender. Table 2 shows the results of the MRQAP. We find evidence that employees seek feedback more often from colleagues that work in the same function (five samples; from $\beta=0.23, p<0.05$ to $\beta=0.39, p<0.01$ ) and have the same gender (sample $B$ : $\beta=0.17, p<0.05$ ). Conversely, employees addressed colleagues of a different age more readily in sample $F(\beta=-0.14$, $p<0.10$ ). For colleagues with a similar tenure we found both positive (sample $D: \beta=0.08, p<0.05$ ) and negative (sample $C: \beta=-0.15, p<0.10$ ) relationships with feedback-seeking frequency. The independent variables explained a variance in feedback-seeking frequency of up to $20 \%$ (in sample A). 
Table 2: Standardized results of the Matrix Multiple Regression via DoubleDekker Semi-Partialling analyses with feedback-seeking frequency as dependent variable.

\begin{tabular}{|c|c|c|c|c|c|c|}
\hline & \multicolumn{6}{|c|}{ Sample } \\
\hline & A & B & C & D & $\mathbf{E}$ & $\mathbf{F}$ \\
\hline $\mathrm{R}^{2}$ & $.20 * \star$ & $.16 * \star$ & $.07 * \star$ & $.13 * \star$ & .01 & $.17^{* \star}$ \\
\hline Similar Age & -.07 & .04 & -.01 & -.01 & -.02 & .14 \\
\hline Similar Tenure & -.02 & .03 & -.15 & $.08 *$ & .01 & .02 \\
\hline Similar Function & $.39 * *$ & $.37 * \star$ & $.23^{*}$ & $.35 * \star$ & .06 & $.37 * *$ \\
\hline Same Gender & -.26 & $.17^{* \star}$ & -.05 & -.08 & -.05 & -.01 \\
\hline
\end{tabular}

Table 3 shows a similar pattern for the effects on the perceived usefulness of feedback. Employees perceive feedback more useful from colleagues that work in the same function (five samples; from $\beta=0.17, p<$ 0.05 to $\beta=0.45, p<0.01$ ) and that have a similar tenure (sample $D$ : $\beta=0.19$, $p<0.05$; sample $E$ : $\beta=0.18, p<0.10$ ). We found mixed results for colleagues of a similar age (sample F: $\beta=0.17, p<0.05$; sample $D$ : $\beta=-0.13, p<0.10$ ) and the same gender (sample $B$ : $\beta=0.16, p<0.01$; sample $D$ : $\beta=-0.16, p<$ $0.10)$. The independent variables explained a variance in perceived usefulness of feedback of up to $23 \%$ (in sample A).

Table 3: Standardized results of the Matrix Multiple Regression via DoubleDekker Semi-Partialling analyses with perceived usefulness of feedback as dependent variable.

\begin{tabular}{|c|c|c|c|c|c|c|}
\hline & \multicolumn{6}{|c|}{ Sample } \\
\hline & A & B & $\mathrm{C}$ & D & $E$ & $\mathbf{F}$ \\
\hline $\mathrm{R}^{2}$ & $.23 * *$ & $.10 * \star$ & $.05 *$ & $.09 * \star$ & .03 & $.14 * \star$ \\
\hline Similar Age & -.14 & .06 & -.02 & -.13 & -.10 & $.17 *$ \\
\hline Similar Tenure & -.03 & .11 & -.15 & $.19 *$ & .18 & .02 \\
\hline Similar Function & $.45^{\star *}$ & $.25 * \star$ & $.17^{*}$ & $.19 * *$ & -.01 & $.32 * *$ \\
\hline Same Gender & -.22 & $.16^{* \star}$ & -.09 & -.16 & -.05 & .01 \\
\hline
\end{tabular}

* $p<.05 ; * * p<.01$. 
Table 4 shows the results of the meta-analysis. The Q-statistics show that heterogeneity was found only for the relationship between same function and feedback-seeking frequency $(Q=21.41, p<0.01)$. We found a strong and significant summary effect on feedback-seeking frequency of same function $\left(\beta_{+}=0.31, p<0.01\right)$. This means that across samples, employees were more likely to seek feedback from colleagues that work in a similar function, which indicates homophily. Therefore, Hypothesis $1 \mathrm{a}$ is only partially supported.

For the MRQAP analyses of the perceived usefulness of the feedback received, the effect sizes were homogeneous across all independent variables. We found a strong summary effect of same function $\left(\beta_{+}=0.19, p<\right.$ $0.01)$ and a small effect for same tenure $\left(\beta_{+}=0.05, p<0.10\right)$. This supports Hypothesis $1 \mathrm{~b}$ for experience and function.

Table 4: Combined results of the Matrix Multiple Regression via DoubleDekker Semi-Partialling analyses $(\mathrm{df}=5)$.

\begin{tabular}{lcccc}
\hline & \multicolumn{2}{c}{ Frequency } & \multicolumn{2}{c}{ Usefulness } \\
& $\mathbf{Q}$ & $\boldsymbol{\beta}_{+}$ & $\mathbf{Q}$ & $\boldsymbol{\beta}_{+}$ \\
\hline Similar Age & 0.51 & .00 & 0.67 & -.02 \\
Similar Tenure & 1.28 & .04 & 0.48 & .05 \\
Similar Function & $21.41^{\star \star}$ & $.31^{\star \star}$ & 3.89 & $.19^{\star \star}$ \\
Same Gender & 1.94 & -.02 & 0.86 & -.03 \\
\hline$\star p<.05 ; * \star p<.01$. & & & &
\end{tabular}

In the linear multiple regression analyses (Table 5), we find that homophily in terms of function relates negatively to anticipation and optimization $(\beta=-1.11, p<0.01)$ and personal flexibility $(\beta=-0.99, p<0.05)$. Similarly, homophily in terms of age relates negatively to occupational expertise $(\beta=-0.74, p<0.05)$. These findings suggest that feedback-seeking networks largely composed out of people of similar age and that work in a similar function relative to the feedback seeker are not helpful for one's employability. Therefore, Hypothesis 2 is partially confirmed. Conversely, 
homophily in terms of tenure and gender relate positively to personal flexibility $(\beta=0.75, p<0.05)$ and occupational expertise $(\beta=0.74, p<0.05)$, respectively. As concerns the control variables, we note negative effects of chronological age on occupational expertise $(\beta=-0.03, p<0.05)$ and differences between the participating organizations. In total, the model explains a fifth to a quarter of the employability scales $\left(R^{2}=0.17\right.$ to 0.27$)$.

Table 5: Unstandardized results of the linear multiple regression analyses.

\begin{tabular}{|c|c|c|c|}
\hline & $\begin{array}{l}\text { Occupational } \\
\text { Expertise }\end{array}$ & $\begin{array}{c}\text { Anticipation \& } \\
\text { Optimization }\end{array}$ & $\begin{array}{l}\text { Personal } \\
\text { Flexibility }\end{array}$ \\
\hline $\mathrm{R}^{2}$ & $.24^{\star \star}$ & .17 & $.27 * \star$ \\
\hline Chronological Age & $-.03 *$ & -.02 & .00 \\
\hline Tenure & .02 & .00 & .02 \\
\hline Gender & .13 & -.17 & -.10 \\
\hline Sector 2 & .23 & .34 & $.54^{* *}$ \\
\hline Sector 3 & $.66^{* \star}$ & .16 & .35 \\
\hline Sector 4 & .60 & .61 & $1.35^{\star \star}$ \\
\hline \% similar Age & $-.74^{*}$ & -.06 & -.01 \\
\hline \% similar Tenure & -.23 & .51 & $.75^{\star}$ \\
\hline$\%$ similar Function & -.64 & $-1.11 * *$ & $-.99 *$ \\
\hline \% same Gender & $.74 *$ & .18 & .08 \\
\hline
\end{tabular}

* $p<.05 ; * * p<.01$

\section{Discussion}

We set out to investigate how homophily relates to feedback-seeking in the workplace and employees' employability. We hypothesized that employees tend to seek feedback from colleagues that are similar to themselves. Additionally, we proposed that the feedback received from similar sources is perceived to be more useful. The meta-analysis across six organization shows that employees go to colleagues that are similar to themselves for feedback more often and that the feedback received from these sources is perceived as more useful. In addition, we have found that similarity in terms of tenure relates positively to the perceived usefulness of the feedback received. These relationships can be explained by the principle 
of homophily - the tendency of people to favor similar others (McPherson et al., 2001). At the same time, we note that having a largely homogeneous feedback-seeking network may have detrimental effects on one's employability. Specifically, we find negative effects of a homogeneous network in terms of function. While homophily in terms of function hinders anticipation and optimization and personal flexibility, there is no effect on occupational expertise. One reason for this might be that colleagues outside the own function have access to different information. Therefore, a feedback-seeking network that consists mainly of colleagues in the same function has limited potential to access information outside the main domain of work. This limits one's potential to become aware of trends in this area. But when it comes to the technical expertise needed for the tasks at hand, this information is not very relevant. Accordingly, we do not find a negative effect of homophily in terms of function on occupational expertise. Interestingly, the sociometric data reveals that the employees themselves judge the feedback received from their colleagues in the same function as more useful. This contradiction may result from the definition of usefulness the respondents had in mind when answering the questionnaire. For instance, usefulness may be perceived to be high when the feedback helps to resolve an immediate issue. Taking the long term perspective and relating the usefulness to the impact on one's employability, which also includes other competences such as flexibility, may be less common.

Furthermore, we find a negative relationship between a homogeneous feedback-seeking network in terms of age and occupational expertise. To the best of our knowledge, this has not been investigated before. However, one possible reason for this is that the knowledge and skills are different, but compatible across age groups. For instance, younger employees may contribute important knowledge of how to use IT more efficiently, while older employees may give helpful advice for social relationships and general conduct of work. Eventually, all of these competences are needed to remain employable. Therefore, seeking feedback also from colleagues of other age groups is beneficial.

The findings show a positive relationship of homogeneous feedbackseeking networks in terms of tenure and personal flexibility. This indicates that employees that predominantly contact colleagues with a similar 
amount of experience of work feel better prepared to adapt to changes in their job. One explanation for this may be that people of similar tenure are in comparable career situations. For instance, two newly appointed managers may learn a lot from giving each other feedback about how to adapt to the new tasks assigned to them. Feedback-seeking from colleagues that have no management experience or that are in much senior positions may not be that applicable. This is also reflected by the sociometric data, where we find that feedback received from colleagues with similar tenure is perceived as more useful.

In sum, while previous research has investigated the effects of feedback-seeking on employability (e.g., Froehlich, Beausaert, Segers, et al., 2014), we extend the body of literature by considering the sources of feedback-seeking and by considering the composition of employees' feedback-seeking networks. The findings suggest that employees are more likely to ask colleagues similar to themselves for feedback. However, having a highly homogeneous feedback-seeking network is not always beneficial for one's employability. Practitioners may consider intervening into the network to facilitate ties between different people. For instance, this may include assigning tasks to pairs of previously unrelated colleagues with different backgrounds or a general awareness training about one's social network in the workplace.

\section{LIMITATIONS AND DIRECTIONS FOR FUTURE RESEARCH}

The meta-analytic strategy applied in this research allowed to find effects that are significant across the samples under study. The MRQAP analyses of individual samples (cf. Tables 2 and 3), however, show varying patterns of effects in the samples. This exploratory research cannot fully explain why these differences exist. Specifically, while there are many potential differences between the groups - for instance, in terms of climate concerning diversity (Chrobot-Mason \& Aramovich, 2013) or group composition - our research does not capture all of these variables. Interestingly, while our model explained a significant part of the variance in the MRQAP analyses in five samples, no significant relationships were found for sample E. One apparent difference between sample $E$ and the other samples is the content of work: Sample $E$ is a steering committee with its 
members spread across organizational units. Consequently, their work is less focused on technical details, but more on coordinating and managing. Future research may consider the different tasks and work goals.

Social network analysis demands that boundaries are set that define who is in the network and who is not (Borgatti, Everett, \& Johnson, 2013). We based our decision on the assumption that the most relevant sources for feedback are available in the same organizational unit. The strong effects of homogeneity in terms of function on the frequency and perceived usefulness of feedback-seeking support this assumption. However, informal learning from others - such as feedback-seeking - may cross formal organizational boundaries. For example, acquaintances that work at different departments or organizations, members of the same sports club, or family members may also be good sources for feedback. Future research may also make use of approaches that are more liberal in that respect, like ego-social network analyses or qualitative methods.

The measurement of constructs used presents another challenge. The self-reported scores of feedback-seeking and employability may raise concerns about common method variance (Podsakoff \& Organ, 1986). However, self-appraised employability scores are well supported by theory and empirical evidence (Dries, Forrier, De Vos, \& Pepermans, 2014; Kinnunen, Mäkikangas, Mauno, Siponen, \& Nätti, 2011). Also, both the source and the target were asked about the frequency about the feedbackseeking relationship. Nevertheless, future research may use different methods and different sources. After all, previous research found employees to rate themselves higher than their employers (Van der Heijde \& Van der Heijden, 2006) and higher than their labor market success would suggest (Patrickson \& Ranzijn, 2003).

\section{CONCLUSION}

The research highlights that the way feedback networks develop may not be the best one to enhance the workforce's employability. Specifically, while there is a tendency of employees to ask colleagues similar to themselves, this does not always translate into receiving the most useful feedback. We challenge human resource managers to take a more active role in designing these feedback seeking activities and relationship. 


\section{REFERENCES}

Ammons, R. B. (1956). Effects of Knowledge of Performance: A Survey and Tentative Theoretical Formulation. Journal of General Psychology, 54(2), 279-299. doi:10.1080/00221309.1956.9920284

Anseel, F., Beatty, A. S., Shen, W., Lievens, F., \& Sackett, P. R. (2013). How Are We Doing After 30 Years? A Meta-Analytic Review of the Antecedents and Outcomes of Feedback-Seeking Behavior. Journal of Management, 41(1), 318-348. doi:10.1177/0149206313484521

Anseel, F., Lievens, F., \& Levy, P. E. (2007). A Self-motives Perspective on Feedback-seeking Behavior: Linking Organizational Behavior and Social Psychology Research. International Journal of Management Reviews, 9(3), 211-236. doi:10.1111/j.1468-2370.2007.00210.x

Ashford, S. J. (1986). Feedback-Seeking in Individual Adaptation: A Resource Perspective. Academy of Management Journal, 29(3), 465-487.

Ashford, S. J., Blatt, R., \& VandeWalle, D. (2003). Reflections on the Looking Glass: A Review of Research on Feedback-Seeking Behavior in Organizations. Journal of Management, 29(6), 773-799. doi:10.1016/S0149-2063(03)00079-5

Ashford, S. J., \& Cummings, L. L. (1983). Feedback as an Individual Resource: Personal Strategies of Creating Information. Organizational Behavior and Human Performance, 32, 370-398.

Ashford, S. J., \& Cummings, L. L. (1985). Proactive feedback seeking: The instrumental use of the information environment. Journal of Occupational Psychology, 58, 67-79.

Ashford, S. J., \& Taylor, M. S. (1990). Adaptationto work transitions: An integrative approach. In G. R. Ferris \& K. M. Rowland (Eds.), Research in personnel and human resource management (Vol. 8, pp. 1-39). Greenwich, CT: JAI Press.

Ashford, S. J., \& Tsui, A. S. (1991). Self-Regulation for Managerial Effectiveness: The Role of Active Feedback Seeking. Academy of Management Journal, 34(2), 251-280.

Borgatti, S. P., \& Cross, R. (2003). A Relational View of Information Seeking and Learning in Social Networks. Management Science, 49(4), 432-445. 
Borgatti, S. P., Everett, M. G., \& Freeman, L. C. (2002). UCINet for Windows: Software for Social Network Analysis. Harvard, MA: Analytic Technologies.

Borgatti, S. P., Everett, M. G., \& Johnson, J. C. (2013). Analyzing Social Networks. London: Sage.

Brownell, P., \& Powell, M. S. W. (2013). Definitions and Theoretical Models for Understanding Ageism and Abuse in the Workplace. In P. Brownell \& J. J. Kelly (Eds.), Ageism and Mistreatment of Older Workers: Current Reality, Future Solutions (pp. 17-28). New York: Springer.

Cheramie, R. (2013). An examination of feedback-seeking behaviors, the feedback source and career success. Career Development International, 18(7), 712-731. doi:10.1108/CDI-05-2013-0070

Chrobot-Mason, D., \& Aramovich, N. P. (2013). The Psychological Benefits of Creating an Affirming Climate for Workplace Diversity. Group \& Organization Management, 38(6), 659-689. doi:10.1177/1059601113509835

De Cuyper, N., Bernhard-Oettel, C., Berntson, E., De Witte, H., \& Alarco, B. (2008). Employability and Employees' Well-Being: Mediation by Job Insecurity. Applied Psychology, 57(3), 488-509.

De Vos, A., De Hauw, S., \& Van der Heijden, B. I. J. M. (2011). Competency development and career success: The mediating role of employability. Journal of Vocational Behavior, 79(2), 438-447. doi:10.1016/j.jvb.2011.05.010

Dekker, D., Krackhardt, D., \& Snijders, T. A. B. (2003). Multicollinearity Robust QAP for Multipe-Regression, 1-5.

Dries, N., Forrier, A., De Vos, A., \& Pepermans, R. (2014). Self-perceived employability, organization-rated potential, and the psychological contract. Journal of Managerial Psychology, 29(5), 565-581. doi:10.1108/JMP-04-2013-0109

Fisher, R. A. (1925). Statistical methods for research workers. Biological monographs and manuals.

Fleisher, C., Khapova, S. N., \& Jansen, P. G. W. (2014). Effects of employees' career competencies development on their organizations. Career 
Development International, 19(6), 700-717. doi:10.1108/CDI-12-20130150

Froehlich, D. E., Beausaert, S. A. J., \& Segers, M. S. R. (2014). Age, employability and the role of learning activities and their motivational antecedents: a conceptual model. International Journal of Human Resource Management, 1-15. doi:10.1080/09585192.2014.971846

Froehlich, D. E., Beausaert, S. A. J., Segers, M. S. R., \& Gerken, M. (2014). Learning to Stay Employable. Career Development International, 19(5), 508-525. doi:10.1108/CDI-11-2013-0139

Fugate, M., Kinicki, A. J., \& Ashforth, B. E. (2004). Employability: A psychosocial construct, its dimensions, and applications. Journal of Vocational Behavior, 65(1), 14-38. doi:10.1016/j.jvb.2003.10.005

Golub, B., \& Jackson, M. O. (2012). How Homophily Affects the Speed of Learning and Best-Response Dynamics. Quarterly Journal of Economics, 127(3), 1287-1338. doi:10.1093/qje/qjs021

Ibarra, H. (1992). Homophily and Differential Returns: Sex Differences in Network Structure and Access in an Advertising Firm. Administrative Science Quarterly, 37(3), 422-447.

Ilgen, D. R., Fisher, C. D., \& Taylor, M. S. (1979). Consequences of individual feedback on behavior in organizations. Journal of Applied Psychology, 64(4), 349-371. doi:10.1037/0021-9010.64.4.349

Kinnunen, U., Mäkikangas, A., Mauno, S., Siponen, K., \& Nätti, J. (2011). Perceived employability: Investigating outcomes among involuntary and voluntary temporary employees compared to permanent employees. Career Development International, 16(2), 140-160. doi:10.1108/13620431111115604

Kluger, A. N., \& DeNisi, A. (1996). The Effects of feedback intervention on performance: A historical review, a meta-analysis, and a preliminary feedback intervention theory. Psychological Bulletin, 119(2), 254-284. doi:10.1037/0033-2909.119.2.254

Krackhardt, D., \& Kilduff, M. (1999). Whether Close or Far: Social Distance Effects on Perceived Balance in Friendship Networks. Journal of Personality and Social Psychology, 76(5), 770-782. 
Louch, H. (2000). Personal network integration: transitivity an homophily in strong-tie relations. Social Networks, 22, 45-64.

McPherson, M., Smith-Lovin, L., \& Cook, J. M. (2001). Birds of a Feather: Homophily in Social Networks. Annual Review of Sociology, 27, 415-444.

Monge, P. R., \& Contractor, N. S. (2003). Theories of Communication Networks. New York City, NY: Oxford University Press.

Mulder, R. H., \& Ellinger, A. D. (2013). Perceptions of quality of feedback in organizations: Characteristics, determinants, outcomes of feedback, and possibilities for improvement: introduction to a special issue. European Journal of Training and Development, 37(1), 4-23. doi:10.1108/03090591311293266

Patrickson, M., \& Ranzijn, R. (2003). Employability of Older Workers. Equal Opportunities International, 22(5), 50-63. doi:10.1108/02610150310787496

Podsakoff, P. M., \& Organ, D. W. (1986). Self-Reports in Organizational Research: Problems and Prospects. Journal of Management, 12(4), 531 544. doi:10.1177/014920638601200408

Qin, J., Muenjohn, N., \& Chhetri, P. (2013). A Review of Diversity Conceptualizations: Variety, Trends, and a Framework. Human Resource Development Review, 13(2), 133-157. doi:10.1177/1534484313492329

Rodriguez, D., Patel, R., Bright, A., Gregory, D., \& Gowing, M. K. (2002). Developing competency models to promote integrated human resource practices. Human Resource Management, 41(3), 309-324. doi:10.1002/hrm.10043

Schmidt, F. L., \& Hunter, J. E. (2015). Methods of Meta-Analysis (3rd ed.). Los Angeles, CA: Sage.

Tang, J., Gao, H., Hu, X., \& Liu, H. (2013). Exploiting homophily effect for trust prediction. Proceedings of the sixth ACM international conference on Web search and data mining - WSDM '13 (p. 53). New York, New York, USA: ACM Press. doi:10.1145/2433396.2433405

Van den Bossche, P., Van Waes, S., \& Van der Rijt, J. (2013). Feedback, Development, and Social Networks. In K. Kraiger, J. Passmore, N. R. dos Santos, \& S. Malvezzi (Eds.), The Wiley Blackwell Handbook of the 
Psychology of Training, Development, and Performance Improvement. Wiley.

Van der Heijde, C. M., \& Van der Heijden, B. I. J. M. (2006). A competencebased and multidimensional operationalization and measurement of employability. Human Resource Management, 45(3), 449-476. doi:10.1002/hrm.20119

Van der Heijden, B. I. J. M., Boon, J., Van der Klink, M. R., \& Meijs, E. (2009). Employability Enhancement through Formal and Informal Learning: An Empirical Study among Dutch Non-Academic University Staff Members. International Journal of Training and Development, 13(1), 19-37. doi:10.1111/j.1468-2419.2008.00313.x

Van der Rijt, J., Van den Bossche, P., Van de Wiel, M. W. J., Segers, M. S. R., \& Gijselaers, W. H. (2012). The role of individual and organizational characteristics in feedback-seeking behaviour in the initial career stage. Human Resource Development International, 15(3), 283-301. doi:10.1080/13678868.2012.689216

Vancouver, J. B., \& Morrison, E. W. (1995). Feedback Inquiry: The Effect of Source Attributes and Individual Differences. Organizational Behavior \& Human Decision Processes. doi:http://dx.doi.org/10.1006/obhd.1995.1050

Webster, C. M., Freeman, L. C., \& Aufdemberg, C. G. (2001). The Impact of Social Context on Interaction Patterns. Journal of Social Structure, 2(1).

Winter, F., \& Mitesh, K. (2013). You Are Who Your Friends Are: An Experiment on Trust and Homophily in Friendship Networks. Jena Economic Research Papers, 44.

Wright, P. M., \& Snell, S. A. (1998). Toward a Unifying Framework for Exploring Fit and Flexibility in Strategic Human Resource Management. Academy of Management Review, 23(4), 756-772.

Yap, J., \& Harrigan, N. (2015). Why does everybody hate me? Balance, status, and homophily: The triumvirate of signed tie formation. Social Networks, 40, 103-122. doi:10.1016/j.socnet.2014.08.002 


\section{CHAPTER 7}

General Discussion and Directions for Future Research 
170 | General Discussion 


\section{GeNerAL DisCussion}

As the population ages and governments revise policies to encourage longer working lives (Bal, Kooij, \& Rousseau, 2015a; Billett, 2011; Department for Business Innovation and Skills, 2011), the workforce in organizations is becoming older (Anderson, 2013; Loch, Sting, Bauer, \& Mauermann, 2010). At the same time, due to increasing global competition and the accelerated rate of innovation, the workplace is becoming more and more dynamic. Given those facts, how does the aging workforce fit into the picture of a dynamic business environment? Common stereotypes often cast doubt on the ability of older employees to learn and adapt to changes. This questions older employees' employability, their competence to continuously fulfill and acquire work for themselves (Van der Heijde \& Van der Heijden, 2006).

In this dissertation, we chose a learning perspective to investigate the relationship between chronological age and employability. In Chapter 2 , we proposed a model that explains the relationship between chronological age and employability via two groups of mediators: motivation and learning activities (see Figure 1).

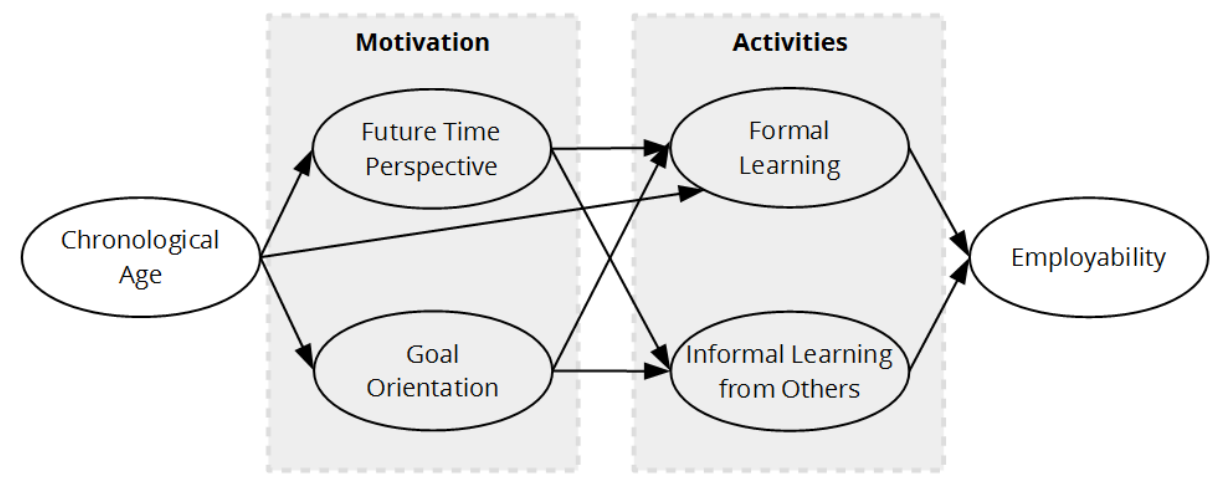

Figure 1: Research model of this dissertation.

We argued that relating chronological age directly to employability, which is common in workplace stereotypes, underestimates the complexity of the relationship. First, this is because chronological age is composed of different effects, such as effects of the time or period, which cannot be 
disentangled from each other (Hall, Mairesse, \& Turner, 2007). Second, older workers are a very heterogeneous group (Bal, Kooij, \& Rousseau, 2015b; Staudinger \& Bowen, 2011), which often makes it difficult to generalize findings over the entire population of older employees. Third, individuals cannot change their chronological age. Despite that, human resource managers need to find drivers of employability upon which they can act. Therefore, in this dissertation, we studied the role of motivation and learning activities.

We proposed that employees' motivation plays a key role, as previous research suggests that the motivation to develop one's competences changes with age (Elliot \& McGregor, 2001; Lang \& Carstensen, 2002). We focused on two theories that have been applied in the context of an aging workforce: socioemotional selectivity theory (Carstensen, 2006) and goal orientation theory (Elliot \& McGregor, 2001). First, socioemotional selectivity theory argues that people's goals change as they age. Older people focus more on achieving emotional balance than on developing their competences (Lang \& Carstensen, 2002). In line with this theory, we argued that a focus on opportunities in future life enhances employability, while a focus on the limitations is negatively related to employability. Second, goal orientation theory proposes that individuals define, approach, and respond to achievement situations differently depending on a set of beliefs and attributions concerning competence (Brett \& VandeWalle, 1999; Van Dierendonck \& Van der Gaast, 2013). Previous work suggested that this set of beliefs and attributions changes with age: older people are more oriented towards maintaining their status (Ebner, Freund, \& Baltes, 2006; Ogilvie, Rose, \& Heppen, 2010) and show a distinct decrease in growth motives (Kooij, De Lange, Jansen, Kanfer, \& Dikkers, 2011).

Motivation alone, however, is hardly enough to develop competences and remain employable. Therefore, we also took a learning perspective in this dissertation. We hypothesized that motivated employees are more eager to undertake formal and informal learning activities, which enhances their employability. Formal learning consists of all the learning inside structures created for that purpose, such as seminars, lectures, or workshops (CEDEFOP, 2008). Informal learning is less pre-structured, more controlled by the learner, embedded in daily working activities, and may 
happen unconsciously (cf. Livingstone, 2001; Marsick \& Watkins, 2001). This includes, for instance, learning by doing the job, exchanging information and feedback with others, or seeking help. Specifically, in this dissertation, we focused on informal learning from others in terms of proactive information-, feedback-, and help-seeking. We chose this approach because previous research has indicated that this social aspect of informal learning is highly important (Bamberger, 2009; Eraut, 2007).

We tested this model in four empirical studies and each study highlighted a different part of the model. In sum, the empirical chapters showed that the model explains how chronological age, motivation, and learning activities relate to employability. We learned three important points regarding employability from the considered empirical studies:

- learning activities matter,

- motivation matters, and

- chronological age affects employability indirectly.

\section{Learning activities matter}

We found evidence for the hypothesized positive relationship between learning activities and employability in Chapters 3 and 5. In Chapter 3, we examined the effects of chronological age and formal and informal learning activities on employability. In our sample of 780 employees of three Dutch and Austrian organizations, we found that both formal learning and informal learning from others increase employees' employability. However, each type of learning contributes to different components of employability. This study contributed further evidence for the relationships of chronological age and formal and informal learning on employability. It extended previous literature by suggesting that the different forms of learning - formal learning, information-seeking, feedbackseeking, and help-seeking - have different effects on the dimensions of employability. Therefore, a variety of learning activities is helpful in developing all the competences needed to remain employable. In Chapter 5, we found positive relationships between informal learning from others and four dimensions of employability: anticipation and optimization, personal flexibility, corporate sense, and balance. These findings are in line with previous research (Froehlich, Beausaert, Segers, \& Gerken, 2014; Van der 
Heijden, Boon, Van der Klink, \& Meijs, 2009; Van der Klink, Van der Heijden, Boon, \& Williams van Rooij, 2014).

These findings suggest that learning activities are effective means of developing the competences to fulfill, acquire, or create work, which is in line with our propositions (see Chapter 2) and earlier research that has found positive relationships between learning activities and employability (De Vos, De Hauw, \& Van der Heijden, 2011; Groot \& Van den Brink, 2000; Van der Heijden et al., 2009). Our finding that formal learning affected only anticipation and optimization, whereas informal learning from others also stimulated occupational expertise and personal flexibility, adds an important nuance that suggests two things. First, employees' social networks at work affect their employability. By asking for feedback, help, and information, employees connect to important sources for learning and for shaping their expertise and flexibility. Second, learning in more formal settings, such as seminars or lectures, may be especially useful for learning about new developments and trends. Subsequently, this information will help employees adapt to the requirements of the future labor market. In sum, this suggests that both forms of learning are compatible with each other when it comes to developing employability

In Chapter 6, we focused on the aspect of learning from others using social network analysis. This approach allowed us to investigate the nuances of informal learning from others in the workplace. Previous research has established that informal learning from others enhances employees' employability. This study extended that strand of research by investigating how the demographic attributes of feedback sources make a difference. Specifically, we tested whether homophily, the tendency of employees to connect with similar co-workers, impacts the feedback-seeking network in an organization. In this analysis of 1,948 feedback-seeking relationships of 107 employees in Austria, India, and the Netherlands, we found that in some organizations, people seek more feedback from colleagues that are similar in terms of function, tenure, chronological age, or gender. This is in line with previous research arguing that homophily structures network ties (e.g., Apfelbaum, Phillips, \& Richeson, 2014; McPherson, Smith-Lovin, \& Cook, 2001). At the same time, however, this structuring has negative effects on employability if homophily leads to a somewhat homogeneous feedback- 
seeking network at work. This can be explained by the limited scope of knowledge and information that circulates in rather homogeneous networks. Also, having ties to other groups of people potentially enriches the perspectives that can be accessed. This phenomenon was described in more detail by Granovetter's (1973) concept of "weak ties". It implies that maintaining relationships outside the core of one's work may also be beneficial for one's employability. At the same time, it stresses the need to be conscious of one's feedback sources. Hearing homogeneous feedback from a homogeneous group of people is not only limiting, but also a potential source of bias. For example, homogeneity within a network has been found to be an antecedent to groupthink (Janis, 1982; Park, 1990). The findings of the social network analyses suggest that the formation of ties between dissimilar employees may require support or encouragement. For instance, this may include assigning tasks to pairs of previously unrelated colleagues with different backgrounds or awareness training about one's social network within the workplace.

\section{Motivation matters}

Having found positive effects from activities of formal learning and informal learning from others, the question remained of what triggered these learning activities. Why did some employees actively pursue learning activities while others did not? We took a motivational perspective to study age-related antecedents of employability to better understand the relationship between chronological age and employability. Specifically, we investigated the relationships of future time perspective (Carstensen, 2006) and goal orientation (Elliot \& McGregor, 2001) with employability (Van der Heijde \& Van der Heijden, 2006). In Chapter 4, we conducted quantitative, cross-sectional survey research among 282 employees of three Dutch and Austrian organizations. Using structural equation modeling, we found that future time perspective and goal orientation strongly relate to employability. Additionally, chronological age affects employability indirectly via perceived remaining opportunities. This study contributes evidence for the relationships of chronological age, future time perspective, and goal orientation with employability. Specifically, the findings advise human resource managers to promote mastery and performance approach 
orientations and an extensive future time perspective. In addition, the study expands previous knowledge by suggesting a mechanism by which chronological age affects employability indirectly. Instead of focusing on a variable that cannot be influenced, chronological age, our research hints at the potential of targeting employees' motivation.

These effects of opportunity focus, mastery approach orientation, and performance approach orientation are in line with our hypotheses. Specifically, we argued that having an opportunity focus increases the value of undertaking learning activities (Lang \& Carstensen, 2002). For instance, if an employee sees the potential for being promoted, she may feel more motivated to undertake learning activities to meet the requirements to be promoted. Contrarily, if the expectation is that she will not be promoted in her remaining working life, no matter how qualified she is, there is less value ascribed to undertaking learning activities. Consequently, the employee might focus less on learning. A similar rationale may be applied to the effects of mastery and performance goal orientation. Here, the valence employees ascribe to competence matters (Janssen \& Prins, 2007). Employees that aim to develop their competences (mastery approach) or, to a lesser extent, that want to demonstrate their competence to others (performance approach), are interested in engaging in learning activities.

In Chapter 5, we have found evidence that an opportunity focus does stimulate informal learning from others among the 167 Austrian consultants under consideration. We therefore extend the body of knowledge by finding a positive indirect relationship between opportunity focus and employability via informal learning from others. This finding means that employees with an opportunity focus are more likely to proactively seek feedback and help from others in the workplace. This, in turn, helps them to develop the necessary competences to stay employable. Furthermore, this study creates a link between the literature about older employees' motivation and future time perspective (De Lange, Bal, Van der Heijden, De Jong, \& Schaufeli, 2011; Gegenfurtner \& Vauras, 2012; Kooij, Bal, \& Kanfer, 2014) and adds insight about learning for employability (e.g., Van der Heijden et al., 2009), which was previously missing. This study complements another ongoing research project investigating the 
relationship between goal orientation, informal learning from others, and employability (Aasma, Froehlich, \& Beausaert, manuscript in preparation).

Managers who are concerned about their (older) employees' motivation may adopt a variety of strategies to support opportunity focus and approach orientations. Measures may include, for example, clarifying learning activities' utility ex-ante (Simons, Vansteenkiste, Lens, \& Lacante, 2004), making the connection between work-related learning and personal goals more explicit (Phalet, Andriessen, \& Lens, 2004), facilitating long-term planning and personal development plans (Beausaert, Segers, Van der Rijt, \& Gijselaers, 2011; Gellert, Ziegelmann, Lippke, \& Schwarzer, 2012), offering goal orientation training (Noordzij, Van Hooft, Van Mierlo, Van Dam, \& Born, 2013), evaluating employees on their progress and improvement (Ames, 1992), or creating more tolerance towards errors and accepting them as a part of the learning process (Van Yperen \& Orehek, 2013).

\section{Chronological age affects employability indirectly}

The results of the studies did not show consistent effects of chronological age on the dimensions of employability. However, the mediation analyses showed indirect effects of chronological age on employability via formal learning (Chapter 3) and via opportunity focus (Chapter 4). This is because chronological age relates negatively to formal learning and opportunity focus, which would otherwise have positive effects on employability. The negative link between chronological age and formal learning and opportunity focus is in line with findings from earlier research (Grima, 2011; Kanfer \& Ackerman, 2004; Lang \& Carstensen, 2002; Livingstone, 1999; Urwin, 2006; Van Vianen, Dalhoeven, \& De Pater, 2011; Warr \& Birdi, 1998; Warr, 2001; Zacher \& Frese, 2009, 2011). One reason for this is that the employer is more likely to invest resources in those employees who are more likely to remain longer in the workforce, rather than those who may retire soon. We did not find such an indirect effect via informal learning from others. This can be explained by the employees' relative independence from their employers' resources when engaging in social learning activities. Activities such as asking for information, feedback, and help do not typically require the formal allocation of company resources. Therefore, the employees have more freedom to take such 
developmental actions. These findings increase our understanding of how chronological age and employability are linked. While previous literature has raised criticism concerning the usage of chronological age as a predictor (Carstensen, 2006; Staudinger \& Bowen, 2011), mediators between chronological age and employability have received little attention so far.

\section{DIRECTIONS FOR FUTURE RESEARCH}

Further research may extend the theoretical framework and the empirical evidence presented in this dissertation in various ways. We focus on three avenues for further research that we deem especially important:

- the consideration of contextual aspects other than social relationships,

- a more thorough analysis of the relevant scope of employees' feedback-seeking networks, the content of learning from others, and the process of learning from others, and

- further review of the employability concept regarding its measurement, dimensionality, and impact on the organization.

\section{Considering the importance of non-social contextual influences}

Previous studies show that context matters for learning (Eraut, 2007). In this dissertation, we honor that statement in two respects. First, we conducted empirical studies across a wide range of contexts - in terms of both industry (e.g., consulting, education, information technology, public sector, start-ups) and countries (Austria, The Netherlands, India). This allows for more generalizable statements than if the research had been solely conducted in homogeneous environments. At the same time, differences among the participating organizations that cannot be fully explained by our data became apparent. For example, different national, sectoral, and organizational cultures may play a role. Specifically, previous research suggests that the climates towards learning (Froehlich, Segers, \& Van den Bossche, 2014; Froehlich, 2014) and towards age (Staudinger \& Bowen, 2011) both play a role for (older) employees' work-related learning. Further research could study these contextual influences in greater detail. 
Second, we have focused on employees' social context. We did so because previous research has stressed the importance of the social environment for learning (e.g., Boud \& Middleton, 2003; Eraut, 2007). Therefore, we focused on informal learning from others: information-, feedback-, and help-seeking. This focus is most prevalent in Chapter 6, where we analyze employees' feedback-seeking using social network analysis. Future research may also consider other features of the context and use a broader definition of informal learning, for example by including the learning value of the tasks. This may include features such as task variety or task complexity, which have been found to affect older people's decision-making and learning (Finucane, Mertz, Slovic, \& Schmidt, 2005; Nembhard, 2000; Queen, Hess, Ennis, Dowd, \& Grühn, 2012). Put differently, the conceptualization of informal learning may be extended to include more than merely learning from others. For example, in an ongoing and related research project, we investigate the role of task variety (Withey, Daft, \& Cooper, 1983) and the learning value of the job (Van der Heijden et al., 2009) for employees' employability in Dutch and German organizations (Kremer, Froehlich, \& Segers, manuscript in preparation).

\section{Learning from others: From whom, what, and how?}

Future research can extend our findings in three important directions. First, the scope of the network may be extended. In this dissertation, we focused on the role of one's colleagues and supervisors for learning. The rationale behind this was that this group of people is more acquainted with the topics at work and will therefore be able to provide relevant and useful information, feedback, and help. We assume that members of this group have, on average, the greatest impact. However, people external to this group may also be a valuable source for learning. For instance, friends that work at different organizations may be helpful for discovering new trends (anticipation \& optimization) or information may be exchanged in communities of practice that do not match the formal structure of the organization (Rehm, Gijselaers, \& Segers, 2014). Also, contacts through sports clubs, family members, or charities may influence one's employability. Now that we have elaborated on the role of colleagues and supervisors for learning in terms of employability, we may extend this 
focus to also include other people. In a similar vein, future research may consider aspects other than homophily that shape feedback-seeking from others. In this research, we have exclusively focused on demographic aspects, which have been found to be very influential in previous research (McPherson et al., 2001). Nevertheless, other concepts such as willingness to share (Wiese et al., 2011) or similarity in terms of values (Curry \& Kenny, 1974) may be explored. For instance, in an ongoing longitudinal research project, we investigate the role of similar personal feedback preferences (Frieling, Froehlich, \& Van den Bossche, manuscript in preparation).

Second, future research may investigate the content of information-, feedback-, and help-seeking instances. This is important, as previous research has found that, at times, feedback-seeking actually reduces performance (Kluger \& DeNisi, 1996, 1998). Future research, therefore, also needs to consider what is learned from others. This calls for a more qualitative approach to study informal learning from others to complement the findings of this dissertation.

Third, the process of learning could be studied more closely. For instance, the learning strategies (Froehlich, Segers, et al., 2014) employed by the employees could be researched to give additional insight into how to facilitate learning for employability. A recent study has researched the relationship between chronological age, approaches to learning, and a variety of outcomes, such as job performance and skills development (Froehlich, 2014). Similar to the theme of this dissertation, this study has found that the relationship between chronological age and learning outcomes is partially mediated by learning approaches. Therefore, future research may study this aspect of the learning process and how it relates to employability in greater detail.

\section{Employability: Reconsidering measurement, dimensionality, and organizational benefits}

Future research may consider three themes about employability. First, the conceptualization and measurement of employability as selfperceived employability requires reflection. In this dissertation, we have used self-rated instruments to gauge employability. This is in line with previous studies, which suggest that perceived employability is more 
important than potential employers' rating. After all, employees act based on their own perceptions (Dries, Forrier, De Vos, \& Pepermans, 2014). The importance of self-appraised employability can be inferred from Lazarus and Folkman's (1984) transactional stress theory (Kinnunen, Mäkikangas, Mauno, Siponen, \& Nätti, 2011). This theory postulates that stress arises when people perceive that they cannot cope with the environment's demands (Lazarus \& Folkman, 1987). Consequently, employees who perceive themselves as highly employable feel less threatened by the environment and experience less strain (Berntson \& Marklund, 2007). Nevertheless, research has found that employees appraise their employability differently than their supervisors do (Van der Heijden, Gorgievski, \& De Lange, 2015). The employer's perspective can hardly be ignored, since decisions made by the employer, such as lay-offs or promotions, can affect employees' perception of their own employability. Therefore, future research may consider multiple sources to estimate employee's employability. In a different vein, it needs to be recognized that self-perceived employability may not only be improved by developmental measures that improve employees' competences, but also by raising awareness about the competences that employees already possess and the opportunities they provide. Further research may investigate how interventions that allow employees to take stock of their competences and to assess their opportunities on the labor market affect their self-perceived employability.

Second, the dimensions of employability and their interrelations need to be considered. Throughout this dissertation, we included multiple dimensions of employability for each empirical study, for which we expected similar results. For instance, in Chapter 3, we hypothesized positive effects of informal learning from others on occupational expertise, anticipation and optimization, and personal flexibility. We did so because previous research offers little guidance concerning different effects of learning on different dimensions of employability. However, some of our studies found different effects for different dimensions of employability. This hints at potential differences between the dimensions that have not yet been empirically explored. Dependencies between the dimensions need to be recognized. For instance, a certain degree of job-specific occupational expertise may be 
needed to assess which upcoming trends are relevant and will have an impact (anticipation and optimization). Also, a high level of occupational expertise may make it easier to adjust to change (personal flexibility) or serve the organization's goals and exert control (corporate sense). Preliminary findings of a recent investigation using Rasch analysis (Froehlich, Liu, \& Van der Heijden, 2015) support this view. The evidence suggests that occupational expertise is needed even for a low level of employability, while the more generic competences, such as anticipation and optimization and corporate sense, become more important for employees with higher levels of employability.

Organizations that offer developmental environments for employability are potentially more attractive for employees. However, more direct positive effects of employability on the bottom have also been suggested by Van der Heijde and Van der Heijden (2006). For example, a workforce that has sufficient occupational expertise and a good grasp of current trends and developments may be important for producing innovations. For instance, two recent studies suggest that employability positively enhances innovative work behavior (Froehlich, Messmann, Le Van, Beausaert, \& Segers, 2015; Stoffers, Van der Heijden, \& Notelaers, 2014), which encompasses all activities to develop innovations (Messmann \& Mulder, 2012). In sum, future research may consider the organizational outcomes of an employable workforce more explicitly. 


\section{REFERENCES}

Ames, C. (1992). Classrooms: Goals, Structures, and Student Motivation. Journal of Eduactional Psychology, 84(3), 261-271.

Anderson, L. B. (2013). How frames present BMW as embracing an aging workforce. Public Relations Review, 39(5), 484-490. doi:10.1016/j.pubrev.2013.02.003

Apfelbaum, E. P., Phillips, K. W., \& Richeson, J. A. (2014). Rethinking the Baseline in Diversity Research: Should We Be Explaining the Effects of Homogeneity? Perspectives on Psychological Science, 9, 235-244. doi:10.1177/1745691614527466

Bal, P. M., Kooij, D. T. A. M., \& Rousseau, D. M. (2015a). Introduction to aging workers and the employee-employer relationship. In P. M. Bal, D. T. A. M. Kooij, \& D. M. Rousseau (Eds.), Aging workers and the employeeemployer relationship (pp. 1-9). Dordrecht: Springer.

Bal, P. M., Kooij, D. T. A. M., \& Rousseau, D. M. (2015b). Conclusion and Future Research. In P. M. Bal, D. T. A. M. Kooij, \& D. M. Rousseau (Eds.), Aging Workers and the Employee-Employer Relationship (pp. 261-268). Cham: Springer Netherlands. doi:10.1007/978-3-319-08007-9_15

Bamberger, P. A. (2009). Employee Help-Seeking: Antecedents, Consequences and new Insights for Future Research. In J. J. Martocchio \& H. Liao (Eds.), Research in Personnel and Human Resource Management (Vol. 28, pp. 49-98). Bingley: Emerald Group Publishing. doi:10.1108/S0742-7301(2009)0000028005

Beausaert, S. A. J., Segers, M. S. R., Van der Rijt, J., \& Gijselaers, W. H. (2011). The Use of Personal Development Plans (PDPs) in the Workplace: A Literature Review. In P. Van den Bossche, W. H. Gijselaers, \& R. G. Milter (Eds.), Building Learning Experiences in a Changing World (Vol. 3, pp. 235265). Dordrecht: Springer Netherlands. doi:10.1007/978-94-007-0802-0

Berntson, E., \& Marklund, S. (2007). The Relationship Between Employability and Subsequent Health. Work \& Stress, 21(3), 279-292. doi:10.1080/02678370701659215 
Billett, S. (2011). Promoting Lifelong Employability for Workforce Aged Over 45: Singaporean Workers' Perspectives. International Journal of Continuing Education and Lifelong Learning, 3(2), 57-73.

Boud, D., \& Middleton, H. (2003). Learning from others at work: communities of practice and informal learning. Journal of Workplace Learning, 15(5), 194-202. doi:10.1108/13665620310483895

Brett, J. F., \& VandeWalle, D. (1999). Goal orientation and goal content as predictors of performance in a training program. Journal of Applied Psychology, 84(6), 863-873. doi:10.1037//0021-9010.84.6.863

Carstensen, L. L. (2006). The Influence of a Sense of Time on Human Development. Science, 312(5782), 1913-1915. doi:10.1126/science. 1127488

CEDEFOP. (2008). Terminology of European education and training policy. Luxembourg: Office for Official Publications of the European Communities.

Curry, T. J., \& Kenny, D. A. (1974). The Effects of Perceived and Actual Similarity in Values and Personality in the Process of Interpersonal Attratction. Quality and Quantity, 8, 27-44.

De Lange, A. H., Bal, P. M., Van der Heijden, B. I. J. M., De Jong, N., \& Schaufeli, W. B. (2011). When I'm 64: Psychological Contract Breach, Work Motivation and the Moderating Roles of Future Time Perspective and Regulatory Focus. Work \& Stress, 25(4), 338-354. doi:10.1080/02678373.2011.632610

De Vos, A., De Hauw, S., \& Van der Heijden, B. I. J. M. (2011). Competency development and career success: The mediating role of employability. Journal of Vocational Behavior, 79(2), 438-447. doi:10.1016/j.jvb.2011.05.010

Department for Business Innovation and Skills. (2011). Phasing Out the Default Retirement Age: Government Response to Consultation - Impact Assessment. London: Department for Business Innovation and Skills.

Dries, N., Forrier, A., De Vos, A., \& Pepermans, R. (2014). Self-perceived employability, organization-rated potential, and the psychological 
contract. Journal of Managerial Psychology, 29(5), 565-581. doi:10.1108/JMP-04-2013-0109

Ebner, N. C., Freund, A. M., \& Baltes, P. B. (2006). Developmental changes in personal goal orientation from young to late adulthood: from striving for gains to maintenance and prevention of losses. Psychology and Aging, 21(4), 664-78. doi:10.1037/0882-7974.21.4.664

Elliot, A. J., \& McGregor, H. A. (2001). A 2x2 Achievement Goal Framework. Journal of Personality and Social Psychology, 80(3), 501-519.

Eraut, M. (2007). Learning from Other People in the Workplace. Oxford Review of Education, 33(4), 403-422. doi:10.1080/03054980701425706

Finucane, M. L., Mertz, C. K., Slovic, P., \& Schmidt, E. S. (2005). Task complexity and older adults' decision-making competence. Psychology and Aging, 20(1), 71-84. doi:10.1037/0882-7974.20.1.71

Froehlich, D. E. (2014). Die Transition zur alternden Belegschaft: Auswirkungen auf das Lernen am Arbeitsplatz [The transition to the aging workforce: implications for workplace learning]. Paper presented at the Annual Meeting for the Section Adult Education of the DGfE. Frankfurt. doi:http://dx.doi.org/10.6084/m9.figshare.1192847

Froehlich, D. E., Beausaert, S. A. J., Segers, M. S. R., \& Gerken, M. (2014). Learning to Stay Employable. Career Development International, 19(5), 508-525. doi:10.1108/CDI-11-2013-0139

Froehlich, D. E., Liu, M., \& Van der Heijden, B. I. J. M. (2015). Competencebased employability: A Rasch analysis. Paper presented at the 16th biennial EARLI conference for research on learning and instruction. Limassol.

Froehlich, D. E., Messmann, G., Le Van, J., Beausaert, S. A. J., \& Segers, M. S. R. (2015). The effects of diversity and feedback exchange in the social network on innovative work behavior. Paper presented at the 16th biennial EARLI conference for research on learning and instruction. Limassol.

Froehlich, D. E., Segers, M. S. R., \& Van den Bossche, P. (2014). Informal Workplace Learning in Austrian Banks: The Influence of Learning Approach, Leadership Style, and Organizational Learning Culture on 
Managers' Learning Outcomes. Human Resource Development Quarterly, 25(1), 29-57. doi:10.1002/hrdq.21173

Gegenfurtner, A., \& Vauras, M. (2012). Age-related differences in the relation between motivation to learn and transfer of training in adult continuing education. Contemporary Educational Psychology, 37(1), 3346. doi:10.1016/j.cedpsych.2011.09.003

Gellert, P., Ziegelmann, J. P., Lippke, S., \& Schwarzer, R. (2012). Future time perspective and health behaviors: temporal framing of self-regulatory processes in physical exercise and dietary behaviors. Annals of Behavioral Medicine, 43(2), 208-18. doi:10.1007/s12160-011-9312-y

Granovetter, M. S. (1973). The Strength of Weak Ties. American Journal of Sociology, 78(6), 1360-1380. doi:10.1086/225469

Grima, F. (2011). The influence of age management policies on older employee work relationships with their company. International Journal of Human Resource Management, 22(6), 1312-1332. doi:10.1080/09585192.2011.559101

Groot, W., \& Van den Brink, H. M. (2000). Education, training and employability. Applied Economics, 32(5), 573-581. doi:10.1080/000368400322471

Hall, B. H., Mairesse, J., \& Turner, L. (2007). Identifying age, cohort, and period effects in scientific research productivity: discussion and illustration using simulated and actual data on french physicists. Economics of Innovation and New Technology, 16(2), 37-41.

Janis, I. L. (1982). Groupthink. Psychological studies of policy decisions and fiascos (2nd ed.). Boston, MA: Houghton Mifflin Company.

Janssen, O., \& Prins, J. (2007). Goal orientations and the seeking of different types of feedback information. Journal of Occupational and $\begin{array}{lll}\text { Organizational } \quad \text { Psychology, 235-249. } & \text { 80(2), }\end{array}$ doi:10.1348/096317906X103410

Kanfer, R., \& Ackerman, P. L. (2004). Aging, Adult Development, and Work Motivation. Academy of Management Review, 29(3), 440-458. doi:10.2307/20159053 
Kinnunen, U., Mäkikangas, A., Mauno, S., Siponen, K., \& Nätti, J. (2011). Perceived employability: Investigating outcomes among involuntary and voluntary temporary employees compared to permanent employees. Career Development International, 16(2), 140-160. doi:10.1108/13620431111115604

Kluger, A. N., \& DeNisi, A. (1996). The Effects of feedback intervention on performance: A historical review, a meta-analysis, and a preliminary feedback intervention theory. Psychological Bulletin, 119(2), 254-284. doi:10.1037/0033-2909.119.2.254

Kluger, A. N., \& DeNisi, A. (1998). Feedback Interventions: Toward the Understanding of a Double-Edged Sword. Current Directions of Psychology.

Kooij, D. T. A. M., Bal, P. M., \& Kanfer, R. (2014). Future time perspective and promotion focus as determinants of intraindividual change in work motivation. Psychology and Aging, 29(2), 319-328.

Kooij, D. T. A. M., De Lange, A. H., Jansen, P. G. W., Kanfer, R., \& Dikkers, J. S. E. (2011). Age and Work-related Motives: Results of a Meta-analysis. Journal of Organizational Behavior, 32(1), 197-225. doi:10.1002/job

Lang, F. R., \& Carstensen, L. L. (2002). Time counts: Future time perspective, goals, and social relationships. Psychology and Aging, 17(1), 125-139. doi:10.1037//0882-7974.17.1.125

Lazarus, R. S., \& Folkman, S. (1984). Stress, Appraisal, and Coping. New York: Springer.

Lazarus, R. S., \& Folkman, S. (1987). Transactional theory and research on emotions and coping. European Journal of Personality, 1, 141-169. doi:10.1002/per.2410010304

Livingstone, D. W. (1999). Exploring the icebergs of adult learning: Findings of the first Canadian survey of informal learning practices. Canadian Journal for the Study of Adult Education, 13(2), 49-72.

Livingstone, D. W. (2001). Adults' Informal Learning: Definitions, Findings, Gaps and Future Research (No. 21). Toronto, Ontario: Centre for the Study of Education and Work. 
Loch, C. H., Sting, F. J., Bauer, N., \& Mauermann, H. (2010). How BMW Is Defusing the Demographic Time Bomb. Harvard Business Review, (3), 99-102.

Marsick, V. J., \& Watkins, K. E. (2001). Informal and Incidental Learning. New Directions for Adult and Continuing Education, 2001(89), 25-34. doi:10.1002/ace.5

McPherson, M., Smith-Lovin, L., \& Cook, J. M. (2001). Birds of a Feather: Homophily in Social Networks. Annual Review of Sociology, 27, 415-444.

Messmann, G., \& Mulder, R. H. (2012). Development of a measurement instrument for innovative work behaviour as a dynamic and contextbound construct. Human Resource Development International, 15(1), 4359. doi:10.1080/13678868.2011.646894

Nembhard, D. (2000). The effects of task complexity and experience on learning and forgetting: A field study. Human Factors, 42(2), 272-286.

Noordzij, G., Van Hooft, E. A. J., Van Mierlo, H., Van Dam, A., \& Born, M. P. (2013). The Effects of a Learning-Goal Orientation Training on SelfRegulation: A Field Experiment Among Unemployed Job Seekers. Personnel Psychology, 66(3), 723-755. doi:10.1111/peps.12011

Ogilvie, D. M., Rose, K. M., \& Heppen, J. B. (2010). A Comparison of Personal Project Motives in Three Age Groups. Basic and Applied Social Psychology, 23(3), 207-215.

Park, W.-W. (1990). A Review of research on Groupthink. Journal of Behavioral Decision Making, 3(4), 229-245.

Phalet, K., Andriessen, I., \& Lens, W. (2004). How Future Goals Enhance Motivation and Learning in Multicultural Classrooms. Educational Psychology Review, 16(1), 59-89. doi:10.1023/B:EDPR.0000012345.71645.d4

Queen, T. L., Hess, T. M., Ennis, G. E., Dowd, K., \& Grühn, D. (2012). Information Search and Decision Making: Effects of Age and Complexity on Strategy Use. Psychology and Aging, 27(4), 817-824. doi:10.1037/a0028744 
Rehm, M., Gijselaers, W., \& Segers, M. S. R. (2014). Effects of Hierarchical Levels on Social Network Structures within Communities of Learning, 38-55.

Simons, J., Vansteenkiste, M., Lens, W., \& Lacante, M. (2004). Placing Motivation and Future Time Perspective Theory in a Temporal Perspective. Educational Psychology Review, 16(2), 121-139. doi:10.1023/B:EDPR.0000026609.94841.2f

Staudinger, U. M., \& Bowen, C. E. (2011). A systemic approach to aging in the work context. Zeitschrift für ArbeitsmarktForschung, 44(4), 295-306. doi:10.1007/s12651-011-0086-2

Stoffers, J. M. M., Van der Heijden, B. I. J. M., \& Notelaers, G. (2014). Towards a moderated mediation model of innovative work behaviour enhancement. Journal of Organizational Change Management, 27, 642659. doi:10.1108/JOCM-05-2014-0105

Urwin, P. (2006). Age discrimination: legislation and human capital accumulation. Employee Relations, 28(1), 87-97. doi:10.1108/01425450610633082

Van der Heijde, C. M., \& Van der Heijden, B. I. J. M. (2006). A competencebased and multidimensional operationalization and measurement of employability. Human Resource Management, 45(3), 449-476. doi:10.1002/hrm.20119

Van der Heijden, B. I. J. M., Boon, J., Van der Klink, M. R., \& Meijs, E. (2009). Employability Enhancement through Formal and Informal Learning: An Empirical Study among Dutch Non-Academic University Staff Members. International Journal of Training and Development, 13(1), 19-37. doi:10.1111/j.1468-2419.2008.00313.x

Van der Heijden, B. I. J. M., Gorgievski, M. J., \& De Lange, A. H. (2015). Learning at the workplace and sustainable employability: a multisource model moderated by age. European Journal of Work and Organizational Psychology, 1-18. doi:10.1080/1359432X.2015.1007130

Van der Klink, M. R., Van der Heijden, B. I. J. M., Boon, J., \& Williams van Rooij, S. (2014). Exploring the contribution of formal and informal learning to 
academic staff member employability. Career Development International, 19(3), 337-356. doi:10.1108/CDI-03-2013-0030

Van Dierendonck, D., \& Van der Gaast, E. (2013). Goal orientation, academic competences and early career success. Career Development International, 18(7), 694-711. doi:10.1108/CDI-01-2013-0003

Van Vianen, A. E. M., Dalhoeven, B. A. G. W., \& De Pater, I. E. (2011). Aging and training and development willingness: Employee and supervisor mindsets. Journal of Organizational Behavior, 32(2), 226-247. doi:10.1002/job.685

Van Yperen, N. W., \& Orehek, E. (2013). Achievement goals in the workplace: Conceptualization, prevalence, profiles, and outcomes. Journal of Economic Psychology, 38, 71-79. doi:10.1016/j.joep.2012.08.013

Warr, P. B. (2001). Age and work behaviour: physical attributes, cognitive abilities, knowledge, personality traits and motives. In C. L. Cooper \& I. T. Robertson (Eds.), International Review of Industrial and Organizational Psychology (pp. 1-36). London: Wiley Publishing.

Warr, P. B., \& Birdi, K. S. (1998). Employee age and voluntary development activity. International Journal of Training and Development, 2(3), 190-204. doi:10.1111/1468-2419.00047

Wiese, J., Kelley, P. G., Cranor, L. F., Dabbish, L., Hong, J. I., \& Zimmerman, J. (2011). Are you close with me? are you nearby? Investigating social groups, closeness, and willingness to share. Proceedings of the 13th international conference on Ubiquitous computing - UbiComp '11, 197. doi:10.1145/2030112.2030140

Withey, M., Daft, R. L., \& Cooper, W. H. (1983). Measures of Perrow's Work Unit Technology: An Empirical Assessment and a New Scale. Academy of Management Journal, 26(1), 45-63.

Zacher, H., \& Frese, M. (2009). Remaining time and opportunities at work: Relationships between age, work characteristics, and occupational future time perspective. Psychology and Aging, 24(2), 487-493. doi:10.1037/a0015425

Zacher, H., \& Frese, M. (2011). Maintaining a focus on opportunities at work: The interplay between age, job complexity, and the use of selection, 
optimization, and compensation strategies. Journal of Organizational Behavior, 32(1), 291-318. doi:10.1002/job.683 
192 | General Discussion 


\section{Valorization Addendum}

\section{INTRODUCTION}

In this valorization addendum, we discuss the possibilities of how the knowledge created in this dissertation is transferred into practice. We begin with analyzing three relevant groups of stakeholders. Subsequently, we list the products and activities that aid the implementation in practice that emerged during the research process and beyond.

\section{SOCIAL AND ECONOMIC RELEVANCE FOR THREE TARGET GROUPS}

Next to the academic community, the findings of this dissertation are especially relevant to three groups of stakeholders: national and supranational policymakers and policy advisors, companies and consultants, and individuals.

\section{National and supranational policymakers and policy advisors}

The demographic shift puts enormous stress on the welfare state: an older population means more health expenditures, more pension payments, and less taxes. Therefore, many governments increased the default retirement age. However, statistics show that many people drop out of the workforce well before the retirement date (OECD, 2014). This may indicate a lack of employees' ability to create and fulfill work for themselves (employability; cf. Van der Heijde \& Van der Heijden, 2006). Therefore, raising the level of the labor force's employability is a primary goal of national and supranational policymakers. For instance, the European Commission's EUROPE 2020 program prioritizes inclusive growth (European Commission, 2010). This means, amongst others, that the employment rates of women, younger, and older workers should be increased.

Another example is the certification process initiated by the Austrian government, in which Austrian companies can get certified as having good and fair age management practices in place (Federal Ministry of Labour Social Affairs and Consumer Protection, 2015). To a large extent, this certification focuses on issues in the domain of health management. Especially for information-based work, which is increasing in the Western 
societies, the physical requirements to work are relatively low. The findings of this dissertation suggest to also pay attention to the competences needed to create and fulfill work for oneself on top of the physical requirements of working.

\section{Companies, other organizational entities, and consultants}

The demographic shift hits organizations, too (Loch, Sting, Bauer, \& Mauermann, 2010). The findings of this dissertation and the products generated in the process of doing the research are aimed at helping organizations to meet this challenge. This is reflected by the fact that the project was funded by $\mathrm{A}+\mathrm{O}$ Metalelektro, an association of companies that includes more than 159,000 people in the metal-electro sector ( $A+O$ Metalelektro, 2015).

First, organizations may use the "From Learning 2 Innovation" application (Froehlich, 2014a) to get an overview of their workforce's informal learning from others and a benchmark against other companies. What is more, suggestions of what specific changes may be implemented can be offered upon this analysis. For example, the results may show that the level of interaction between the employees is relatively low. To stimulate informal learning from others, it might be feasible to re-structure the task packages, so that people have to collaborate with each other, rather than working in parallel. Also, interested companies find information about the topic and contact information of the researchers involved in the project on the homepage of the project. To further reduce the gap between academia and practice, we have published also in practitioners' journals (Beausaert, Van Erp, Froehlich, Segers, \& Gerken, 2014) and gave presentations in nonacademic settings (e.g., Froehlich, 2012a, 2012b, 2014b). In the next year, we will intensify this effort.

Second, the findings of this dissertation provide pathways that help organizations in supporting their employees' development of employability.

- While data about chronological age is often cheaply and readily accessible, other factors may be more useful for decision-making (Zacher, Heusner, Schmitz, Zwierzanska, \& Frese, 2010). Human resource management practices are often targeted at a certain age group of workers (Kooij, Jansen, Dikkers, \& De Lange, 2014). 
However, our results indicate that it might not be the age per se that matter when it comes to, for example, the undertaking of developmental measures, but future time perspective.

- Organizations may educate against ageism, for example by fostering high-quality intergenerational contact (Iweins, Desmette, Yzerbyt, \& Stinglhamber, 2013) or offering age awareness trainings (Armstrong-Stassen \& Templer, 2005), and reconsider their human resource management approach towards older employees (Kooij et al., 2013, 2014).

- Employees' learning should be supported and stimulated irrespective of the employees' age. For employees it is especially important to be aware about the strong effects of informal learning from others in their professional network on their employability and to become proactive in exploiting these learning opportunities.

Third, companies may also use the knowledge gained from this dissertation to attract new employees and to retain old ones. Since companies do not provide the same level of job security as they did a few decades ago, having the competences to be employable matters (Dries, Forrier, De Vos, \& Pepermans, 2014). Offering a job that will enhance people's employability is therefore an attractive selling point on the labor market.

Fourth, for consultants, the social network analyses presented in Chapter 6 is an interesting approach, as it allows to perform state of the art research in a relatively small setting (e.g., a single unit of a company). From this, evidence-based interventions can be implemented.

\section{Individuals and career advisors}

Aging is, first of all, an individual phenomenon. Staying employable and increasing one's potential of employment and having an income also in higher age is important. After all, living longer also means that expenses need to be covered for a longer time. However, older employees are often the first victims to restructuration measures and people that lose their job in their fifties often have trouble finding new employment. The findings and 
implications of this dissertation can help individuals to reflect and act upon their employability.

Moreover, the perspective of the protean career suggests that the responsibility for one's career has shifted from the organization to the individual (Briscoe, Hall, \& DeMuth, 2006; Hall, 1996, 2004). In this respect, one's employability becomes even more important. Individual employees may therefore use the research findings to optimize their attitude towards their future career and their actual learning behavior. Specifically, the "From Learning 2 Innovation" application, which is based on the dissertation's findings, may be freely used by any interested person (Froehlich, 2014a).

\section{ACTIVITIES AND PRODUCTS}

The project, in which this dissertation is embedded in, has produced a number of specific products and services: academic literature and presentations, practitioners literature, workshops for practitioners, a smartphone and web application.

\section{Academic literature and presentations}

Next to offering solutions for practice, dissemination of the results also in the academic community is important. Accordingly, we made it a priority to present the findings of our studies at international conferences in the past (e.g., at the European Association for Research on Learning and Instruction (EARLI) conference, at the American Educational Research Association (AERA) general meeting, at the International Network for Social Network Analysis' Sunbelt conference, or at the German Educational Research Association (GERA) general meeting) and publish in indexed and peer-reviewed academic journals (e.g., Career Development International, Vocations and Learning, and The International Journal of Human Resource Management). Furthermore, while not part of this dissertation, two book chapters were written during the project. Moreover, we participated in an interdisciplinary research group ("Maintaining a focus upon learning at work for older employees: An interdisciplinary perspective") within the EARLICentre for Innovative Research framework, which allows cross-disciplinary exchange of ideas and information. 
Next to developing and testing the main model presented in this dissertation, we are currently also involved in thinking about the concept of employability as such. For instance, we are involved in developing a shortened version of Van der Heijde and Van der Heijden's (2006) employability scale. This is important, because while the original scale has good psychometric features, it is fairly long. To allow for more large-scale research in this field, we believe that a validated short-form measurement is a worthwhile endeavor. This creates value by allowing researchers to investigate more complex models that include more variables simultaneously or to simply attract higher sample sizes. Moreover, practitioners may find the instrument more appealing to use as an internal human resource management tool.

Furthermore, we are analyzing Van der Heijde and Van der Heijden's (2006) employability scale using Rasch analysis (Froehlich, Liu, \& Van der Heijden, 2015). This is not only done to confirm the soundness of the instrument from the perspective of Rasch measurement, but we also believe that this approach lets us understand the concept more fully. First analyses suggest that not all five competences of employability are equal. Occupational expertise seems to be the foundation of employability: It is "needed to play" rather than "needed to win". After an adequate level of occupational expertise has been reached, however, the utility of additional expertise is marginal. Instead, the other competences become more important. This confirms the original idea of Van der Heijden (personal communication), which, however, so far has remained without empirical evidence. This way of thinking adds considerable value to individuals, organizations, and policymakers, as it defines a clear pathway of how to improve from one level of employability to the next. Since the individuals' current status is taken into account, more specific recommendations can be given.

\section{Practitioners literature}

While the academic audience is an important target group, we also stressed the communication with practitioners. Therefore, we held many presentations at company sites and at practitioners conferences and published in practitioners' journals (e.g., Beausaert et al., 2014). The 
publication of book chapters makes the content more accessible to practitioners as well (e.g., Raemdonck, Beausaert, Froehlich, Kochoian, \& Meurant, 2015). Furthermore, we created a website to communicate also online (Froehlich, 2014a) and a brochure (Beausaert et al., 2015).

The dissertation, as 'work-in-progress', was awarded with the Theodor Körner Prize (Froehlich, 2014c). Since this is one of the most prestigious awards in Austria (Wikipedia, 2015), this makes the research more accessible to the public.

\section{Workshops for practitioners}

Presentations to practitioners often had the character of a workshop. For example, during an unfreezing workshop with workers in the metal-electro sector, participants were stimulated and supported to reflect upon their learning behaviors and their employability $(A+O$ Metalelektro, 2013). While this was often part of data collection, it at the same time was an opportunity to raise awareness about the topics of employability and informal learning from others.

\section{Smartphone and web application and webpage}

The "From Learning 2 Innovation" app is available for iOS and android smartphones as well as on the web. It may be freely accessed by anybody and allows self-assessment of one's informal learning from others (Froehlich, 2014a).

\section{INNOVATION}

The project is innovative in three major respects. First, the projects advances the academic understanding in this field. This point was made specific throughout the dissertation. Second, we opted for a mix of methods that is innovative in this field of research. For instance, we are not aware of any other study that has used social network analysis to analyze informal learning from others and its effects on employability. Third, we regard the valorization and dissemination strategy as innovative, as it targets multiple stakeholders via various channels, such as an web page and a smartphone application. While employability is a concern for everybody, such a holistic way of communication of research results is not common in this field. 


\section{REFERENCES}

A+O Metalelektro. (2013). Van leren naar innoveren. Retrieved February 10, 2015, from http://www.ao-metalektro.nl/doorstroom/doorstroomartikelen/20-van-leren-naar-innoveren

A+O Metalelektro. (2015). Homepage. Retrieved February 5, 2015, from http://www.ao-metalektro.nl/

Armstrong-Stassen, M., \& Templer, A. (2005). Adapting Training for Older Employees: The Canadian Response to an Aging Workforce. Journal of Management Development, 24(1), 57-67. doi:10.1108/02621710510572353

Beausaert, S. A. J., Bollen, K., Van Erp, J., Froehlich, D. E., Gerken, M., Kochoian, N., ... Segers, M. S. R. (2015). Old and out? Toch niet! Over leren, leeftijd en duurzame inzetbaarheid. Maastricht.

Beausaert, S. A. J., Van Erp, J., Froehlich, D. E., Segers, M. S. R., \& Gerken, M. (2014). De invloed van leeftijd en attitudes op leren en inzetbaarheid: Een kunstenaar gaat nooit met pensioen [The influence of age and attitudes on learning and employability: An artist never retires]. Opleiding \& Ontwikkeling, (2), 23-26.

Briscoe, J. P., Hall, D. T., \& DeMuth, R. L. F. (2006). Protean and Boundaryless Careers: An Empirical Exploration. Journal of Vocational Behavior, 69(1), 30-47. doi:10.1016/j.jvb.2005.09.003

Dries, N., Forrier, A., De Vos, A., \& Pepermans, R. (2014). Self-perceived employability, organization-rated potential, and the psychological contract. Journal of Managerial Psychology, 29(5), 565-581. doi:10.1108/JMP-04-2013-0109

European Commission. (2010). Employment in Europe 2010. Luxembourg: Publications Office of the European Union. doi:10.2767/72770

Federal Ministry of Labour Social Affairs and Consumer Protection. (2015). NESTOR GOLD. Retrieved from http://www.nestorgold.at/

Froehlich, D. E. (2012a). 50 shades of the greying workforce. Presentation at the Science Slam Austria. Vienna.

Froehlich, D. E. (2012b). Breaking the Walls of the Greying Workforce. Presentation at the Falling Walls Labs. Vienna. 
Froehlich, D. E. (2014a). From Learning 2 Innovation. Retrieved from http://www.fl2i.com/

Froehlich, D. E. (2014b). Breaking the Walls of Age. Presentation at the Falling Walls Labs. Vienna.

Froehlich, D. E. (2014c). Theodor Körner Prize. Vienna: Theodor Körner Fonds.

Froehlich, D. E., Liu, M., \& Van der Heijden, B. I. J. M. (2015). Competencebased employability: A Rasch analysis. Paper presented at the 16th biennial EARLI conference for research on learning and instruction. Limassol.

Hall, D. T. (1996). Protean Careers of the 21st Century. Academy of Management Executive, 10(4), 8-16.

Hall, D. T. (2004). The protean career: A quarter-century journey. Journal of Vocational Behavior, 65(1), 1-13. doi:10.1016/j.jvb.2003.10.006

Iweins, C., Desmette, D., Yzerbyt, V., \& Stinglhamber, F. (2013). Ageism at work: The impact of intergenerational contact and organizational multiage perspective. European Journal of Work and Organizational Psychology, 22(3), 331-346. doi:10.1080/1359432X.2012.748656

Kooij, D. T. A. M., Guest, D. E., Clinton, M., Knight, T., Jansen, P. G. W., \& Dikkers, J. S. E. (2013). How the impact of HR practices on employee well-being and performance changes with age. Human Resource Management Journal, 23(1), 18-35. doi:10.1111/1748-8583.12000

Kooij, D. T. A. M., Jansen, P. G. W., Dikkers, J. S. E., \& De Lange, A. H. (2014). Managing aging workers: a mixed methods study on bundles of HR practices for aging workers. International Journal of Human Resource Management, 1-21. doi:10.1080/09585192.2013.872169

Loch, C. H., Sting, F. J., Bauer, N., \& Mauermann, H. (2010). How BMW Is Defusing the Demographic Time Bomb. Harvard Business Review, (3), 99-102.

OECD. (2014). OECD.Stat Database. doi:10.1787/20752342

Raemdonck, I., Beausaert, S. A. J., Froehlich, D. E., Kochoian, N., \& Meurant, C. (2015). Age related changes in learning and employability. In D. 
Rosseau, D. T. A. M. Kooij, \& P. M. Bal (Eds.), Aging Workers and the Employee-Employer Relationship (pp. 163-184).

Van der Heijde, C. M., \& Van der Heijden, B. I. J. M. (2006). A competencebased and multidimensional operationalization and measurement of employability. Human Resource Management, 45(3), 449-476. doi:10.1002/hrm.20119

Wikipedia. (2015). Theodor Körner Prize. Retrieved from http://en.wikipedia.org/wiki/Theodor_Körner_Prize

Zacher, H., Heusner, S., Schmitz, M., Zwierzanska, M. M., \& Frese, M. (2010). Focus on opportunities as a mediator of the relationships between age, job complexity, and work performance. Journal of Vocational Behavior, 76(3), 374-386. doi:10.1016/j.jvb.2009.09.001 
202 | VALORIZATION ADDENDUM 


\section{About the Author}

\section{BIOGRAPHY}

Dominik Emanuel Froehlich (1986) obtained a Bachelor of Science (summa cum laude) in Business Administration at the Vienna University of Economics and Business, Austria and a Master of Science (cum laude) in International Business at Maastricht University, The Netherlands. Further relevant education includes a Bachelor in Computer Science ${ }^{*}$ at the University of the People, United States and participation in the soQua program, which is a training program providing further professional qualification in the social sciences sponsored by the Federal Ministry of Science, Research and Economics in Austria.

After a career in the consulting sector he started his academic career as a doctoral researcher in the Department for Educational Research and Development at Maastricht University in 2014. Soon, the planned dissertation project was awarded with the prestigious Theodor Körner Prize. He presented his research work at, for instance, conferences of the European Association for Research on Learning and Instruction (EARLI) and the American Educational Research Association (AERA). He published in academic journals such as the International Journal of Human Resource Management, Human Resource Development Quarterly, Career Development International, and Vocations and Learning.

Dominik collaborates in the EARLI Center for Innovative Research (ECIR) "Maintaining a focus upon learning at work for older employees". His work draws predominantly from quantitative methods such as Structural Equation Modeling and Social Network Analysis. Next to giving methods workshops in both intra and inter-university settings, Dominik supervises graduate students in their thesis writing process.

\footnotetext{
* Expected completion 2015.
} 


\section{LIST OF PUBLICATIONS}

\section{Published and in press}

Froehlich, D. E., Beausaert, S. A. J., \& Segers, M. S. R. (In press). Great Expectations: The relationship between Future Time Perspective, Learning from Others, and Employability. Vocations and Learning. doi:10.1007/s12186-015-9131-6

Raemdonck, I., Froehlich, D.E., Beausaert, S.A.J. and Meurant, C. (2015), “Age related changes in learning and employability", in Rosseau, D., Kooij, D.T.A.M. and Bal, P.M. (Eds.), Aging Workers and the Employee-Employer Relationship, pp. 163-184.

Froehlich, D. E., Beausaert, S. A. J., \& Segers, M. S. R. (2014). Age, employability and the role of learning activities and their motivational antecedents: a conceptual model. International Journal of Human Resource Management, 1-15. doi:10.1080/09585192.2014.971846

Froehlich, D. E., Beausaert, S. A. J., Segers, M. S. R., \& Gerken, M. (2014). Learning to Stay Employable. Career Development International, 19(5), 508-525. doi:10.1108/CDI-11-2013-0139

Froehlich, D. E., Segers, M. S. R., \& Van den Bossche, P. (2014). Informal Workplace Learning in Austrian Banks: The Influence of Learning Approach, Leadership Style, and Organizational Learning Culture on Managers' Learning Outcomes. Human Resource Development Quarterly, 25(1), 29-57. doi:10.1002/hrdq.21173

\section{In review}

Froehlich, D. E., Beausaert, S. A. J., \& Segers, M. S. R. (In review). Informal Learning in a Social Context: Development and Validation of a Scale measuring Information, Feedback, and Help Seeking in the Workplace.

Froehlich, D. E., Beausaert, S. A. J., \& Segers, M. S. R. (In review). Feedback Seeking in the Personal Network: The Effects on Employability and the Dangers of Homophily.

Froehlich, D. E., Beausaert, S. A. J., \& Segers, M. S. R. (In review). It's not the age, it's the attitude: Exploring the black box between age and employability. 
Gerken, M., Messmann, G., Froehlich, D.E., Beausaert, S. A. J., Mulder, R. H., \& Segers, M. (In review): Social informal learning and reflection at work as facilitators of employees' innovative work behaviour. In G. Messmann, M. Segers, \& F. Dochy (Eds.), Informal learning at work.

\section{Conference presentations}

Froehlich, D. E., Beausaert, S. A. J., \& Segers, M. S. R. (2015). Learning to Stay Employable: The Role of Employees' Feedback Seeking Network and the Dangers of Homophily. Paper presented at the XXXV Sunbelt Conference of the International Network for Social Network Analysis (INSNA). Brighton.

Froehlich, D. E., Beausaert, S. A. J., \& Segers, M. S. R. (2015). Employees' conceptions of proactive informal learning from others. Paper presented at the 16th biennial EARLI conference for research on learning and instruction. Limassol.

Froehlich, D. E., Beausaert, S. A. J., \& Segers, M. S. R. (2015). Feedback seeking and relational demography: A conceptual model of enhancing employees' employability. Paper presented at the 16th biennial EARLI conference for research on learning and instruction. Limassol.

Froehlich, D. E., Messmann, G., Le Van, J., Beausaert, S. A. J., \& Segers, M. S. R. (2015). The effects of diversity and feedback exchange in the social network on innovative work behavior. Paper presented at the 16th biennial EARLI conference for research on learning and instruction. Limassol.

Froehlich, D. E., Liu, M., \& Van der Heijden, B. I. J. M. (2015). Competencebased employability: A Rasch analysis. Paper presented at the 16th biennial EARLI conference for research on learning and instruction. Limassol.

Froehlich, D. E., Beausaert, S. A. J., \& Segers, M. S. R. (2014). Work-Related Informal Learning in a Social Context: Development and Validation of a Scale measuring Information, Feedback, and Help Seeking in the Workplace. Poster presented at the AERA Annual Meeting. Philadelphia. 
Froehlich, D. E., Beausaert, S. A. J., \& Segers, M. S. R. (2014). Feedback Seeking in the Personal Network: The Effects on Employability and the Dangers of Homophily. Paper presented at the EARLI SIG 14. Oslo.

Froehlich, D. E., Beausaert, S. A. J., \& Segers, M. S. R. (2014). Age, Attitudes, Activities: How future time perspective, goal orientation, and learning activities shape older employees' employability. Paper presented at the EARLI SIG 14. Oslo.

Beausaert, S. A. J., Gerken, M., Froehlich, D. E., \& Segers, M. S. R. (2014). Over de relatie tussen leeftijd, leren en inzetbaarheid van docenten in het hoger onderwijs. Paper presented at the ORD 2014. Groningen.

Froehlich, D. E. (2014). Die Transition zur alternden Belegschaft: Auswirkungen auf das Lernen am Arbeitsplatz. Paper presented at the Annual Meeting for the Section Adult Education of the DGfE. Frankfurt.

Froehlich, D. E., Beausaert, S. A. J., \& Segers, M. S. R. (2013). Learning to Stay Employable: The Relationship between Age, Formal and Informal Learning, and Employability. Paper presented at the 15th biennial EARLI conference for research on learning and instruction. Munich.

Froehlich, D. E., Beausaert, S. A. J., \& Segers, M. S. R. (2013). It's All about the Attitudes, not the Age: The Role of Future Time Perspective and Goal Orientation for Older Employees' Employability. Paper presented at the 15th biennial EARLI conference for research on learning and instruction. Munich.

Froehlich, D. E., Beausaert, S. A. J., \& Segers, M. S. R. (2012). Old and Out? A social network approach towards age, self-responsibility, and their effects on employability. Paper presented at the EARLI SIG 14. Antwerp. 